Prepared in cooperation with the Brunswick-Glynn County Joint Water and Sewer Commission and the Georgia Environmental Protection Division

\title{
Simulation of Groundwater Flow in the Brunswick Area, Georgia, for 2004 and 2015, and Selected Groundwater- Management Scenarios
}

\section{Scientific Investigations Report 2019-5035}

U.S. Department of the Interior U.S. Geological Survey 
Cover photograph: South end of Jekyll Island, Glynn County, Georgia. Photograph by Alan M. Cressler, U.S. Geological Survey. 


\section{Simulation of Groundwater Flow in the Brunswick Area, Georgia, for 2004 and 2015, and Selected Groundwater- Management Scenarios}

By Gregory S. Cherry

Prepared in cooperation with the Brunswick-Glynn County Joint Water and Sewer Commission and the Georgia Environmental Protection Division

Scientific Investigations Report 2019-5035 


\title{
U.S. Department of the Interior \\ DAVID BERNHARDT, Secretary
}

\author{
U.S. Geological Survey \\ James F. Reilly II, Director
}

U.S. Geological Survey, Reston, Virginia: 2019

For more information on the USGS - the Federal source for science about the Earth, its natural and living resources, natural hazards, and the environment-visit https://www.usgs.gov or call 1-888-ASK-USGS.

For an overview of USGS information products, including maps, imagery, and publications,

visit https://store.usgs.gov.

Any use of trade, firm, or product names is for descriptive purposes only and does not imply endorsement by the U.S. Government.

Although this information product, for the most part, is in the public domain, it also may contain copyrighted materials as noted in the text. Permission to reproduce copyrighted items must be secured from the copyright owner.

Suggested citation:

Cherry, G.S., 2019, Simulation of groundwater flow in the Brunswick area, Georgia, for 2004 and 2015, and selected groundwater-management scenarios: U.S. Geological Survey Scientific Investigations Report 2019-5035, 70 p., https://doi.org/10.3133/sir20195035. 


\section{Contents}

Acknowledgments ….....................................................................................................................ii

Abstract

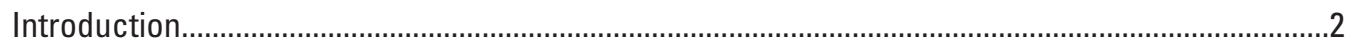

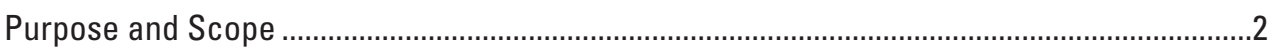

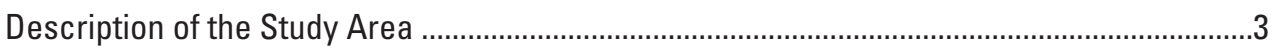

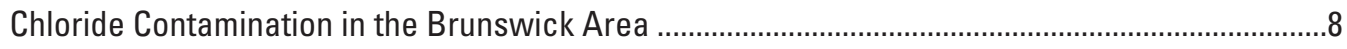

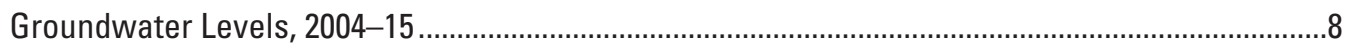

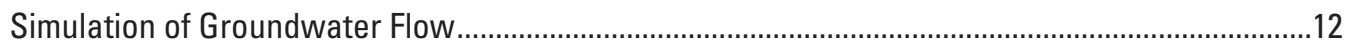

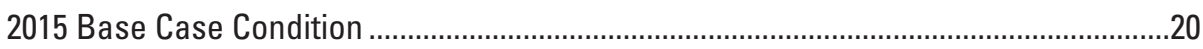

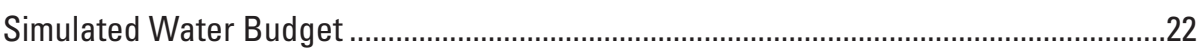

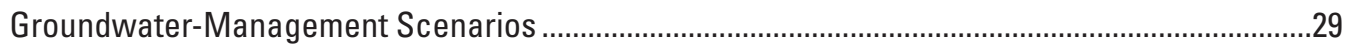

Scenario A .

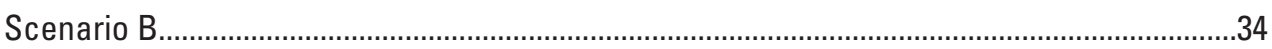

Scenario C .

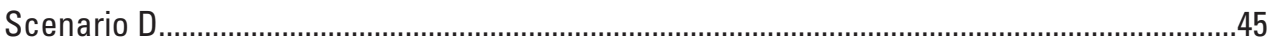

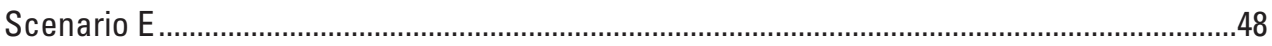

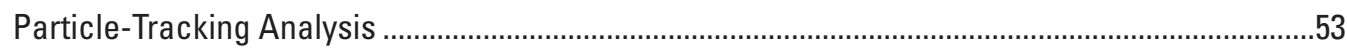

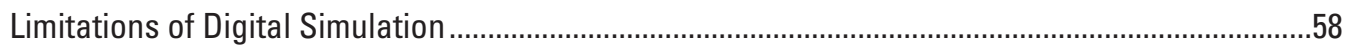

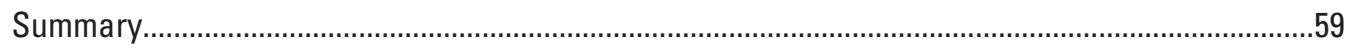

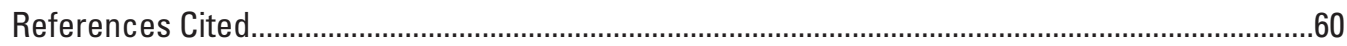

Appendix 1. Simulated and Observed Groundwater Levels, 2004 and 2015, for Wells Used in the Simulation of Groundwater Flow in the Brunswick/Glynn County Area of Georgia

Appendix 2. Particle Backtracking Summary for 2015 Base Case and Scenario C Simulations....67

\section{Figures}

1. Maps showing location of 24-county coastal Georgia area, model area, major structural features, and 250-milligram-per-liter chloride concentration isochlor for June 2001 and 2005 near Brunswick, Georgia.

2. Generalized correlation chart of geologic and hydrogeologic units in the Upper and Lower Coastal Plain and model layers used in the groundwater-flow model revised by Cherry (2015)

3. Generalized hydrogeologic cross section and groundwater-flow directions in the Brunswick/Glynn County area of Georgia

4. Map showing chloride concentration in the Upper Floridan aquifer in the area near downtown Brunswick, October 2015

5. Graph showing major groundwater pumpage from the Upper Floridan aquifer in the Brunswick/Glynn County area, Georgia, 1940-2015, and water levels in well 34H328, 1939-2013

6. Graph showing water-level of well $33 \mathrm{H} 133$ open to the upper water-bearing zone of the Upper Floridan aquifer in the Brunswick, Georgia, area, 2004-15.

7. Maps showing revised model grid of Cherry (2015) and major production wells, observation wells used during October 2015, and outline of the 2004 chloride plume for the Upper Floridan aquifer in the Brunswick, Georgia, area.....

8. Schematic diagram showing revised model layers and boundary conditions ................15 
9. Maps showing hydraulic-property geographic zones for the groundwater-flow model revised by Cherry (2015) near Brunswick/Glynn County, Georgia. .16

10. Maps showing simulated 2004 potentiometric surfaces and water-level residuals by model layer, Upper Floridan aquifer, Brunswick/Glynn County area, Georgia. .21

11. Maps showing simulated 2015 Base Case potentiometric surfaces and waterlevel residuals for model layer 7, upper water-bearing zone of the Upper Floridan aquifer, Glynn County and Brunswick area, Georgia......

12. Maps showing simulated water-level change from 2004 to 2015 Base Case for model layer 7, upper water-bearing zone of Upper Floridan aquifer in the Brunswick/Glynn County area in Georgia

13. Graphs showing simulated potentiometric profiles near the chloride plume in the Upper Floridan aquifer near downtown Brunswick, Georgia, during 2004 and 2015 Base Case

14. Schematic diagram showing simulated water budgets in Glynn County, Georgia, during 2004 and 2015 Base Case.

15. Map showing location of Brunswick-Glynn County Joint Water and Sewer Commission service areas and production wells used for the 2015 Base Case simulation and groundwater-management scenarios

16. Map showing Scenario A simulated potentiometric surface for model layer 7, upper water-bearing zone of the Upper Floridan aquifer, Brunswick/Glynn County area of Georgia

17. Map showing simulated water-level change from 2015 Base Case to Scenario A in model layer 7, upper water-bearing zone of the Upper Floridan aquifer, Brunswick/Glynn County area of Georgia...

18. Map showing Scenario B simulated potentiometric surface for model layer 7, upper water-bearing zone of the Upper Floridan aquifer, Brunswick/Glynn County area of Georgia

19. Maps showing simulated water-level change from 2015 Base Case to Scenario B in model layer 7, upper water-bearing zone of the Upper Floridan aquifer, Brunswick/Glynn County area of Georgia

20. Maps showing simulated 2015 Base Case and Scenario $C$ potentiometric surface for model layer 7, upper water-bearing zone of the Upper Floridan aquifer, Brunswick/Glynn County area of Georgia

21. Maps showing simulated water-level change from 2015 Base Case to Scenario $C$ in model layer 7, upper water-bearing zone of the Upper Floridan aquifer, Brunswick/Glynn County area of Georgia.

22. Graphs showing simulated potentiometric profiles near the chloride plume in the Upper Florida aquifer near downtown Brunswick, Georgia, for 2015 Base Case and Scenarios $C$ and $D$.

23. Maps showing simulated potentiometric surface for various percentages of industrial pumping in model layer 7, upper water-bearing zone of the Upper Florida aquifer, Brunswick/Glynn County, Georgia .

24. Maps showing simulated water-level change from 2015 Base Case to Scenario $C$ (0 percent); Scenario D1 (12.5 percent); Scenario D2 (25 percent); and Scenario D3 (50 percent) industrial pumping in model layer 7 , upper water-bearing zone of the Upper Floridan aquifer, Brunswick/Glynn County, Georgia

25. Maps showing Scenario E simulated potentiometric surface for model layer 7, upper water-bearing zone of the Upper Floridan aquifer, Brunswick/Glynn County, Georgia 
26. Maps showing simulated water-level change from 2015 Base Case to Scenario E in model layer 7, upper water-bearing zone of the Upper Floridan aquifer, Brunswick/Glynn County, Georgia..

27. Map showing particle backtracking pathlines from the 2015 Base Case simulation with particles placed in Brunswick-Glynn County Joint Water and Sewer Commission production wells located near the chloride plume in downtown Brunswick, Georgia.

28. Map showing particle backtracking pathlines from the Scenario $C$ simulation with particles placed in Brunswick-Glynn County Joint Water and Sewer Commission production wells located near the chloride plume in downtown Brunswick, Georgia.

1-1. Maps showing location of wells used for 2004 and 2015 simulations in Glynn County and Brunswick, Georgia.

\section{Tables}

1. Annual precipitation during 2004-2015 for University of Georgia weather network stations located in southeastern Georgia

2. Water-level measurements taken during June 2004 and October 2015 and observed water-level change from 2004 to 2015 in the Brunswick/Glynn County area, Georgia .

3. Horizontal and vertical hydraulic conductivity values assigned to hydraulicproperty geographic zones for the groundwater-flow model revised by Cherry (2015) in the Glynn County area and adjacent counties in Georgia

4. Calibration statistics for simulated heads for 2004 conditions in Glynn County, Georgia

5. Calibration statistics for simulated heads for 2015 Base Case in Glynn County, Georgia

6. Simulated and observed groundwater levels and water-level changes, 2004 and 2015 Base Case, for model layer 7, upper water-bearing zone of the Upper Floridan aquifer in the Brunswick/Glynn County area, Georgia

7. Simulated head difference and horizontal potentiometric gradients for 2004 and 2015 Base Case along profiles $A-A^{\prime}, B-B^{\prime}, C-C^{\prime}, D-D^{\prime}$, and $E-E^{\prime}$ in the upper water-bearing zone of the Upper Floridan aquifer in the downtown area of Brunswick, Georgia.

8. Flow-budget components for 2004 and 2015 Base Case in the Brunswick/Glynn County area of Georgia.

9. Simulated pumping at selected production wells for the 2015 Base Case simulation and model Scenarios A-E.

10. Simulated groundwater levels for 2015 Base Case, Scenarios A, B, C, and D1D3 at selected wells for model layer 7, upper water-bearing zone of the Upper Floridan aquifer, Brunswick/Glynn County area of Georgia ....

11. Simulated head difference and horizontal potentiometric gradients for 2015 Base Case and Scenarios $\mathrm{A}, \mathrm{B}, \mathrm{C}, \mathrm{D} 1, \mathrm{D} 2$, and $\mathrm{D} 3$ along profiles $A-A^{\prime}, B-B^{\prime}, C-C^{\prime}$, $D-D^{\prime}$, and $E-E^{\prime}$ in the upper water-bearing zone of the Upper Floridan aquifer (model layer 7) in the downtown Brunswick area of Georgia.

12. Results of particle backtracking from Brunswick-Glynn County Joint Water and Sewer Commission production wells toward upgradient areas for 2015 Base Case simulation in the downtown Brunswick area of Georgia. 
13. Results of particle backtracking from Brunswick-Glynn County Joint Water and Sewer Commission production wells toward upgradient areas for Scenario C simulation in the downtown Brunswick area of Georgia

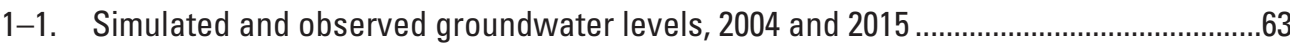

2-1. Particle backtracking summary for 2015 Base Case and Scenario $C$ simulations..........67

\section{Conversion Factors}

U.S. customary units to International System of Units

\begin{tabular}{|c|c|c|}
\hline Multiply & By & To obtain \\
\hline \multicolumn{3}{|c|}{ Length } \\
\hline inch (in.) & 2.54 & centimeter $(\mathrm{cm})$ \\
\hline foot $(\mathrm{ft})$ & 0.3048 & meter $(\mathrm{m})$ \\
\hline mile (mi) & 1.609 & kilometer (km) \\
\hline \multicolumn{3}{|c|}{ Area } \\
\hline square mile $\left(\mathrm{mi}^{2}\right)$ & 259.0 & hectare (ha) \\
\hline square mile $\left(\mathrm{mi}^{2}\right)$ & 2.590 & square kilometer $\left(\mathrm{km}^{2}\right)$ \\
\hline \multicolumn{3}{|c|}{ Volume } \\
\hline million gallons (Mgal) & 3,785 & cubic meter $\left(\mathrm{m}^{3}\right)$ \\
\hline \multicolumn{3}{|c|}{ Flow rate } \\
\hline inch per year (in/yr) & 2.54 & centimeters per year (cm/yr) \\
\hline cubic foot per second $\left(\mathrm{ft}^{3} / \mathrm{s}\right)$ & 0.02832 & cubic meter per second $\left(\mathrm{m}^{3} / \mathrm{s}\right)$ \\
\hline cubic foot per day $\left(\mathrm{ft}^{3} / \mathrm{d}\right)$ & 0.02832 & cubic meter per day $\left(\mathrm{m}^{3} / \mathrm{d}\right)$ \\
\hline foot per day (ft/d) & 0.3048 & meter per day $(\mathrm{m} / \mathrm{d})$ \\
\hline foot per year (ft/yr) & 0.3048 & meter per year (m/yr) \\
\hline million gallons per day $(\mathrm{Mgal} / \mathrm{d})$ & 0.04381 & cubic meter per second $\left(\mathrm{m}^{3} / \mathrm{s}\right)$ \\
\hline \multicolumn{3}{|c|}{ Hydraulic conductivity } \\
\hline foot per day (ft/d) & 0.3048 & meter per day $(\mathrm{m} / \mathrm{d})$ \\
\hline \multicolumn{3}{|c|}{ Transmissivity* $^{*}$} \\
\hline foot squared per day $\left(\mathrm{ft}^{2} / \mathrm{d}\right)$ & 0.0929 & meter squared per day $\left(\mathrm{m}^{2} / \mathrm{d}\right)$ \\
\hline \multicolumn{3}{|c|}{ Potentiometric gradient } \\
\hline foot per mile (ft/mi) & 0.1894 & meter per kilometer $(\mathrm{m} / \mathrm{km})$ \\
\hline
\end{tabular}

Temperature in degrees Fahrenheit $\left({ }^{\circ} \mathrm{F}\right)$ may be converted to degrees Celsius $\left({ }^{\circ} \mathrm{C}\right)$ as ${ }^{\circ} \mathrm{C}=\left({ }^{\circ} \mathrm{F}-32\right) / 1.8$.

\section{Datum}

Vertical coordinate information is referenced to the National Geodetic Vertical Datum of 1929 (NGVD 29) or the North American Vertical Datum of 1988 (NAVD 88).

Horizontal coordinate information is referenced to North American Datum of 1983 (NAD 83). Altitude, as used in this report, refers to distance above the vertical datum. 


\section{Supplemental Information}

*Transmissivity: The standard unit for transmissivity is cubic foot per day per square foot times foot of aquifer thickness $\left[\left(\mathrm{ft}^{3} / \mathrm{d}\right) / \mathrm{ft}^{2}\right] \mathrm{ft}$. In this report, the mathematically reduced form, foot squared per day $\left(\mathrm{ft}^{2} / \mathrm{d}\right)$, is used for convenience.

Concentrations of chemical constituents in water are given in milligrams per liter (mg/L).

\section{Georgia Well-Identification System}

Wells described in this report are assigned a well identifier according to a system based on the index of U.S. Geological Survey (USGS) 7.5-minute topographic maps of Georgia. Quadrangles shown on the map of Georgia have been assigned a two- to three-digit number and letter designation (for example, $07 \mathrm{H}$ ) beginning at the southwestern corner of the State. Numbers increase sequentially eastward, and letters advance alphabetically northward. Quadrangles in the northern part of the State are designated by double letters: AA follows Z, and so forth. The letters "I," " 0 ," “II," and " 00 " are not used. Wells inventoried in each quadrangle are numbered consecutively, beginning with 001 . Thus, the fourth well inventoried in the $34 \mathrm{H}$ quadrangle is designated 34H004. In the USGS National Water Information System (NWIS) database, this information is found in the "Site Name" field.

\section{Abbreviations}

$\begin{array}{ll}\text { BGJWSC } & \text { Brunswick-Glynn County Joint Water and Sewer Commission } \\ \text { FLETC } & \text { Federal Law Enforcement Training Center } \\ \text { GaEPD } & \text { Georgia Environmental Protection Division } \\ \text { LFA } & \text { Lower Floridan aquifer } \\ \text { LWBZ } & \text { lower water-bearing zone } \\ \text { NWIS } & \text { National Water Information System } \\ \text { RMSE } & \text { root-mean-square error } \\ \text { UFA } & \text { Upper Floridan aquifer } \\ \text { USGS } & \text { U.S. Geological Survey } \\ \text { UWBZ } & \text { upper water-bearing zone } \\ \text { WRMAC } & \text { Water Resources Management Advisory Committee }\end{array}$




\section{Acknowledgments}

The authors thank Billy Simmons of the Brunswick-Glynn County Joint Water and Sewer Commission and James Kennedy, State Geologist, Georgia Environmental Protection Division, for support of ongoing water-resources investigations in the Glynn County area. During early stages of model development, members of the Glynn County Water Resources Management Advisory Committee (WRMAC) provided technical guidance, including development of watermanagement scenarios for evaluation by the revised model. Appreciation goes to WRMAC members Bobby Palmer, Chair, private citizen; Glenn Hoffman, Vice Chair, Hercules Inc.; Dan McFee, City of Brunswick; Keith Morgan, Brunswick-Glynn County Joint Water and Sewer Commission; John Day, Jekyll Island Authority; Kenneth Hase, Brunswick Cellulose Inc.; Jim Benson, private citizen; William Francis, private citizen; Dick Johnston, private citizen; Hal Hart, private citizen; David Kyler, private citizen; and Milton Peterman, private citizen.

Groundwater-use data were updated to 2015 thanks to the assistance of Julie Dickens, Brunswick Cellulose Inc., and Maurice Gray, Pinova Inc. Thanks are extended to Bradford Price, Brunswick Cellulose Inc., who provided coordinates and well information on the new Brunswick Cellulose production well.

Thanks are also extended to Michael Peck, Michael Hamrick, and Gary Holloway,

U.S. Geological Survey (USGS), who collected water-level data during the October 2015 synoptic survey, and to Jaime Painter, USGS, who provided assistance in the development of model input and display of model results using geographic information system techniques. 


\title{
Simulation of Groundwater Flow in the Brunswick Area, Georgia, for 2004 and 2015, and Selected Groundwater- Management Scenarios
}

\author{
By Gregory S. Cherry
}

Abstract

The Upper Floridan aquifer (UFA) is the principal water source for industrial and public supply in Glynn County, Georgia. Wells in active pumping centers that tap the UFA for industries near the city of Brunswick have created an upward hydraulic-head gradient in the Floridan aquifer system, which has allowed high chloride (saline) groundwater from the Fernandina permeable zone of the Lower Floridan aquifer (LFA) to migrate upward into freshwater zones. Chloride concentrations of more than 250 milligrams per liter - the State and Federal secondary drinking-water standard - have been measured in a 2-square-mile area near downtown Brunswick.

An existing regional U.S. Geological Survey modular finite-difference groundwater-flow model (MODFLOW-2000) was modified using greater horizontal and vertical resolution to enable more detailed simulation of the effects of pumping in the vicinity of chloride contamination. Modifications to the regional model consisted of (1) limiting grid size to a maximum of 500 feet $(\mathrm{ft})$ per side in the vicinity of the chloride plume; (2) representing the upper and lower Brunswick aquifers with distinct model layers; (3) similarly, representing upper and lower water-bearing zones of the UFA with distinct model layers in Glynn and Camden Counties, Ga.; and (4) establishing new hydraulic-property geographic zones in the UFA within Glynn County. The revised groundwater-flow model was calibrated to steady-state conditions that were assumed to exist during 2000 and 2004. The calibration and framework of the revised groundwaterflow model were documented in a separate report. For the current study, steady-state conditions were calibrated using October 2015 pumping rates in the Brunswick/Glynn County area as a 2015 Base Case. The 2015 Base Case simulation was used as the basis to evaluate seven groundwater-management scenarios in the Brunswick/Glynn County area.

Seven groundwater management-scenarios were developed on the basis of short- and long-term groundwater-use projections for the UFA in the Brunswick/ Glynn County area. Scenarios A and B simulated additional pumping in the upper water-bearing zone (UWBZ) of the UFA at existing public-supply wells located near a chloride plume and planned public-supply wells to be constructed north of downtown Brunswick. Scenario C simulated a shutdown at Brunswick Cellulose Inc. and Pinova Inc. and the resulting deactivation of nine production wells, with a combined total pumping of 31.3 million gallons per day (Mgal/d) for the 2015 Base Case simulation. Scenario D (three scenarios) simulated 12.5, 25, and 50 percent (designated Scenarios D1, $\mathrm{D} 2$, and D3) of the total pumping of $31.3 \mathrm{Mgal} / \mathrm{d}$ at Brunswick Cellulose and Pinova. The objective of Scenario D was to determine pumping rates that may reverse groundwaterflow directions toward the Brunswick Cellulose well field and potentially allow groundwater with higher chloride concentration to migrate toward nearby public-supply wells. Scenario E simulated an additional pumping of $5 \mathrm{Mgal} / \mathrm{d}$ from the UWBZ of the UFA at a recently constructed production well within the Brunswick Cellulose well field.

Backward particle-tracking (MODPATH) analysis in public-supply wells located just outside the chloride plume to the north shows that predominant groundwater-flow directions are from the northeast toward the Brunswick Cellulose well field. The analysis covered 20- and 50-year periods for the 2015 Base Case and Scenario C simulations with 100 percent of backtracked particles remaining in the UWBZ and lower water-bearing zone of the UFA. Groundwater-flow directions are characterized by some vertical movement and dominant horizontal movement away from the chloride plume in the northern Brunswick area. For the 2015 Base Case simulation, the mean rate of particle movement ranged from 268 to 413 feet per year. For the Scenario C simulation, the mean rate of particle movement ranged from 89 to 182 feet per year with 50 percent of particles migrating from the chloride plume area. The rate of particle movement is influenced most by the horizontal hydraulic-head gradient in the UWBZ of the UFA. 
The revised groundwater-flow model is subject to the limitations documented in the original model. In addition, the values used for the specified-head boundaries in the Floridan aquifer system for the 2004 calibrated model were based on the sparse data available and were not changed for the 2015 update to the model. These model boundaries control 80 percent of the inflows and about 60 percent of the outflows. Composite-scaled sensitivities of the model parameters indicate the revised model is most sensitive to pumping rates, followed by the horizontal hydraulic conductivity in the UFA for zones along coastal Georgia.

\section{Introduction}

In the Brunswick/Glynn County area of Georgia, saltwater intrusion has been contaminating the Upper Floridan aquifer (UFA) for more than 50 years. Currently (2015) within an area covering several square miles in downtown Brunswick, the aquifer yields water that has a chloride concentration greater than 2,000 milligrams per liter (mg/L), well above the $250-\mathrm{mg} / \mathrm{L}$ State and Federal secondary drinking-water standard (Georgia Environmental Protection Division, 1997; U.S. Environmental Protection Agency, 2000). Saltwater contamination has constrained further development of the UFA in the Brunswick area, prompting interest in the development of alternative sources of water supply primarily from the shallower surficial and Brunswick aquifer systems. In the downtown Brunswick area, the Georgia Environmental Protection Division (GaEPD) has limited further development of the UFA to areas outside the chloride plume and development must be performed in a way that will minimize migration of groundwater with high-chloride concentrations and maintain hydraulic-head gradients toward active pumping centers in the area. The U.S. Geological Survey (USGS), in cooperation with the Brunswick-Glynn County Joint Water and Sewer Commission (BGJWSC) and the GaEPD, revised an existing groundwater model to simulate the effects of pumping on the migration of high-chloride water in the Brunswick/Glynn County area, thereby providing scientific information essential for managing water resources in the area.

An existing regional groundwater-flow model (Payne and others, 2005) was modified by Cherry (2015) to greater horizontal and vertical resolution to enable more detailed simulation of the effects of pumping in the vicinity of the chloride plume. Modifications to the regional model include (1) reducing grid dimensions to a minimum of 500 feet (ft) per side in the vicinity of the chloride plume, (2) subdividing the Brunswick aquifer system into the upper and lower Brunswick aquifers, (3) subdividing the UFA into the upper and lower water-bearing zones (UWBZ and LWBZ, respectively), and (4) establishing new hydraulic-property geographic zones in the UFA to improve model calibration in the Brunswick/Glynn
County area. The modified steady-state model (Cherry, 2015) has been updated to include October 2015 pumping rates presented in this report as a 2015 Base Case simulation in the Brunswick/Glynn County area and calibrated using local water-level measurements from observation wells to confirm simulated response to changing pumping rates. The 2015 Base Case simulation was compared to five groundwatermanagement scenarios whereby pumping in existing and hypothetical wells was adjusted in varying amounts. Information from these scenarios can be used by water managers in the area to make informed decisions.

\section{Purpose and Scope}

The purpose of this report is to document the simulation of groundwater flow in the Brunswick/Glynn County area during October 2015 and evaluate seven groundwatermanagement scenarios using the revised groundwater-flow model, which represents a 2015 Base Case simulation. The original regional model and the revised groundwaterflow model used a previously published application of the USGS modular finite-difference computer program (MODFLOW-2000; Harbaugh and others, 2000). The original regional model by Payne and others (2005) was developed to simulate regional groundwater flow along the Georgia coast in the Brunswick and Floridan aquifer systems during 1980 and 2000. The purpose of the groundwater-flow model revised by Cherry (2015) was to simulate the steady-state effect of changing pumping rates during 2000 and 2004 on groundwater levels and evaluate changes in hydraulichead gradients near pumping centers in the Brunswick area. Revisions to the original model include (1) increased spatial resolution near the downtown Brunswick, Ga., area, (2) additional hydraulic-property geographic zones in the UFA near the Brunswick/Glynn County area, (3) subdivision of the Brunswick aquifer system, and (4) subdivision of the Floridan aquifer system into separate model layers to better represent the local hydrogeology.

This report describes revisions to the groundwater-flow model by Cherry (2015) for the Brunswick/Glynn County area, including calibration of simulated heads to observed heads (residuals, simulated heads minus observed heads). The simulated heads determine general groundwater-flow directions and relative rates of movement, and selected potentiometric profiles provide an assessment of horizontal hydraulic-head gradients near downtown Brunswick. The adjusted 2015 Base Case steady-state simulation was used as a comparison to simulated heads and water budgets for five groundwater-management scenarios. Simulated particletracking analyses can be used to identify and calculate time of travel from pumping centers backward toward recharge areas. Model input and output data generated during this study are available as a USGS data release (Cherry, 2019). 


\section{Description of the Study Area}

Glynn County is located in the Coastal Plain physiographic province on Georgia's Atlantic Coast about 80 miles (mi) south of Savannah, Ga., and about $60 \mathrm{mi}$ north of Jacksonville, Florida (fig. 1). The county encompasses about 422 square miles $\left(\mathrm{mi}^{2}\right)$ and is bordered on the north by the Altamaha River, which empties into the Atlantic Ocean north of St. Simons Island. The Little Satilla River forms the boundary to the south, and the county is bordered by Wayne and Brantley Counties to the west. Altitudes in Glynn County range from $0 \mathrm{ft}$ along the coast to as high as $67 \mathrm{ft}$ (above North American Vertical Datum of 1988) in the southwestern part of the county.

The city of Brunswick is located on a peninsula in Glynn County and encompasses about $50 \mathrm{mi}^{2}$. The city is bordered by St. Simons and Jekyll Islands to the east and by the Brunswick and Little Satilla Rivers to the west and south, respectively (fig. 1B). Both rivers form tidally influenced estuaries in the Brunswick area.

In 2015 the population of Glynn County was 83,579 (U.S. Census Bureau, 2017). The primary population center of Glynn County is the city of Brunswick, and a secondary population center has developed in the southern part of St. Simons Island. Outside these urban areas, land use in Glynn County is a mixture of forest, grazed woodland, marsh, and swampland.

Coastal Plain sediments consist of consolidated to unconsolidated layers of sand and clay, to semiconsolidated to dense layers of limestone and dolomite, which range in age from Late Cretaceous to Holocene. In general, these hydrogeologic units have been divided into aquifers and confining units on the basis of their wateryielding characteristics, with relatively high permeability layers forming aquifers and low-permeability layers forming confining units (fig. 2). These sedimentary units unconformably overlie igneous, metamorphic, and sedimentary rocks of Paleozoic to Mesozoic age and reach a maximum thickness of 5,500 ft just south of Glynn County in Camden County (Wait and Davis, 1986). The thickness of sedimentary units varies and is influenced by major structural features in the area, such as the Southeast Georgia Embayment, Beaufort Arch, and Gulf Trough (fig. 1A). Another feature, less prominent than the Gulf Trough, is the Satilla Line, which is a postulated hydrologic boundary identified by GaEPD that could influence groundwater flow in the UFA. The feature's existence is based on a change in the configuration of the potentiometric surface of the UFA, and by linear changes depicted on aeromagnetic, aeroradioactivity, gravity, and isopach maps; however, its geologic origin and nature are unknown. In general, the surficial and Brunswick aquifer systems are composed predominantly of sands, silts, and minor limestone with transmissivities ranging from 14 to 6,000 feet squared per day $\left(\mathrm{ft}^{2} / \mathrm{d}\right.$; Clarke, 2003). The highest transmissivity values for both aquifer systems were reported near the Southeast Georgia Embayment where the units reach a maximum thickness. In the Glynn County area and outside this feature, the Brunswick aquifer system thins, or is discontinuous, and has a greater percentage of fine-grained sediments (Clarke, 2003). The Brunswick aquifer system is separated from the underlying Floridan aquifer system by a confining unit consisting of layers of silty clay and dense phosphatic dolomite of Oligocene age (Clarke, 2003).

The primary focus of the current report is the Floridan aquifer system, which consists of the UFA and Lower Floridan aquifer (LFA), composed of mostly Paleocene to Oligocene carbonate rocks that locally include Upper Cretaceous rocks (Miller, 1986; Krause and Randolph, 1989; fig. 2). The Floridan aquifer system extends from coastal areas in southeastern South Carolina, westward across the coastal plain of Georgia and Alabama, and southward, encompassing Florida. The thickness of the Floridan aquifer system in the model area varies from less than $100 \mathrm{ft}$ in aquifer outcrop areas of South Carolina to about 1,700 ft near the city of Brunswick (fig. 3; Williams and Kuniansky, 2015). The UFA is highly productive and consists of Eocene to Oligoceneage limestone and dolomite (Clarke and others, 1990). In the Brunswick/Glynn County area, Wait and Gregg (1973) identified upper and lower water-bearing zones (UWBZ and LWBZ, respectively) within the UFA, with the upper zone having higher production as indicated by pumping data from a well that tapped both zones. The UFA is underlain by a confining unit of dense recrystallized limestone and dolomite of middle to late Eocene age that hydraulically separates the UFA from the LFA by varying degrees. Locally in the Brunswick area, the confining unit is breached by fractures or solution openings that enhance the exchange of water between the UFA and LFA (Krause and Randolph, 1989; Maslia and Prowell, 1990). The LFA is composed mainly of dolomitic limestone of early and middle Eocene age; at the city of Brunswick, however, the LFA includes highly permeable limestone of Paleocene and Late Cretaceous age (Krause and Randolph, 1989). In southeastern Georgia and northeastern Florida, the LFA includes a saline water-bearing unit known as the Fernandina permeable zone, which is deeply buried, cavernous, and highly permeable (Krause and Randolph, 1989). The Fernandina permeable zone is present at a depth of about 2,100 ft in a USGS test well (TW-26) on Colonels Island (fig. 1B). The test well is $2,727 \mathrm{ft}$ deep and is important in the Brunswick area because it indicates the local source of saline water in the Fernandina permeable zone (Jones and others, 2002).

Glynn County has a warm temperate and fully humid climate, with warm summers (Kottek and others, 2006). The average temperature for the climate-normal period of 19812010 was 68.1 degrees Fahrenheit based on data compiled at St. Simons Island, Ga. (National Oceanic and Atmospheric Administration, 2014). Mean-annual precipitation for the same period is 45.0 inches, with the heaviest rainfall occurring during the months of June, August, and September. Glynn County is located in the central subarea of the 24-county coastal area designated by the GaEPD, which subdivided the area into northern, central, and southern subareas to facilitate water-management practices (fig. $1 A$ ). 
$\boldsymbol{A}$

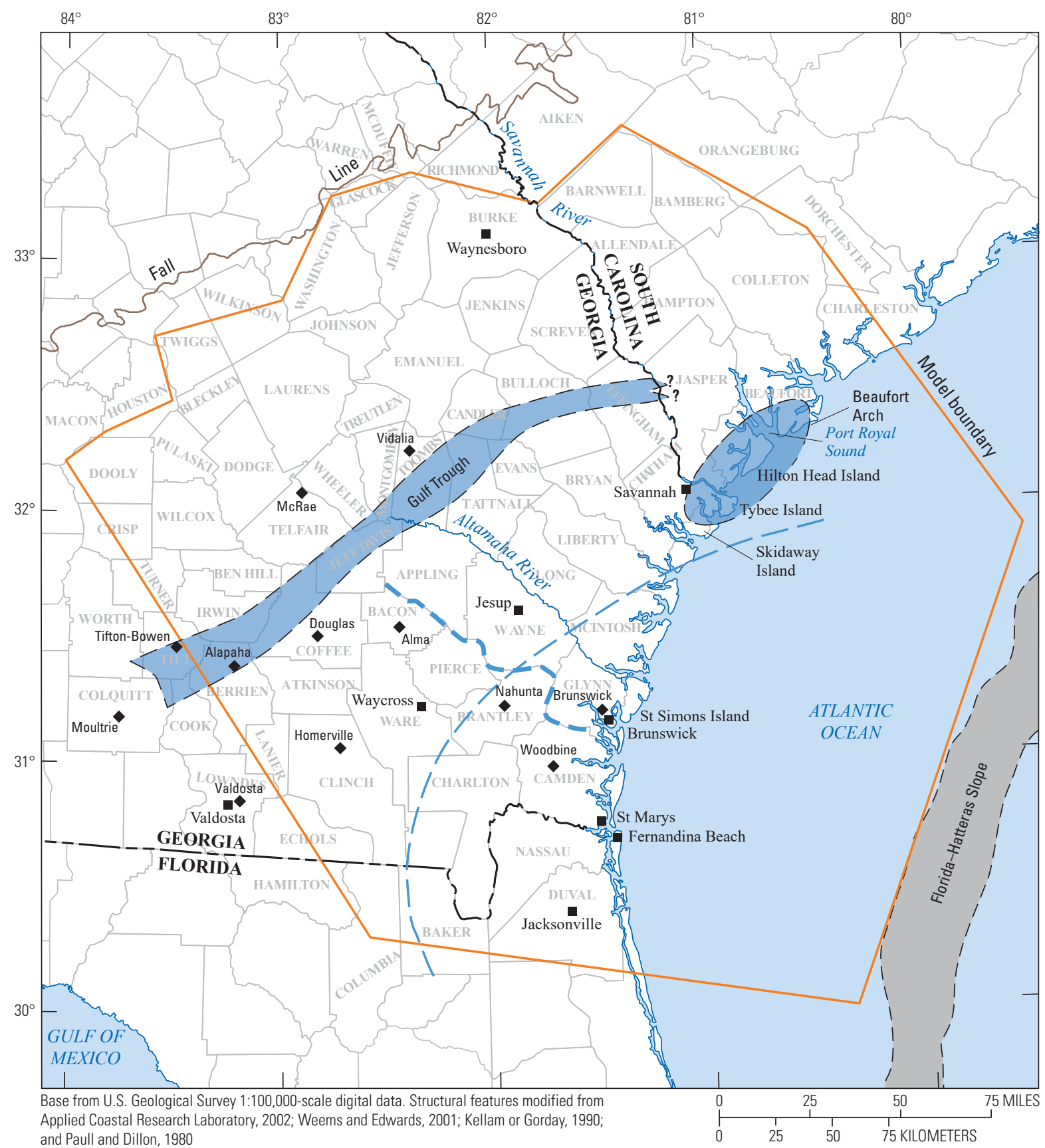

and Paull and Dillon, 1980

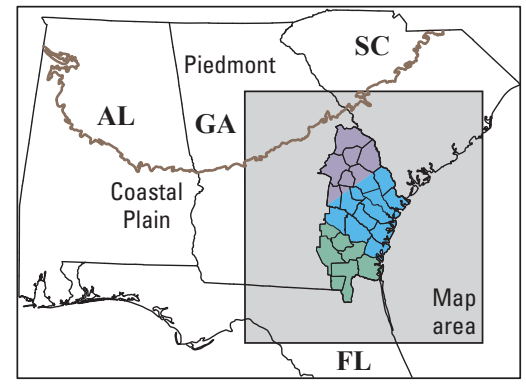

EXPLANATION

24-county coastal Georgia area as identified by the Georgia Environmental Protection Division
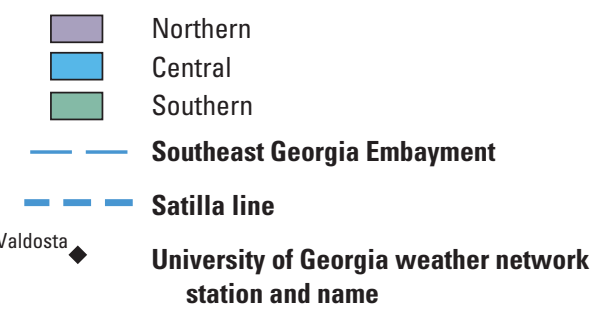

Figure 1. Maps showing location of $(A)$ 24-county coastal Georgia area, model area, major structural features, and (B) 250-milligramper-liter chloride concentration isochlor for June 2001 and 2005 near Brunswick, Georgia. 


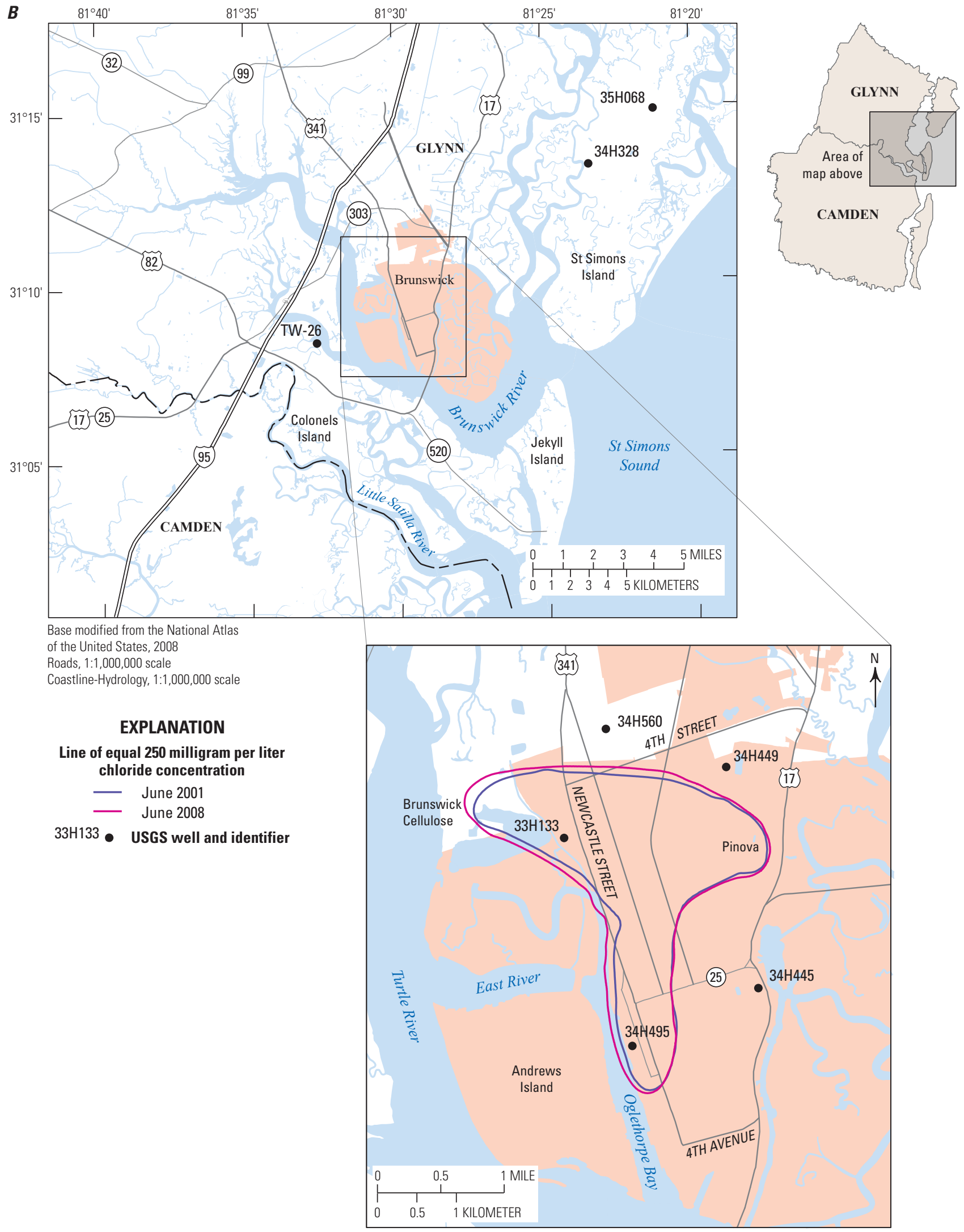

Figure 1. - Continued 


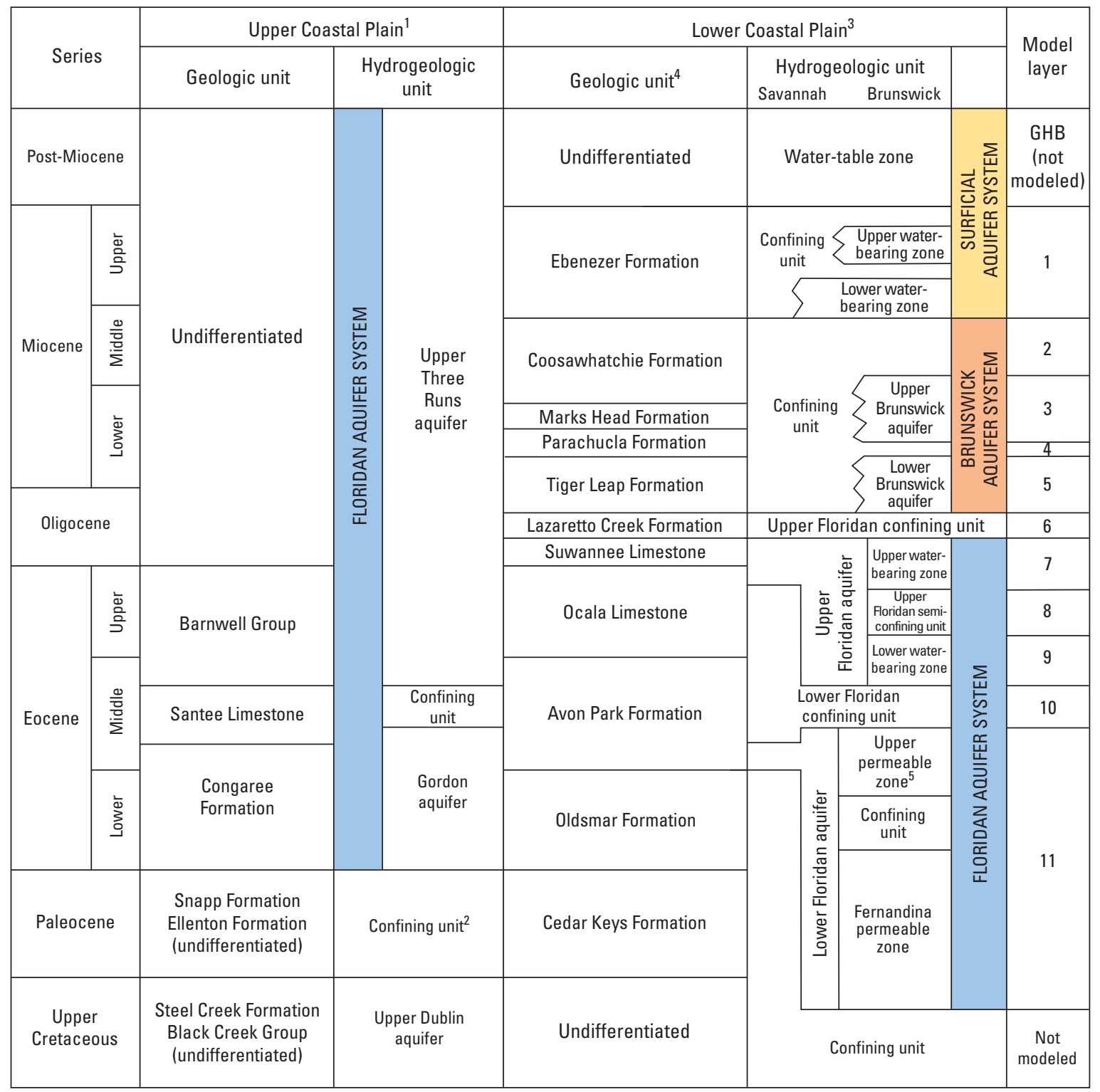

${ }^{1}$ Modified from Falls and others, 1997.

${ }^{2}$ In local areas includes Millers Pond aquifer.

${ }^{3}$ Modified from Randolph and others, 1991; Clarke and Krause, 2000.

${ }^{4}$ Modified from Randolph and others, 1991; Weems and Edwards, 2001.

${ }^{5}$ Clarke and others, 1990; Krause and Randolph, 1989.

Figure 2. Generalized correlation chart of geologic and hydrogeologic units in the Upper and Lower Coastal Plain and model layers used in the groundwater-flow model revised by Cherry (2015). 


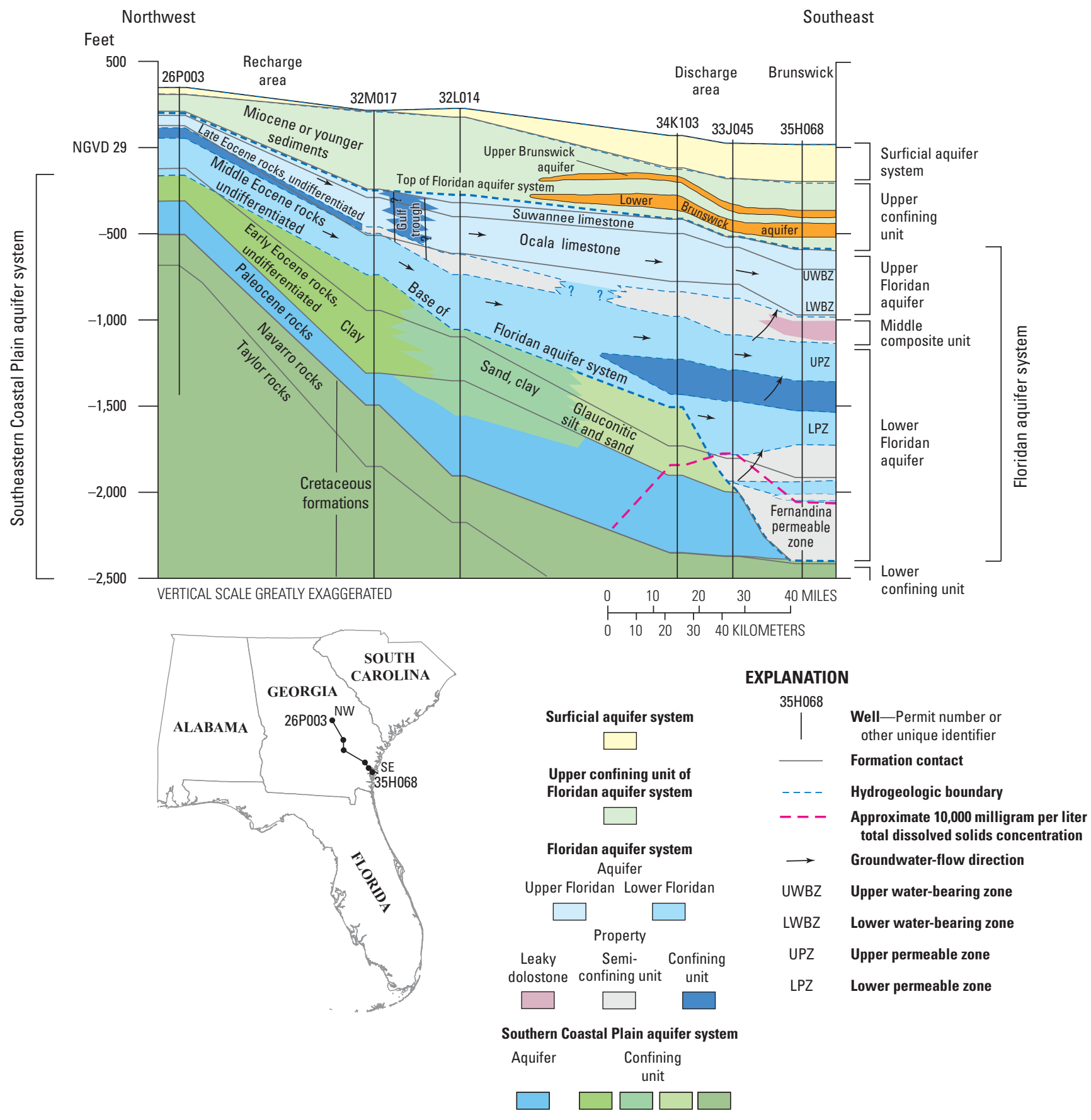

Figure 3. Generalized hydrogeologic cross section and groundwater-flow directions in the Brunswick/Glynn County area of Georgia. 


\section{Chloride Contamination in the Brunswick Area}

In the Brunswick area, saline water has been contaminating the UFA since the late 1950s and has constrained development of the aquifer (Wait, 1965). Analyses of water samples collected in 2015 showed chloride concentrations greater than or equal to $250 \mathrm{mg} / \mathrm{L}$ covered a 2-mi ${ }^{2}$ area near downtown Brunswick. Chloride concentrations within the area exceeded 2,000 mg/L (fig. 4; Cherry and Peck, 2017), well above the 250-mg/L State and Federal secondary drinking-water standard (Georgia Environmental Protection Division, 1997; U.S. Environmental Protection Agency, 2000).

Since the late 1950s, the USGS has collected water samples from the UFA in the Brunswick area and documented increasing chloride concentrations in response to increased groundwater withdrawals. Extensive pumping in the UFA resulted in lowered water levels and an upward hydraulichead gradient between the saline portions of the Fernandina permeable zone and the typically freshwater of the UFA (fig. 5). Saline water is most likely entering the UFA through localized, vertically oriented conduits of relatively high permeability and moving laterally in response to pumping within the UWBZ. Acoustic televiewer images from test well 33H188 (TW-26) provide evidence of features that appear to be high-angle fault and (or) fracture zones at a depth near 2,475 ft (Jones and others, 2002). The chloride concentration of seawater is about $20,000 \mathrm{mg} / \mathrm{L}$, and the water taken from the bottom of the Fernandina permeable zone at well $33 \mathrm{H} 188$ in 1982 was about 30,000 mg/L (Krause and Randolph, 1989). Discrete water samples collected during the drilling of well 34H495, located in the southern part of the chloride plume, in July 2000 at a depth of 2,243 ft indicate a chloride concentration of $18,000 \mathrm{mg} / \mathrm{L}$ (Falls and others, 2005). The chloride plume has stabilized in recent years, most likely because local horizontal hydraulic-head gradients have been maintained and groundwater withdrawals by local industry and by regional groundwater users over the coastal region have decreased (Cherry, 2007; Cherry and Clarke, 2008; Cherry and others, 2010 and 2011; Cherry and Peck, 2017).

\section{Groundwater Levels, 2004-15}

Groundwater levels vary seasonally and are affected by precipitation, evapotranspiration, and pumping. Groundwater levels generally are highest in the winter through early spring when evapotranspiration is lowest and irrigation withdrawals are minimal; groundwater levels generally are lowest during summer and fall when evapotranspiration and pumping rates are highest. In the Brunswick area, a water-level hydrograph for well $33 \mathrm{H} 133$ (fig. $1 B$ ), open to the UWBZ of the UFA, shows water-level fluctuations during 2004-15 (fig. 6). The hydrograph indicates relatively stable water levels during 2004-05, followed by a downward trend during 2006-07, and then a general upward trend during 2008-15. Rainfall data from 12 stations located in the southeastern part of Georgia indicate the driest years occurred during 2006, 2007, and 2011, with annual rainfall totals below 40 inches (University of Georgia Weather Network, 2018; table 1). The wettest year occurred during 2009 with mean annual rainfall of 57.3 inches; above-normal rainfall characterized the period during 2013-15. The peaks in the water-level hydrograph over the 12-year period of record represent rapid water-level recovery during partial shutdowns of the Brunswick Cellulose well field, which generally occur once a year.

In the Brunswick/Glynn County area, discrete waterlevel measurements from seven observation wells open to the Brunswick aquifer system indicate a general water-level rise from 2004 to 2015 (table 2). Overall, changes in water levels from 2004 to 2015 ranged from $-1.84 \mathrm{ft}$ (well 34H437) to $8.23 \mathrm{ft}$ (well 34J077), with an average increase of $2.35 \mathrm{ft}$ in the upper Brunswick aquifer and $1.53 \mathrm{ft}$ in the lower Brunswick aquifer. Observation wells 34J077, 34J080, and 34J081 are located near active production wells open to the upper and lower Brunswick aquifers, and water levels are likely influenced by local pumping.

In the UWBZ of the UFA, discrete water-level measurements made in 14 wells during 2004 and 2015 indicate water-level declines and rises ranging from -0.62 to $5.22 \mathrm{ft}$, with an average water-level rise of $3.11 \mathrm{ft}$ (table 2). Water levels in well 33H133 show a water-level rise during 2004 to 2015 of $4.43 \mathrm{ft}$, with more than $12 \mathrm{ft}$ of the rise occurring from August 2007 to October 2015 (fig. 6). Waterlevel observations for the LWBZ of the UFA are sparse but indicate water-level rises consistent with the UWBZ, with well $33 \mathrm{H} 154$ indicating a water-level increase of $26.0 \mathrm{ft}$. This well is located near the Brunswick Cellulose well field, and increases in water levels are influenced by decreases in pumping from the LWBZ of the UFA.

In the LFA, discrete water-level measurements made in three wells from 2004 to 2015 indicate water-level rises ranging from 2.00 to $4.59 \mathrm{ft}$. These water-level changes are consistent with water-level rises in the Brunswick aquifer system and the UWBZ and LWBZ of the UFA. During the previous calibration period from 2000 to 2004, water-level recoveries were observed in the Brunswick and Floridan aquifer systems because of the shutdown of the Durango Paper Company mill located in St. Marys, Camden County, Ga., during 2002 (fig. 1; Peck and others, 2005). 


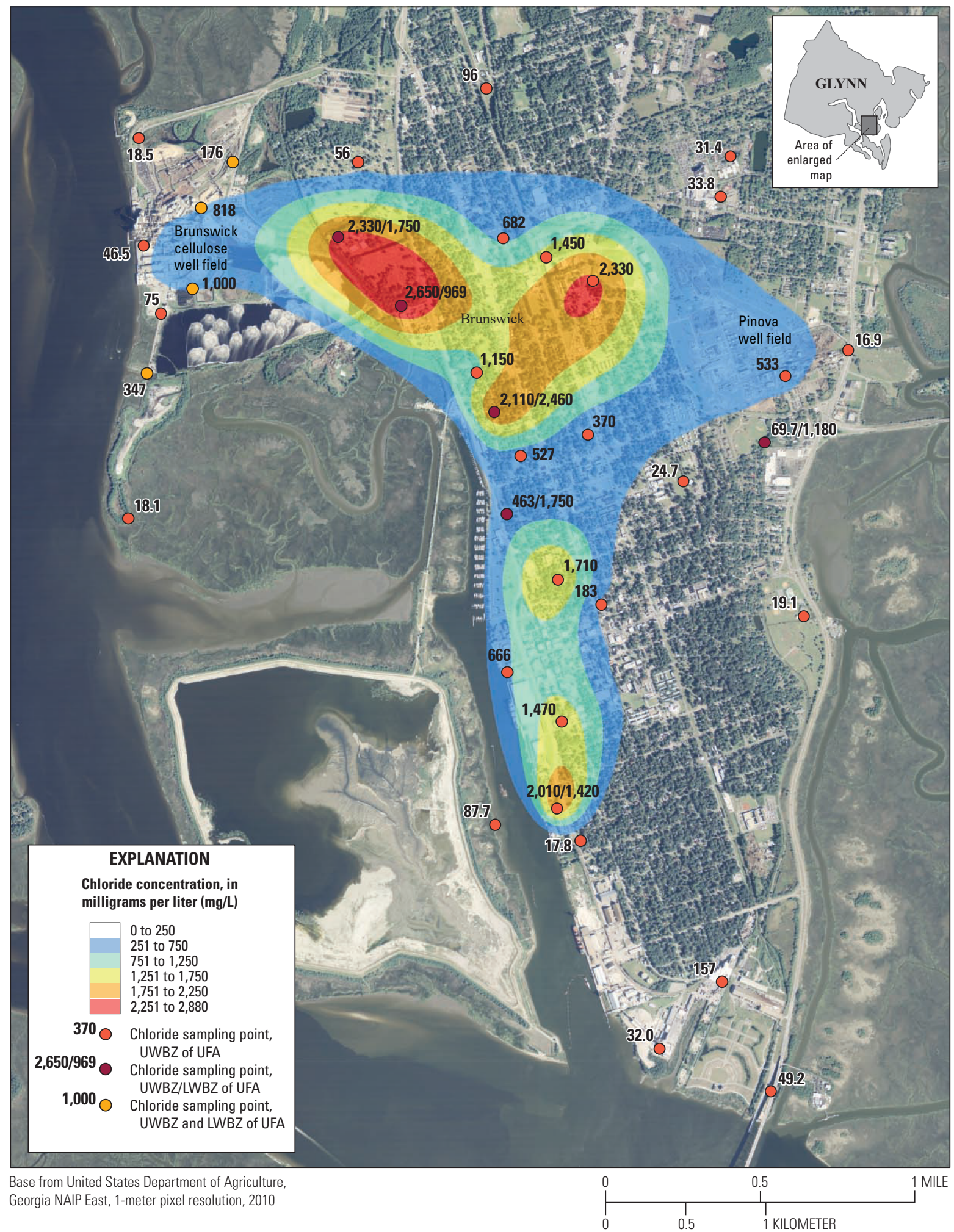

Figure 4. Map showing chloride concentration in the Upper Floridan aquifer in the area near downtown Brunswick, October 2015 [UWBZ, upper water-bearing zone; UFA, Upper Floridan aquifer; LWBZ, lower water-bearing zone]. 


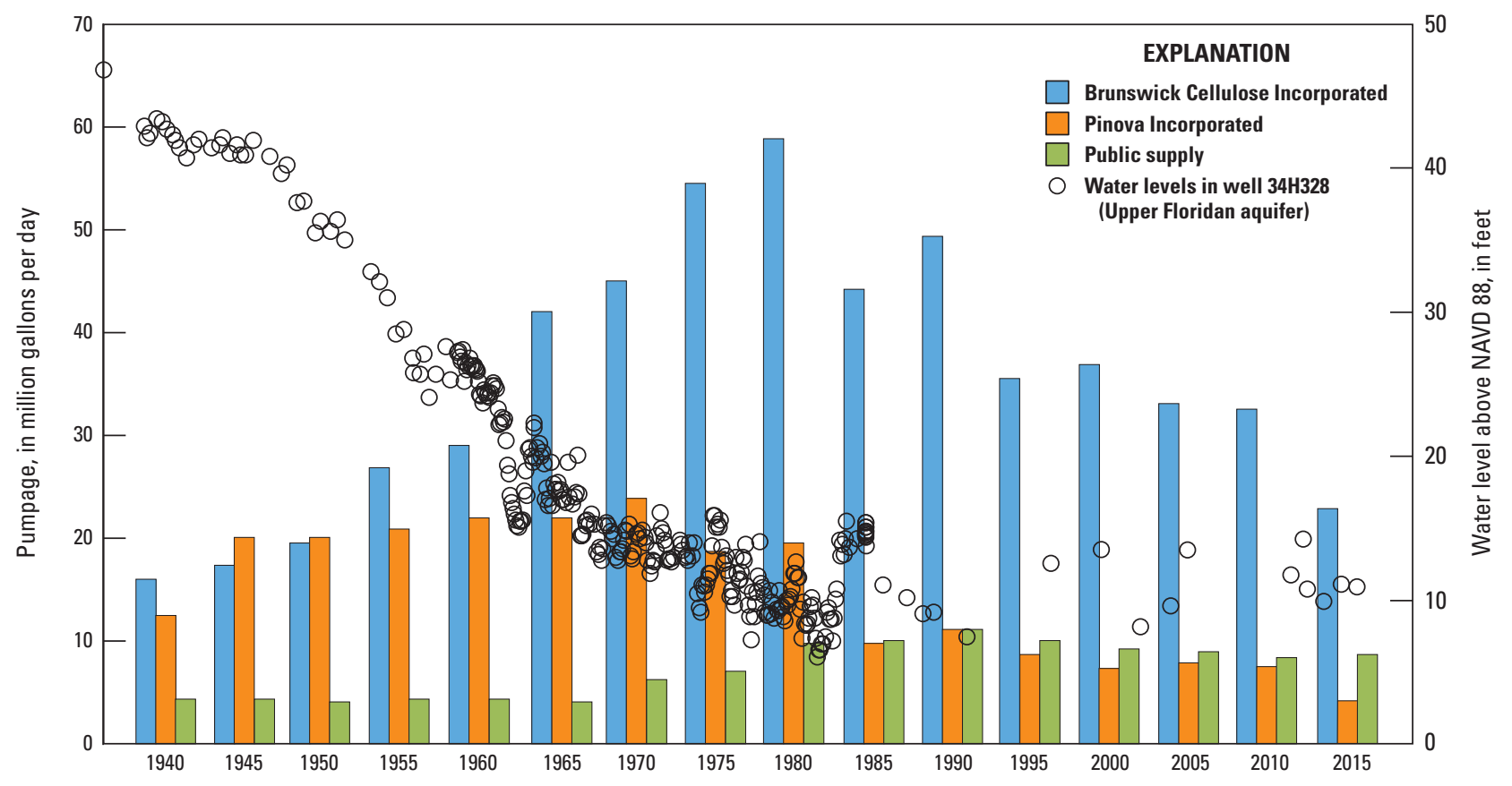

Figure 5. Graph showing major groundwater pumpage from the Upper Floridan aquifer in the Brunswick/Glynn County area, Georgia, 1940-2015, and water levels in well 34H328, 1939-2013.

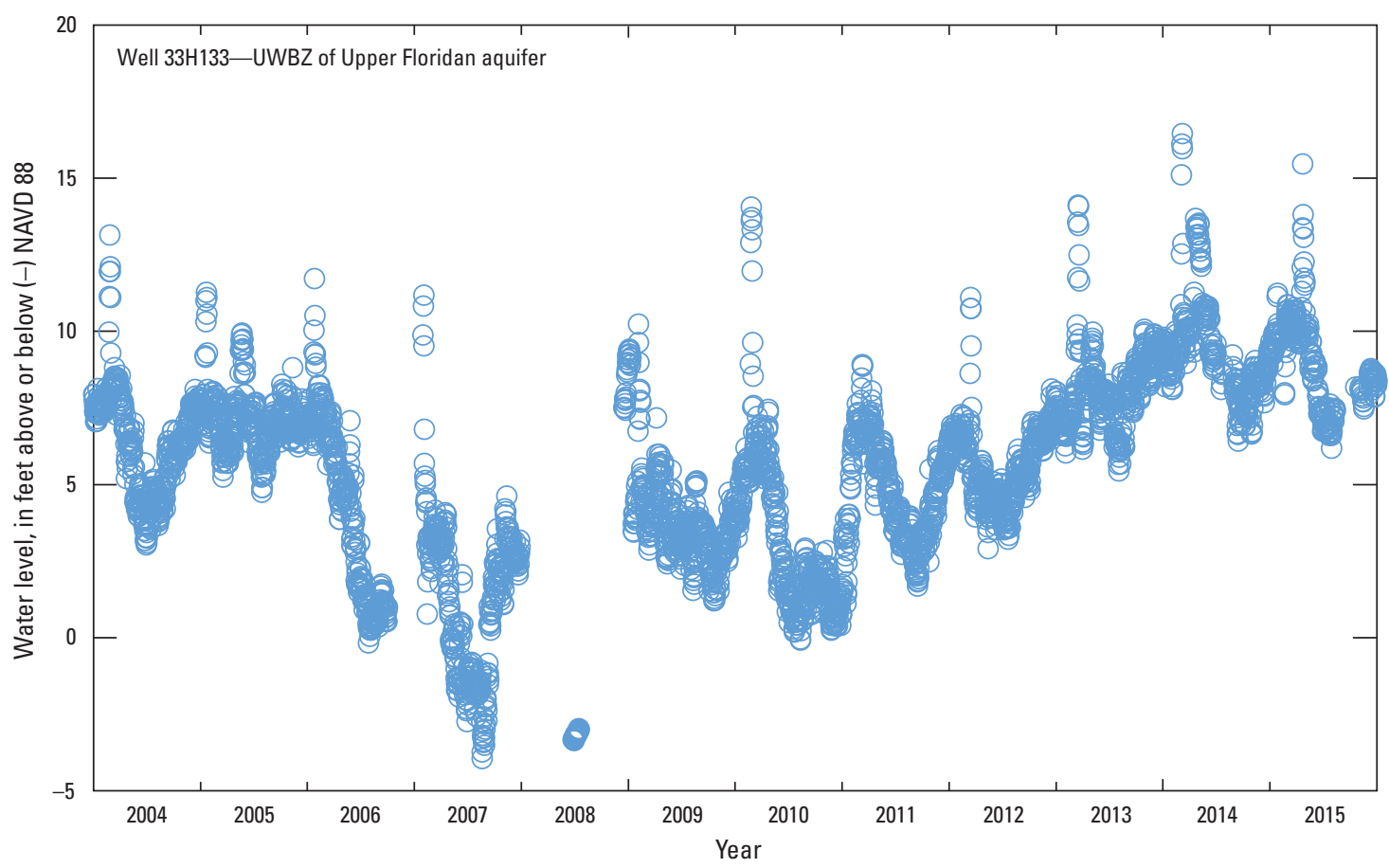

Figure 6. Graph showing water-level of well $33 \mathrm{H} 133$ open to the upper water-bearing zone of the Upper Floridan aquifer in the Brunswick, Georgia, area, 2004-15. 
Table 1. Annual precipitation during 2004-2015 for University of Georgia weather network stations located in southeastern Georgia.

[-, not available; see figure 1 for station locations $]$

\begin{tabular}{lccccccccccccc}
\hline & \multicolumn{10}{c}{ UGA station name } & \multicolumn{10}{c}{ Annual precipitation, in inches per year } \\
\cline { 2 - 12 } & $\mathbf{2 0 0 4}$ & $\mathbf{2 0 0 5}$ & $\mathbf{2 0 0 6}$ & $\mathbf{2 0 0 7}$ & $\mathbf{2 0 0 8}$ & $\mathbf{2 0 0 9}$ & $\mathbf{2 0 1 0}$ & $\mathbf{2 0 1 1}$ & $\mathbf{2 0 1 2}$ & $\mathbf{2 0 1 3}$ & $\mathbf{2 0 1 4}$ & $\mathbf{2 0 1 5}$ & $\begin{array}{c}\text { Annual } \\
\text { average }\end{array}$ \\
\hline Brunswick, Glynn County & 51.80 & 76.12 & 36.56 & 34.51 & 40.04 & 56.12 & 37.43 & 33.20 & 47.62 & 45.13 & 56.45 & 47.69 & $\mathbf{4 6 . 8 9}$ \\
Woodbine, Camden County & - & - & 33.45 & 45.13 & 53.13 & 52.26 & 40.59 & 37.84 & 57.67 & 46.22 & 55.48 & 56.77 & $\mathbf{4 7 . 8 5}$ \\
Nahunta, Brantley County & 64.49 & 52.48 & 30.32 & 40.49 & 37.21 & 54.66 & 36.90 & 49.43 & 42.33 & 44.52 & 48.75 & 46.45 & $\mathbf{4 5 . 6 7}$ \\
Homerville, Clinch County & 56.81 & 51.18 & 32.21 & 35.92 & 49.95 & 55.38 & 39.18 & 39.55 & 49.08 & 60.73 & 49.08 & 44.53 & $\mathbf{4 6 . 9 7}$ \\
Alma, Bacon County & 48.25 & 45.52 & 38.53 & 40.25 & 48.76 & 56.70 & 38.89 & 32.60 & 39.49 & 55.21 & 49.78 & 49.48 & $\mathbf{4 5 . 2 9}$ \\
Douglas, Coffee County & - & - & 28.42 & 35.52 & 42.11 & 56.12 & 39.55 & 30.55 & 44.02 & 46.87 & 41.73 & 45.67 & $\mathbf{4 1 . 0 6}$ \\
Alapaha, Berrien County & 56.06 & 40.04 & 39.97 & 37.01 & 48.11 & 53.51 & 40.12 & 36.64 & 40.20 & 49.63 & 46.48 & 38.98 & $\mathbf{4 3 . 9 0}$ \\
Valdosta, Lowndes County & 48.14 & 59.16 & 40.59 & 37.51 & 52.24 & 53.65 & 47.56 & 46.47 & 47.27 & 50.50 & 55.42 & 58.35 & $\mathbf{4 9 . 7 4}$ \\
Moultrie, Colquitt County & - & - & 30.08 & 47.38 & 48.50 & 56.91 & 43.06 & 39.88 & 38.96 & 60.23 & 66.46 & 47.90 & $\mathbf{4 7 . 9 4}$ \\
Tifton-Bowen, Tift County & 51.61 & 52.66 & 37.99 & 33.79 & 45.31 & 58.72 & 39.80 & 30.41 & 40.05 & 56.97 & 46.04 & 49.35 & $\mathbf{4 5 . 2 3}$ \\
McRae, Telfair County & 50.22 & 41.36 & 40.90 & 39.29 & 48.72 & 61.89 & 40.48 & 36.51 & 44.33 & 67.71 & 50.02 & 49.32 & $\mathbf{4 7 . 5 6}$ \\
Vidalia, Toombs County & 50.98 & 33.11 & 30.87 & 45.42 & 47.36 & 71.60 & 45.84 & 34.26 & 44.85 & 56.20 & 50.72 & 44.31 & $\mathbf{4 6 . 2 9}$ \\
Average & $\mathbf{5 3 . 1 5}$ & $\mathbf{5 0 . 1 8}$ & $\mathbf{3 4 . 9 9}$ & $\mathbf{3 9 . 3 5}$ & $\mathbf{4 6 . 7 9}$ & $\mathbf{5 7 . 2 9}$ & $\mathbf{4 0 . 7 8}$ & $\mathbf{3 7 . 2 8}$ & $\mathbf{4 4 . 6 6}$ & $\mathbf{5 3 . 3 3}$ & $\mathbf{5 1 . 3 7}$ & $\mathbf{4 8 . 2 3}$ & $\mathbf{4 6 . 2 0}$ \\
\hline
\end{tabular}

Table 2. Water-level measurements taken during June 2004 and October 2015 and observed water-level change from 2004 to 2015 in the Brunswick/Glynn County area, Georgia.

[NAVD 88, North American Vertical Datum of 1988; see fig. 1-1 for well locations]

\begin{tabular}{|c|c|c|c|}
\hline \multirow{2}{*}{$\begin{array}{l}\text { Well } \\
\text { identifier }\end{array}$} & \multicolumn{2}{|c|}{$\begin{array}{c}\text { Water level, in feet } \\
\text { above or below NAVD } 88\end{array}$} & \multirow{2}{*}{$\begin{array}{l}\text { Water-level change, } \\
\text { from } 2004 \text { to 2015, } \\
\text { in feet }\end{array}$} \\
\hline & 2004 & 2015 & \\
\hline \multicolumn{4}{|c|}{ Upper Brunswick aquifer (UBA) } \\
\hline 34J081 & -2.50 & 2.02 & 4.52 \\
\hline 34J077 & -13.54 & -5.31 & 8.23 \\
\hline \multirow[t]{2}{*}{$34 \mathrm{H} 437$} & 8.92 & 7.08 & -1.84 \\
\hline & & Mean & 2.35 \\
\hline \multicolumn{4}{|c|}{ Lower Brunswick aquifer (LBA) } \\
\hline 34J080 & 8.52 & 10.68 & 2.16 \\
\hline $33 \mathrm{H} 120$ & 3.08 & 7.98 & 4.90 \\
\hline $33 \mathrm{H} 130$ & 2.18 & 6.83 & 4.65 \\
\hline $33 \mathrm{H} 133$ & 3.77 & 8.20 & 4.43 \\
\hline $33 \mathrm{H} 207$ & 8.09 & 13.31 & 5.22 \\
\hline 34G009 & 38.73 & 39.77 & 1.04 \\
\hline $34 \mathrm{G} 016$ & 28.28 & 28.78 & 0.50 \\
\hline $34 \mathrm{G} 020$ & 30.10 & 31.15 & 1.05 \\
\hline $34 \mathrm{H} 112$ & 12.85 & 15.85 & 3.00 \\
\hline $34 \mathrm{H} 125$ & 12.38 & 11.76 & -0.62 \\
\hline
\end{tabular}


Table 2. Water-level measurements taken during June 2004 and October 2015 and observed water-level change from 2004 to 2015 in the Brunswick/Glynn County area.-Continued

[NAVD 88, North American Vertical Datum of 1988; see fig. 1-1 for well locations]

\begin{tabular}{|c|c|c|c|}
\hline \multirow{2}{*}{$\begin{array}{c}\text { Well } \\
\text { identifier }\end{array}$} & \multicolumn{2}{|c|}{$\begin{array}{c}\text { Water level, in feet } \\
\text { above or below NAVD } 88\end{array}$} & \multirow{2}{*}{$\begin{array}{l}\text { Water-level change, } \\
\text { from } 2004 \text { to } 2015, \\
\text { in feet }\end{array}$} \\
\hline & 2004 & 2015 & \\
\hline $34 \mathrm{H} 355$ & 8.46 & 12.51 & 4.05 \\
\hline $34 \mathrm{H} 371$ & 15.54 & 18.96 & 3.42 \\
\hline \multirow[t]{2}{*}{$34 \mathrm{H} 469$} & 6.61 & 11.49 & 4.88 \\
\hline & & Mean & 3.11 \\
\hline \multicolumn{4}{|c|}{ Lower water-bearing zone of Upper Floridan aquifer (LWBZ of UFA) } \\
\hline $33 \mathrm{H} 127$ & 7.85 & 12.76 & 4.91 \\
\hline \multicolumn{4}{|c|}{ Lower Floridan aquifer (LFA) } \\
\hline $33 \mathrm{H} 206$ & 14.41 & 16.41 & 2.00 \\
\hline $34 \mathrm{H} 391$ & 11.87 & 16.46 & 4.59 \\
\hline \multirow[t]{2}{*}{$34 \mathrm{H} 436$} & 15.72 & 19.33 & 3.61 \\
\hline & & Mean & 3.40 \\
\hline
\end{tabular}

\section{Simulation of Groundwater Flow}

A single-density, digital groundwater-flow model (herein called the original model) developed to simulate regional confined groundwater flow in the coastal area of Georgia, Florida, South Carolina, and adjacent offshore areas (Payne and others, 2005) was modified to provide more detailed simulations in the Glynn County area. The original model was developed using the USGS finite-difference code MODFLOW-2000 (Harbaugh and others, 2000) and was used to simulate steady-state flow for predevelopment, 1980, and 2000 conditions. The original model was revised (Cherry, 2015) to simulate the long-term, steady-state effect of changes in mean-annual pumping during 2000 and 2004 on groundwater levels and to evaluate changes in hydraulichead gradients near pumping centers in the Brunswick area (fig. $7 A-B$ ). The revisions to the original model made for this study included (1) increased spatial resolution near the downtown Brunswick area, (2) the addition of hydraulic-property geographic zones within the UFA near the Brunswick/Glynn County area, (3) subdivision of the Brunswick aquifer system, and (4) subdivision of the Floridan aquifer system into separate model layers to represent the local hydrogeology (fig. 8). The groundwater-flow model revised by Cherry (2015) was updated to include mean monthly pumping rates during October 2015 for selected production wells near the downtown Brunswick area, and was used to delineate 2015 Base Case conditions and as the basis to evaluate simulated changes in five groundwater-management scenarios presented in the current report. The reader is referred to Cherry (2015) for a complete discussion of revisions to the original model of Payne and others (2005) and calibration to observed water levels during 2000 and 2004.

The original model by Payne and others (2005) encompasses 42,155 $\mathrm{mi}^{2}$ and consists of 119 rows and 108 columns, with cell sizes ranging from 4,000 x 5,000 ft $\left(0.7 \mathrm{mi}^{2}\right)$ to $16,500 \times 16,500 \mathrm{ft}\left(9.8 \mathrm{mi}^{2}\right)$. The focus on the Brunswick/Glynn County area for the current study and that of Cherry (2015) required a greater grid density to simulate steeper hydraulic-head gradients (cones of depression) in the UFA near pumping centers. The groundwater-flow model revised by Cherry (2015) used graphical grid-generation tools from the graphical user interface ARGUS, which enabled visual adjustment of grid position, orientation, and density. The revised model with new grid configuration has the same orientation, but the number of rows and columns has been increased to 424 and 452, respectively (fig. $7 \mathrm{~A}$ ). 


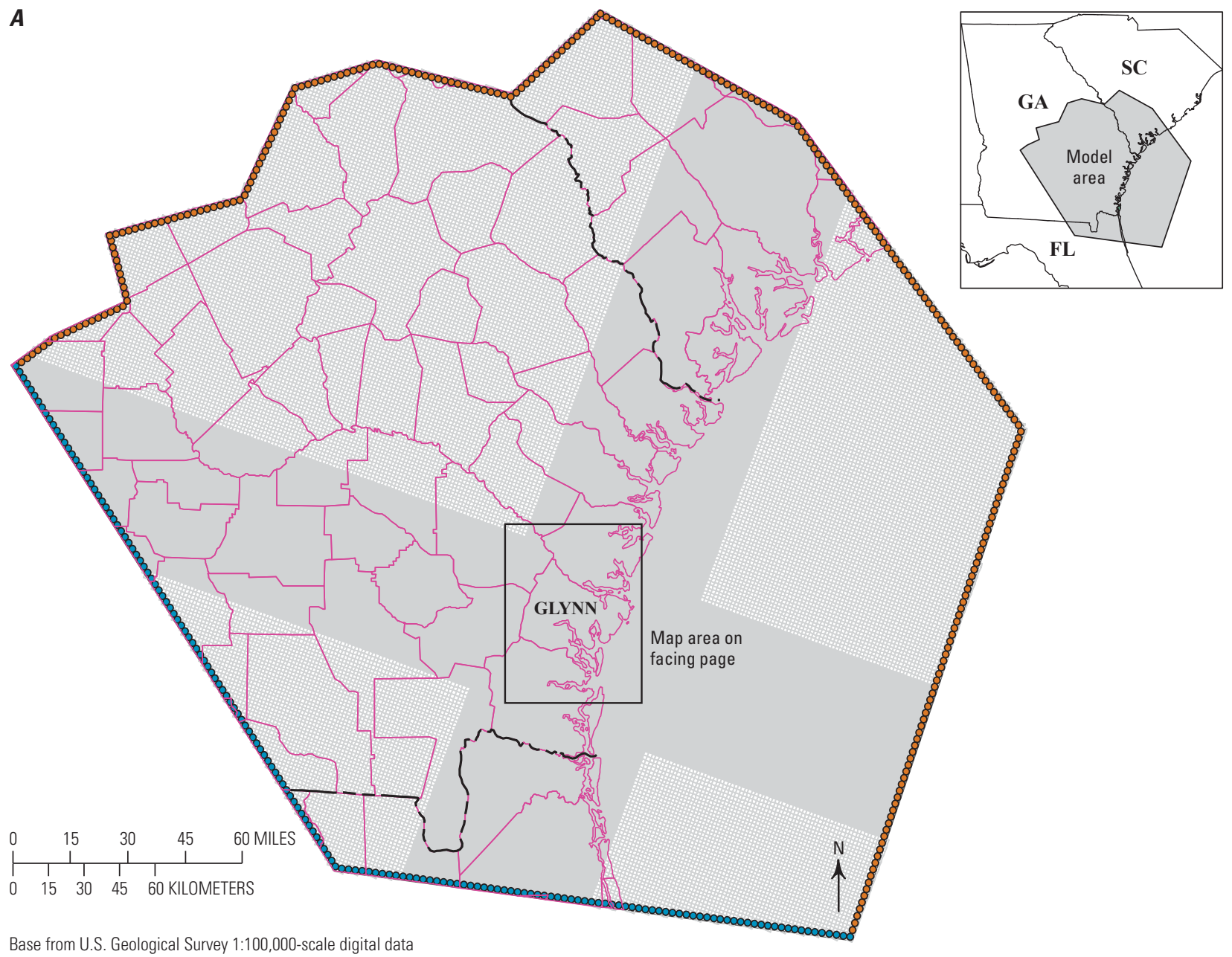

\section{EXPLANATION}

Area of dense model grid - Grid spacing progressively increases by a factor of 1.5 from a minimum of 500 feet to a maximum of 5,000 feet

Model grid

Line of equal 250 milligram per liter chloride concentration 2004-Modified from Leeth and others, 2007

Model-boundary nodes

- $\quad$ Specified head

- No-flow

Figure 7. Maps showing $(A)$ revised model grid of Cherry (2015) and $(B)$ major production wells, observation wells used during October 2015, and outline of the 2004 chloride plume for the Upper Floridan aquifer in the Brunswick, Georgia, area. 

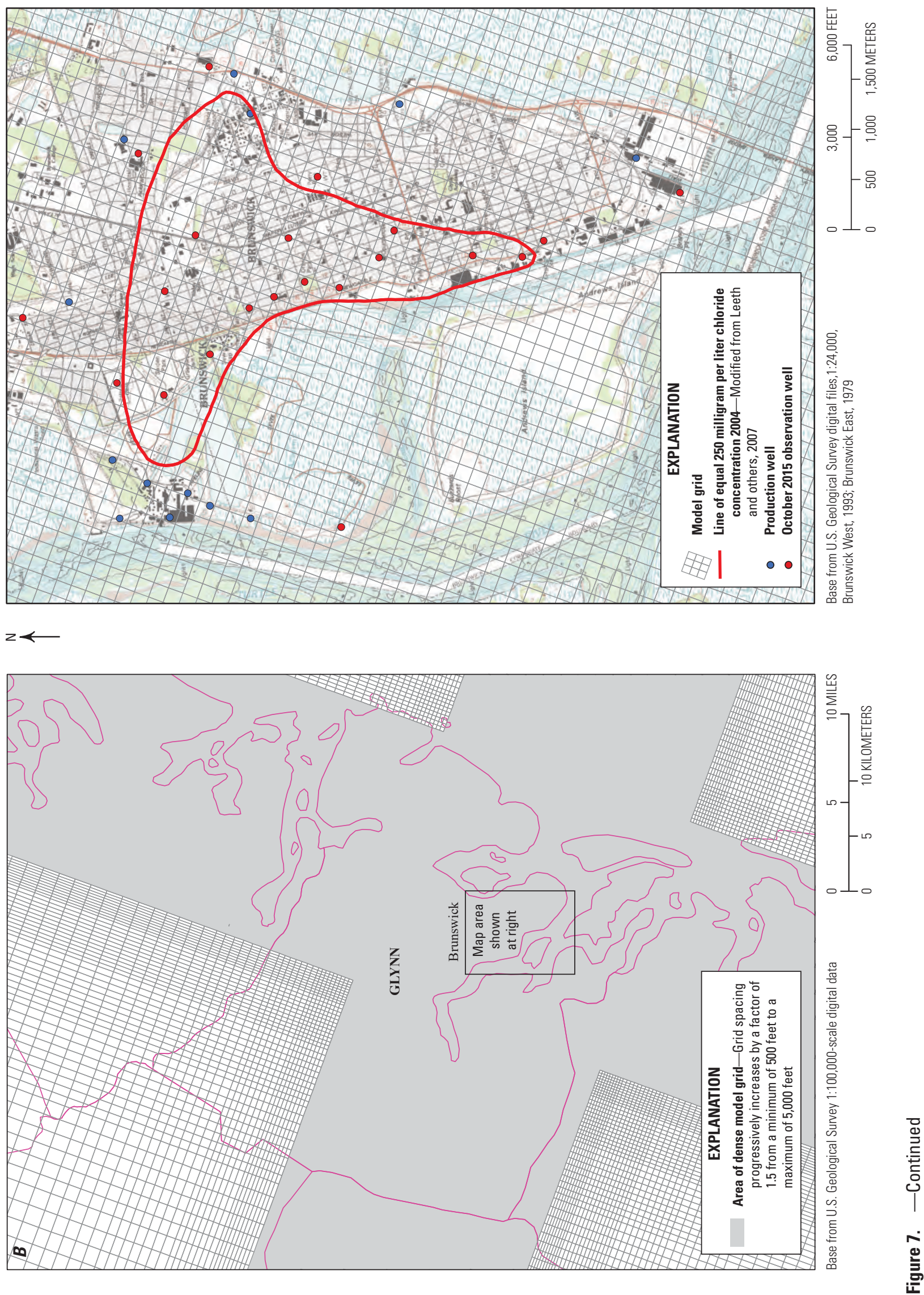


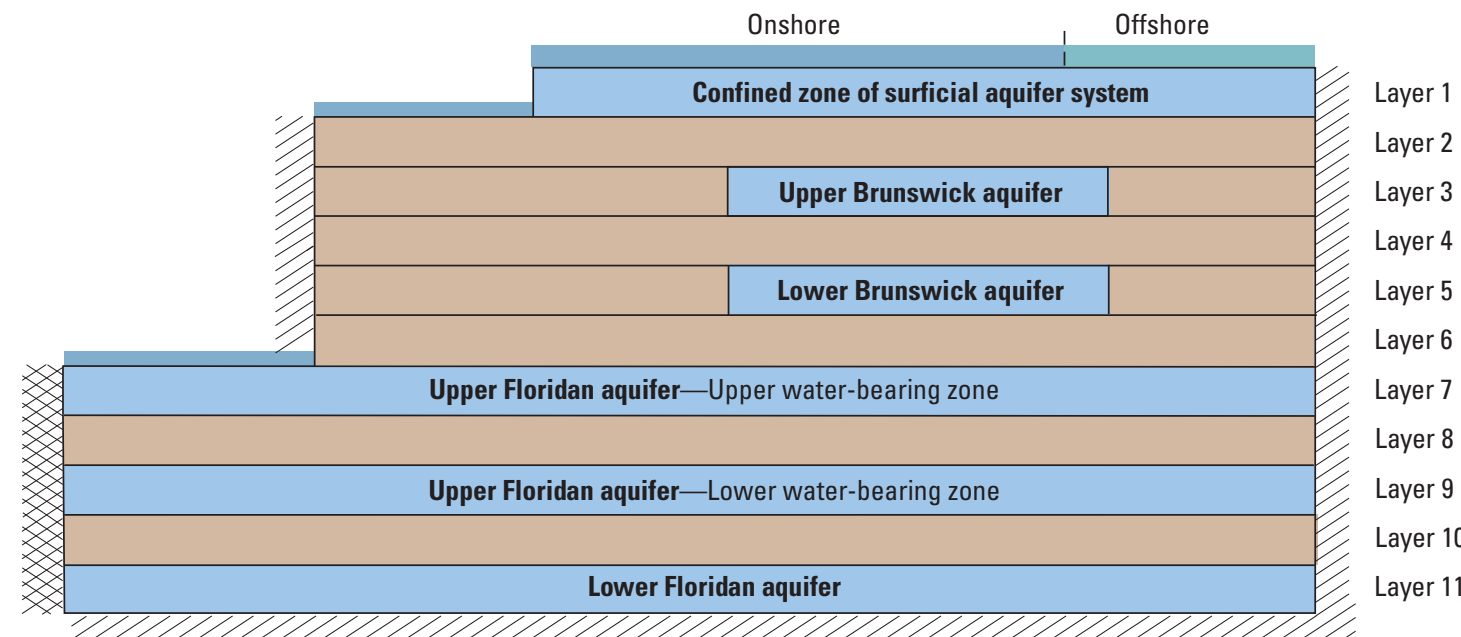

\section{EXPLANATION}

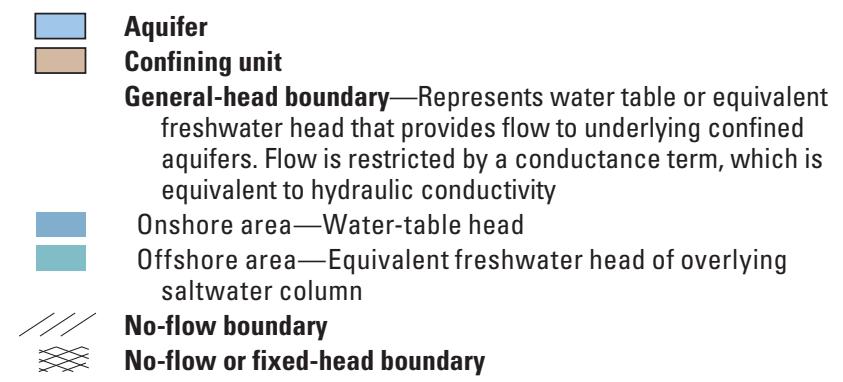

Figure 8. Schematic diagram showing revised model (Cherry, 2015) layers and boundary conditions.

The variable cell sizes range from $500 \times 500 \mathrm{ft}\left(0.009 \mathrm{mi}^{2}\right)$ in the city of Brunswick to $5,000 \times 5,000 \mathrm{ft}\left(0.90 \mathrm{mi}^{2}\right)$ near the edges of the model (Cherry, 2015). The irregular grid configuration results in elongated cells, having aspect ratios as large as 10:1 between row and column spacings along the outer margins of the model. This large aspect ratio is approaching the recommended limit above which numerical errors could occur (de Marsily, 1986, p. 351). The pumping rates in the groundwater-flow model revised by Cherry (2015) have been updated to include adjusted rates during October 2015 for selected production wells located in the Brunswick/St. Simons Island area, which includes wells within or adjacent to the chloride plume in downtown Brunswick. The recalibrated model represents a 2015 Base Case simulation and was used as the basis to evaluate five groundwater-management scenarios.

In the Brunswick/Glynn County area, the original model by Payne and others (2005) contained designated homogeneous and isotropic hydraulic-property geographic zones within model layers (herein referred to as "geographic zones") representing all aquifers and confining units except the UFA, which consisted of three zones within Glynn County (F5, F7, and F8). For the groundwater-flow model revised by Cherry (2015), additional zones were designated on the basis of available aquifer-test and geologic data (Clarke and others, 2004; fig. 9; table 3). Additional zones were created (F13, F14, and F15) within the UFA (layers 7-9) near the
Brunswick area to further adjust hydraulic properties within geographic zone F7 of the original model. In the revised model, three model layers $(3,4$, and 5$)$ vertically subdivide the Brunswick aquifer system, and geographic zone B1 represents a less permeable part of the aquifer (layer 4) juxtaposed between two more permeable parts (layers 3 and 5 ), with each layer assigned a uniform value for horizontal and vertical hydraulic conductivity ( $\mathrm{Kh}$ and $\mathrm{Kv}$, respectively; table 3). To enable more detailed simulation of groundwater flow in the Brunswick/Glynn County area than was available using the original model, the UFA in the revised model has been vertically subdivided into the UWBZ (layer 7) and LWBZ (layer 9), separated by a semi-confining unit (layer 8; fig. 8). In the UFA, each of these new layers contained the same 12 geographic zones used in the original model of Payne and others (2005), plus an additional 3 geographic zones in the Brunswick area to represent lateral variations in horizontal hydraulic conductivity (fig. 9; table 3). In addition, two geographic zones (F16 and F17; fig. 9) were based on the revised model's ability to simulate interaquifer leakage from the UFA to the LFA through the confining unit caused by pumping in newly constructed LFA wells near Hunter Army Airfield and Fort Stewart, Georgia (Clarke and others, 2010, 2011). Overall, the values assigned to the 17 geographic zones for model layers 7 and 9 assigned by Cherry (2015) range from 20 to 3,415 feet per day $(\mathrm{ft} / \mathrm{d})$ with an average of $540 \mathrm{ft} / \mathrm{d}$. 

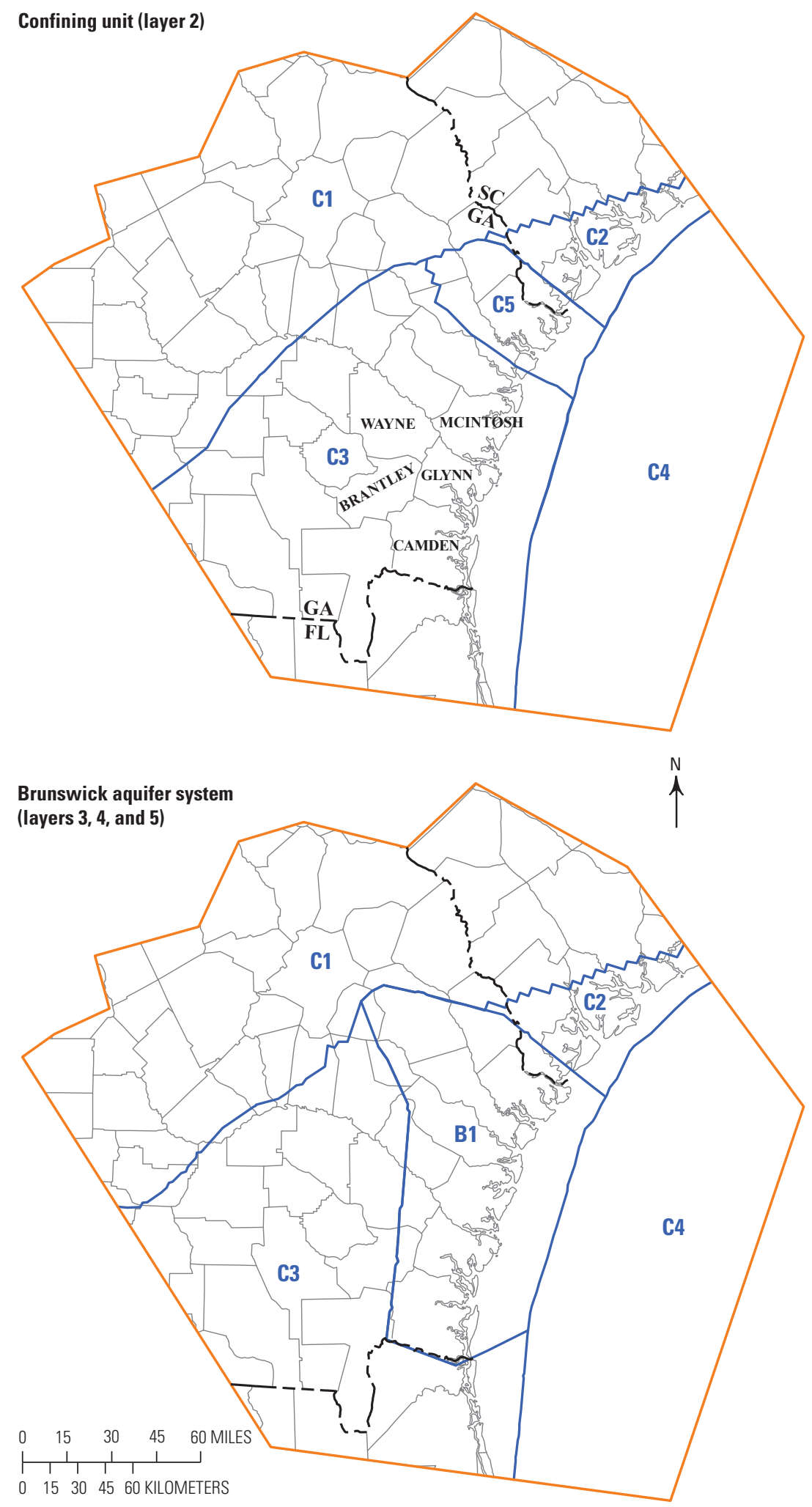

Base from U.S. Geological Survey 1:100,000-scale digital data

Figure 9. Maps showing hydraulic-property geographic zones for the groundwater-flow model revised by Cherry (2015) near Brunswick/Glynn County, Georgia.

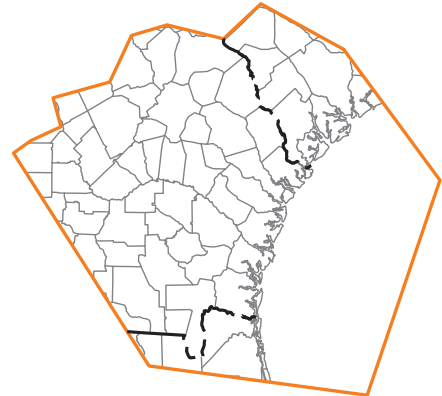

Surficial aquifer system (layer 1)

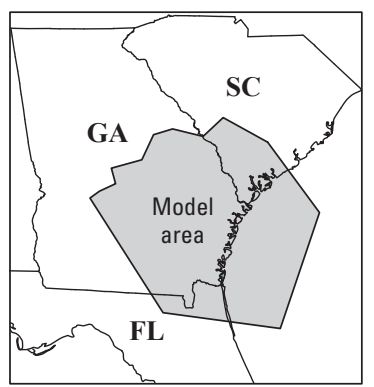

EXPLANATION

C1 Hydraulic-property geographic zone 

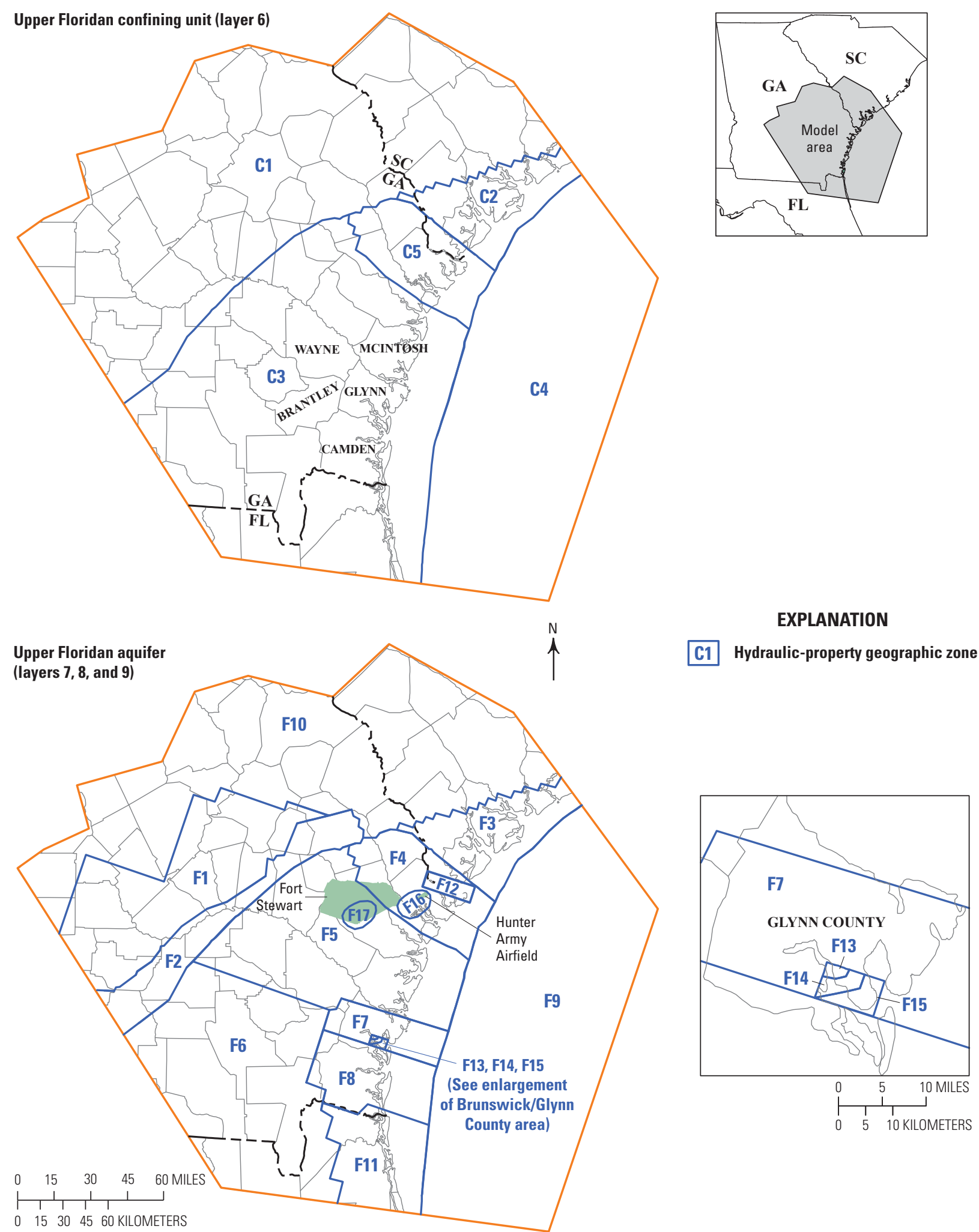

C1 Hydraulic-property geographic zone

Base from U.S. Geological Survey 1:100,000-scale digital data

Figure 9. - Continued 

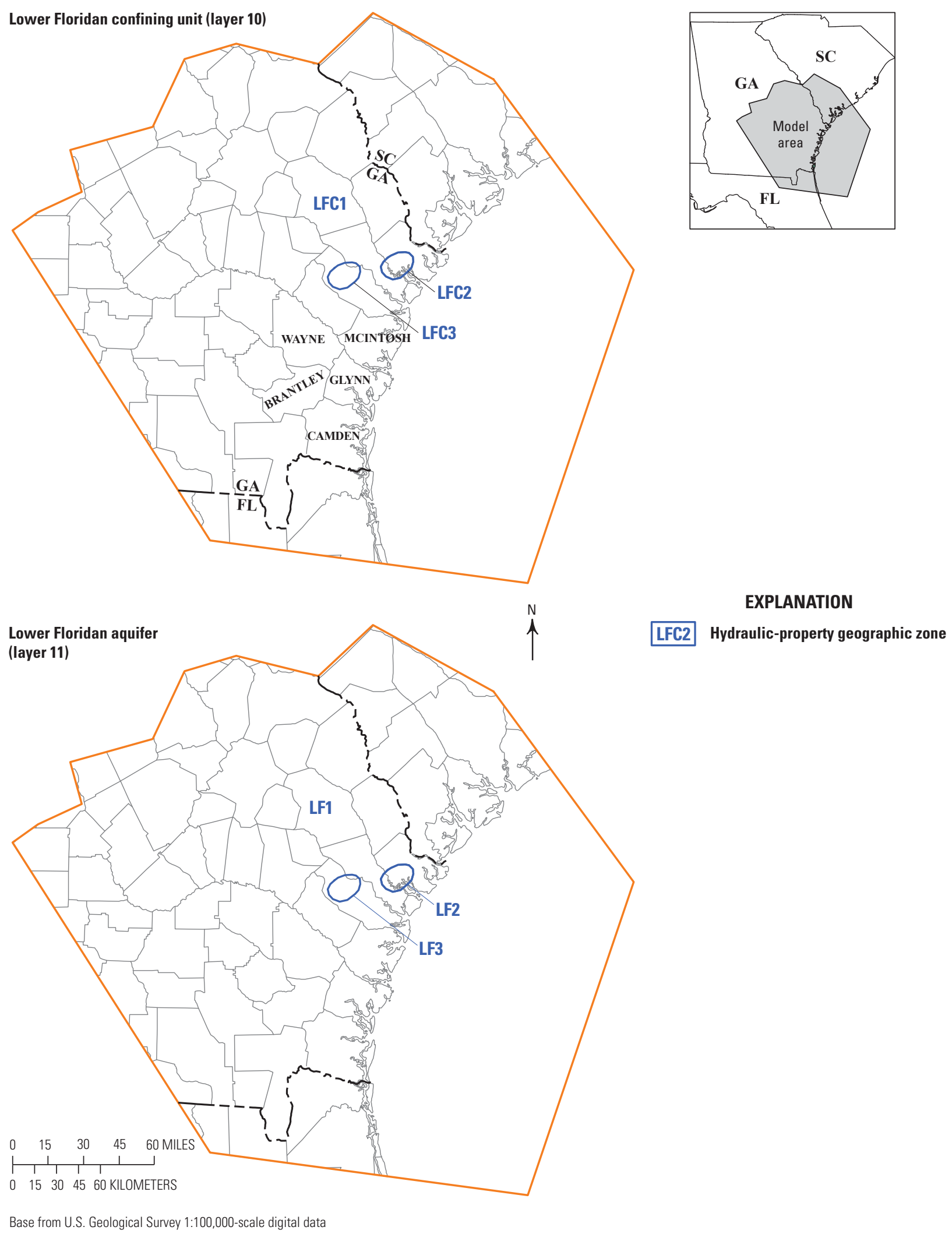

Figure 9. - Continued 
Table 3. Horizontal and vertical hydraulic conductivity values assigned to hydraulic-property geographic zones for the groundwater-flow model revised by Cherry (2015) in the Glynn County area and adjacent counties in Georgia.

[-, not applicable; UWBZ, upper water-bearing zone; LWBZ, lower waterbearing zone; Kh, horizontal hydraulic conductivity; Kv, vertical hydraulic conductivity]

\begin{tabular}{|c|c|c|c|}
\hline \multirow[b]{2}{*}{ Unit } & \multirow[b]{2}{*}{ Layer } & \multicolumn{2}{|c|}{ Revised model } \\
\hline & & $\begin{array}{l}\text { Hydraulic- } \\
\text { property } \\
\text { geographic } \\
\text { zone (fig. 9) }\end{array}$ & $\begin{array}{c}\text { Hydraulic } \\
\text { conductivity, } \\
\text { Kh and Kv, } \\
\text { in feet per day }\end{array}$ \\
\hline Surficial aquifer & 1 & - & 105 \\
\hline Confining unit & 2 & $\mathrm{C} 3$ & 0.00001 \\
\hline \multirow[t]{2}{*}{ Upper Brunswick aquifer } & 3 & B1 & 10 \\
\hline & & $\mathrm{C} 3$ & 0.00001 \\
\hline \multirow[t]{2}{*}{ Confining unit } & 4 & B1 & 0.02 \\
\hline & & $\mathrm{C} 3$ & 0.00001 \\
\hline \multirow[t]{2}{*}{ Lower Brunswick aquifer } & 5 & B1 & 20 \\
\hline & & $\mathrm{C} 3$ & 0.00001 \\
\hline Confining unit & 6 & $\mathrm{C} 3$ & 0.00001 \\
\hline \multirow{7}{*}{$\begin{array}{l}\text { UWBZ of Upper Floridan } \\
\text { aquifer }\end{array}$} & 7 & F5 & 225 \\
\hline & & F6 & 3,415 \\
\hline & & F7 & 750 \\
\hline & & F8 & 3,000 \\
\hline & & F13 & 300 \\
\hline & & F14 & 240 \\
\hline & & F15 & 200 \\
\hline \multirow[t]{7}{*}{ Confining unit } & 8 & F5 & 225 \\
\hline & & F6 & 3,415 \\
\hline & & F7 & 0.2 \\
\hline & & F8 & 0.2 \\
\hline & & F13 & 0.2 \\
\hline & & F14 & 0.2 \\
\hline & & F15 & 0.2 \\
\hline \multirow{7}{*}{$\begin{array}{l}\text { LWBZ of Upper Floridan } \\
\text { aquifer }\end{array}$} & 9 & F5 & 225 \\
\hline & & F6 & 3,415 \\
\hline & & F7 & 750 \\
\hline & & F8 & 3,000 \\
\hline & & F13 & 270 \\
\hline & & F14 & 200 \\
\hline & & F15 & 125 \\
\hline Confining unit & 10 & LFC1 & 0.02000 \\
\hline Lower Floridan aquifer & 11 & LF1 & 10 \\
\hline
\end{tabular}

Model performance for 2004 and 2015 Base Case conditions was evaluated on the basis of differences (residuals are defined here as the simulated head minus the observed "water level") as well as the corresponding mean, median, and root-mean-square error (RMSE) statistics. The mean residual is a good indicator of bias in the differences between simulated and observed heads. The median residual is more robust than the mean in the presence of outlier values. RMSE, derived from residuals as the square root of the average deviation of the residuals from zero, yields a measure of overall fit of simulated heads to observed groundwater levels. The calibration criteria used near the Brunswick/Glynn County area in the revised model were more stringent than those used in the original model because of the relatively low topographic relief in the area and the availability of 5-ft contour intervals on local topographic maps. For altitudes determined from topographic maps near the downtown Brunswick area, one-half the contour interval $(2.5 \mathrm{ft})$ is considered to be the accuracy of well data, including groundwater-level measurements, formation altitudes, and so forth. For the revised model, the calibration target (established error criteria) for the 2000 and 2004 simulations was $10 \mathrm{ft}$ for areas outside Glynn County and $5 \mathrm{ft}$ near downtown Brunswick. The primary objective of the 2004 and 2015 Base Case calibrations was to achieve the best possible match of simulated heads to observed groundwater levels in the UWBZ of the UFA near the Brunswick/Glynn County area. The 2015 Base Case calibration only evaluated residuals in the Brunswick/Glynn County area because 2004 pumping rates were not updated for the remaining areas of the regional model.

For the 2004 calibration, residuals (simulated head minus observed head) from 32 observation wells in model layer 7, UWBZ of the UFA, ranged from -18.9 to $3.98 \mathrm{ft}$, with a mean of $-2.56 \mathrm{ft}$, median of $-1.50 \mathrm{ft}$, and an RMSE of $5.34 \mathrm{ft}$ (table 4). For model layer 9, LWBZ of the UFA, residuals from five wells located near downtown Brunswick ranged from -6.15 to $20.8 \mathrm{ft}$, with a mean of $1.20 \mathrm{ft}$ and a median of $-3.30 \mathrm{ft}$. In the Brunswick/Glynn County area, the distribution of water-level residuals in the UWBZ of the UFA (layer 7) indicates an acceptable match, with a mean residual of $-2.56 \mathrm{ft}$ and 75 percent of the values within the established error criterion of $5 \mathrm{ft}$. However, the map showing the distribution of water-level residuals indicates an acceptable match in the downtown Brunswick area with four large negative values (outliers) for wells located on Jekyll Island. 
Table 4. Calibration statistics for simulated heads for 2004 conditions in Glynn County, Georgia (Cherry, 2015).

[Residual equals simulated minus observed head; - , not calculated because less than 10 values; UWBZ, upper water-bearing zone; LWBZ, lower water-bearing zone]

\begin{tabular}{|c|c|c|c|c|c|}
\hline Calibration statistic & $\begin{array}{c}\text { Upper } \\
\text { Brunswick } \\
\text { aquifer } \\
\text { (layer 3) }\end{array}$ & $\begin{array}{l}\text { Lower } \\
\text { Brunswick } \\
\text { aquifer } \\
\text { (layer 5) }\end{array}$ & $\begin{array}{c}\text { UWBZ of } \\
\text { Upper Floridan } \\
\text { aquifer } \\
\text { (layer 7) }\end{array}$ & $\begin{array}{l}\text { LWBZ of } \\
\text { Upper Floridan } \\
\text { aquifer } \\
\text { (layer 9) }\end{array}$ & $\begin{array}{c}\text { Lower } \\
\text { Floridan } \\
\text { aquifer } \\
\text { (layer 11) }\end{array}$ \\
\hline Number of observations & 6 & 2 & 32 & 5 & 7 \\
\hline Range of observations (feet) & 33.8 & 13.6 & 42.9 & 34.2 & 12.1 \\
\hline Maximum residual (feet) & 9.30 & -6.26 & 3.98 & 20.8 & 1.98 \\
\hline Mean residual (feet) & -0.77 & -9.38 & -2.56 & 1.20 & -4.50 \\
\hline Median residual (feet) & -0.66 & - & -1.50 & -3.30 & -3.73 \\
\hline Root-mean-square error residual (feet) & - & - & 5.34 & - & - \\
\hline Residuals within 10 -foot error criteria (percent) & 83 & 50 & 91 & 80 & 86 \\
\hline
\end{tabular}

Simulated potentiometric surfaces of the UFA (layers 7 and 9) for 2004 (Cherry, 2015) indicate groundwater flow is from upland areas in the west, eastward toward the Savannah area (fig. 10). Groundwater also flows from the Brunswick/Glynn County area roughly parallel to the coast northeastward toward the Savannah area. Simulated potentiometric surface maps of the UFA (represented in the model by layers 7 and 9) for 2004 show steep potentiometric gradients in the upland areas north and west of the Gulf Trough, with groundwater-flow directions toward coastal Georgia (figs. 1 and 10). Groundwater-flow directions are influenced by a cone of depression centered in the Savannah area that alters the coastward flow pattern. The broad area of influence for this cone of depression is evident by the 0 - $\mathrm{ft}$ contour, which extends to an area of pumping to the southwest near Jesup, Ga., and north into Jasper and Beaufort Counties, S.C. (fig. 1). Simulated potentiometric contours in the Savannah area show water-level altitudes below $-80 \mathrm{ft}$ in layers 7 and 9. In the Brunswick/Glynn County area, potentiometric contours indicate groundwater flow from the southwest to northeast, with a cone of depression near downtown Brunswick locally altering the coastward flow pattern (model layer 7 shown in fig. 11).

\section{Base Case Condition}

For the 2015 Base Case calibration, residuals from 26 observation wells in model layer 7, UWBZ of UFA, ranged from -17.3 to $5.48 \mathrm{ft}$, with a mean of $-0.25 \mathrm{ft}$, median of $1.00 \mathrm{ft}$, and an RMSE of $4.89 \mathrm{ft}$ (table 5). For model layer 9, LWBZ of UFA, residuals from five wells located near downtown Brunswick ranged from -3.20 to $1.50 \mathrm{ft}$, with a mean of $-0.64 \mathrm{ft}$ and a median of $-0.50 \mathrm{ft}$. In the Brunswick/ Glynn County area, the distribution of water-level residuals in the UWBZ of the UFA (layer 7) indicates an acceptable match, with a mean residual of $-0.25 \mathrm{ft}$ and 81 percent of the values within the established error criterion of $5 \mathrm{ft}$. The map showing the distribution of water-level residuals also indicates an improved match in the downtown Brunswick area with four large negative values for wells located on Jekyll Island (fig. 11).

The simulated results from the 2015 Base Case indicate predominant groundwater-flow directions across Glynn County from the southwest and south and moving in a northeast direction into neighboring McIntosh County. The potentiometric surface map for model layer 7, UWBZ of the UFA, indicates simulated heads greater than $25 \mathrm{ft}$ in the southwest corner of Glynn County with the 15 -ft contour in close proximity to the boundary with McIntosh County (fig. 11). Near downtown Brunswick, the cone of depression influences groundwater-flow directions along the Brunswick peninsula with flow components from all directions toward the center of pumping at Brunswick Cellulose. The 15-ft contour encompasses most of downtown Brunswick with groundwaterflow directions toward the 0 -ft contour, which surrounds the Brunswick Cellulose well field. The horizontal hydraulic-head gradient in groundwater flow from the west, southwest, and south toward Brunswick ranges from 7 to $8 \mathrm{ft} / \mathrm{mi}$. The gradient from the east and northeast toward the pumping center is about $3 \mathrm{ft} / \mathrm{mi}$ and is influenced by other active production wells in the area. 
A. Upper water-bearing zone of Upper Floridan aquifer (layer 7)

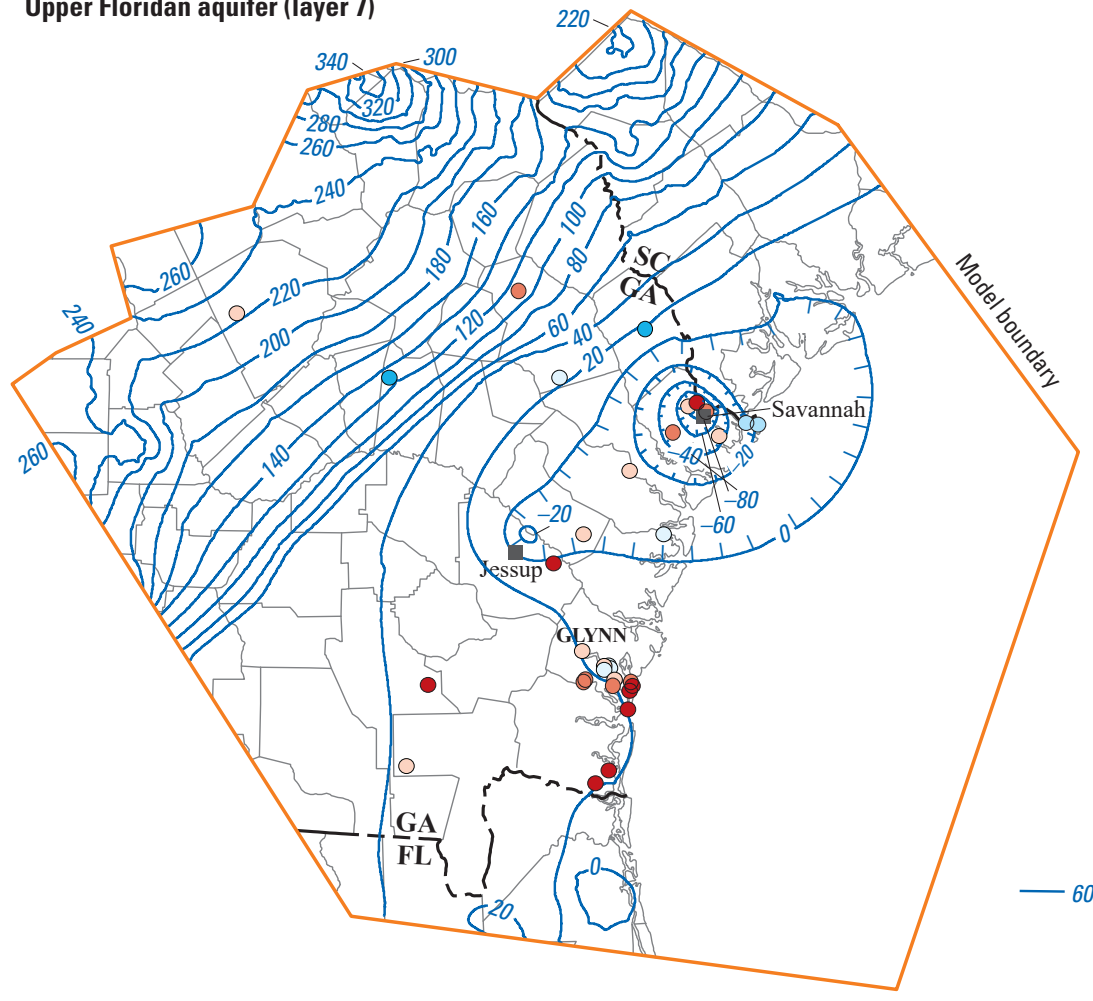

B. Lower water-bearing zone of Upper Floridan aquifer (layer 9)

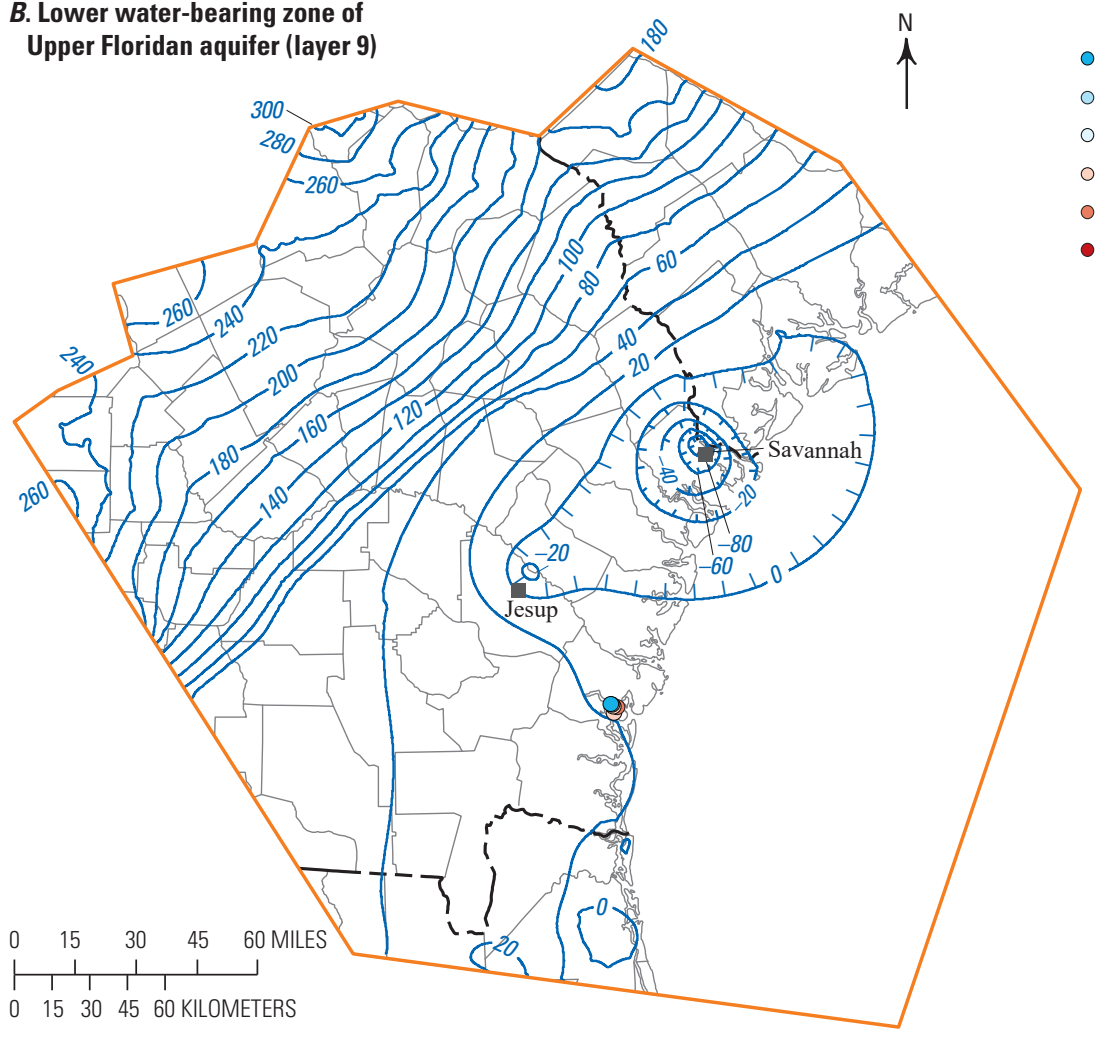

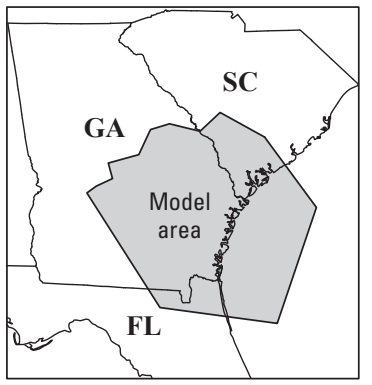

\section{EXPLANATION}

60 - Simulated potentiometric contour-Shows simulated 2004 potentiometric surface, in feet. Hachures indicate depression. Contour interval 20 feet. Datum is NAVD 88

Water-level residual, in feet-Represents simulated minus observed water levels

10.01 to 20

5.01 to 10

0 to 5

-0.01 to -5

-5.01 to -10

-10.01 to -20

Base from U.S. Geological Survey 1:100,000-scale digital data

Figure 10. Maps showing simulated 2004 potentiometric surfaces and water-level residuals by model layer: $(A)$ layer 7, upper waterbearing zone of the Upper Floridan aquifer; and $(B)$ layer 9, lower water-bearing zone of the Upper Floridan aquifer, Brunswick/Glynn County area, Georgia. 
Table 5. Calibration statistics for simulated heads for 2015 Base Case in Glynn County, Georgia.

[Residual equals simulated minus observed head; - , not calculated because less than 10 values; UWBZ, upper water-bearing zone; LWBZ, lower water-bearing zone]

\begin{tabular}{|c|c|c|c|c|c|}
\hline Calibration statistic & $\begin{array}{c}\text { Upper } \\
\text { Brunswick } \\
\text { aquifer } \\
\text { (layer 3) }\end{array}$ & $\begin{array}{l}\text { Lower } \\
\text { Brunswick } \\
\text { aquifer } \\
\text { (layer 5) }\end{array}$ & $\begin{array}{l}\text { UWBZ of } \\
\text { Upper Floridan } \\
\text { aquifer } \\
\text { (layer 7) }\end{array}$ & $\begin{array}{l}\text { LWBZ of } \\
\text { Upper Floridan } \\
\text { aquifer } \\
\text { (layer 9) }\end{array}$ & $\begin{array}{c}\text { Lower } \\
\text { Floridan } \\
\text { aquifer } \\
\text { (layer 11) }\end{array}$ \\
\hline \multicolumn{6}{|c|}{2015 Base Case } \\
\hline Number of observations & 5 & 2 & 26 & 5 & 4 \\
\hline Range of observations (feet) & 17.5 & 12.3 & 32.9 & 9.30 & 13.3 \\
\hline Maximum residual (feet) & 3.80 & 23.0 & 5.48 & 1.50 & 0.80 \\
\hline Mean residual (feet) & 0.92 & -9.76 & -0.25 & -0.64 & -3.73 \\
\hline Median residual (feet) & 1.61 & - & 1.00 & -0.50 & -1.75 \\
\hline Root-mean-square error residual (feet) & - & - & 4.89 & - & - \\
\hline
\end{tabular}

Steady-state simulations of water levels for 2004 and 2015 indicate groundwater-level rises in the UFA within Glynn County, corresponding to a decrease in the rate of pumping during this period. The simulated water-level changes for the 2015 Base Case compared to the 2004 calibrated simulation for each grid cell indicate a range from $-2.0 \mathrm{ft}$ to greater than $+7 \mathrm{ft}$ (fig. 12). In Glynn County, simulated waterlevel increases in the UFA (layers 7 and 9) were caused by decreases in pumping rates represented in the steady-state models from 2004 to 2015 Base Case. Simulated groundwaterlevel increases generally range between 1 and $7 \mathrm{ft}$, with the greatest simulated increase occurring near downtown Brunswick (appendix 1). Decreases in pumping rates in the UFA from 55.2 million gallons per day (Mgal/d) during 2004 to $45.2 \mathrm{Mgal} / \mathrm{d}$ during $2015 \mathrm{Base}$ Case, represented in the models, contributed to the rises in simulated water levels. The simulated water-level change contours near the Brunswick Cellulose well field indicate about $10 \mathrm{ft}$ of change due to variable pumping rates and one production well that was represented in the simulation during 2015 Base Case but was inactive during 2004. Simulated water levels (and changes) indicate water-level rises in Glynn County, corresponding to a decrease in pumping during this period, with the exception of the Brunswick aquifer system (layers 3 and 5), which had similar pumping rates from 2004 to 2015.

Simulated horizontal potentiometric gradients for the 2015 Base Case approximated observed gradients in the five potentiometric profiles $\left(A-A^{\prime}\right.$ to $\left.E-E^{\prime}\right)$ that were constructed in close proximity to the chloride plume (fig. 13). Waterlevel data available for well 33H211 allowed the 2004 potentiometric profiles to be constructed in close proximity to the Brunswick Cellulose well field. Water-level data were not available for well 33H211 during October 2015, but the simulated head allowed a comparison to the 2004 potentiometric profiles (fig. 13; table 6). The simulated heads for the 2015 Base Case and the constructed profiles $\left(A-A^{\prime}\right.$ to $E-E^{\prime}$ ) show substantially higher heads as a result of lower pumping rates. The simulated head differences were calculated using the simulated heads at the endpoints for each of the profiles (table 7). For the 2004 simulation, higher pumping rates yield simulated head differences that range between 8.64 and $12.4 \mathrm{ft}$. In profiles $A-A^{\prime}$ to $D-D^{\prime}$, simulated potentiometric gradients range between 7.6 and $11.0 \mathrm{ft} / \mathrm{mi}$ near the Brunswick Cellulose well field and $3.6 \mathrm{ft} / \mathrm{mi}$ in profile $E-E^{\prime}$ oriented in a general north to south direction. The lower pumping rates for the 2015 Base Case simulation, in general, reduce the cone of depression near pumping centers and decrease simulated head differences along the profiles, which range from 7.70 to $9.42 \mathrm{ft}$. The simulated potentiometric gradients for the 2015 Base Case range between 6.7 and $9.8 \mathrm{ft} / \mathrm{mi}$ in profiles $A-A^{\prime}$ to $D-D^{\prime}$ located near the Brunswick Cellulose well field and $2.8 \mathrm{ft} / \mathrm{mi}$ in profile $E-E^{\prime}$.

\section{Simulated Water Budget}

The simulated 2004 and 2015 Base Case water budgets consist of the following major components of inflow and outflow to the groundwater-flow system: (1) inflow from the general-head boundaries, (2) inflow across county boundaries, (3) outflow to the general-head boundary, (4) discharge to wells, and (5) outflow across county boundaries. The 2004 and 2015 Base Case flows were characterized using the MODFLOW postprocessor ZONEBUDGET (Harbaugh, 1990). Flow calculations were summarized by model layer and by zone within each layer. 

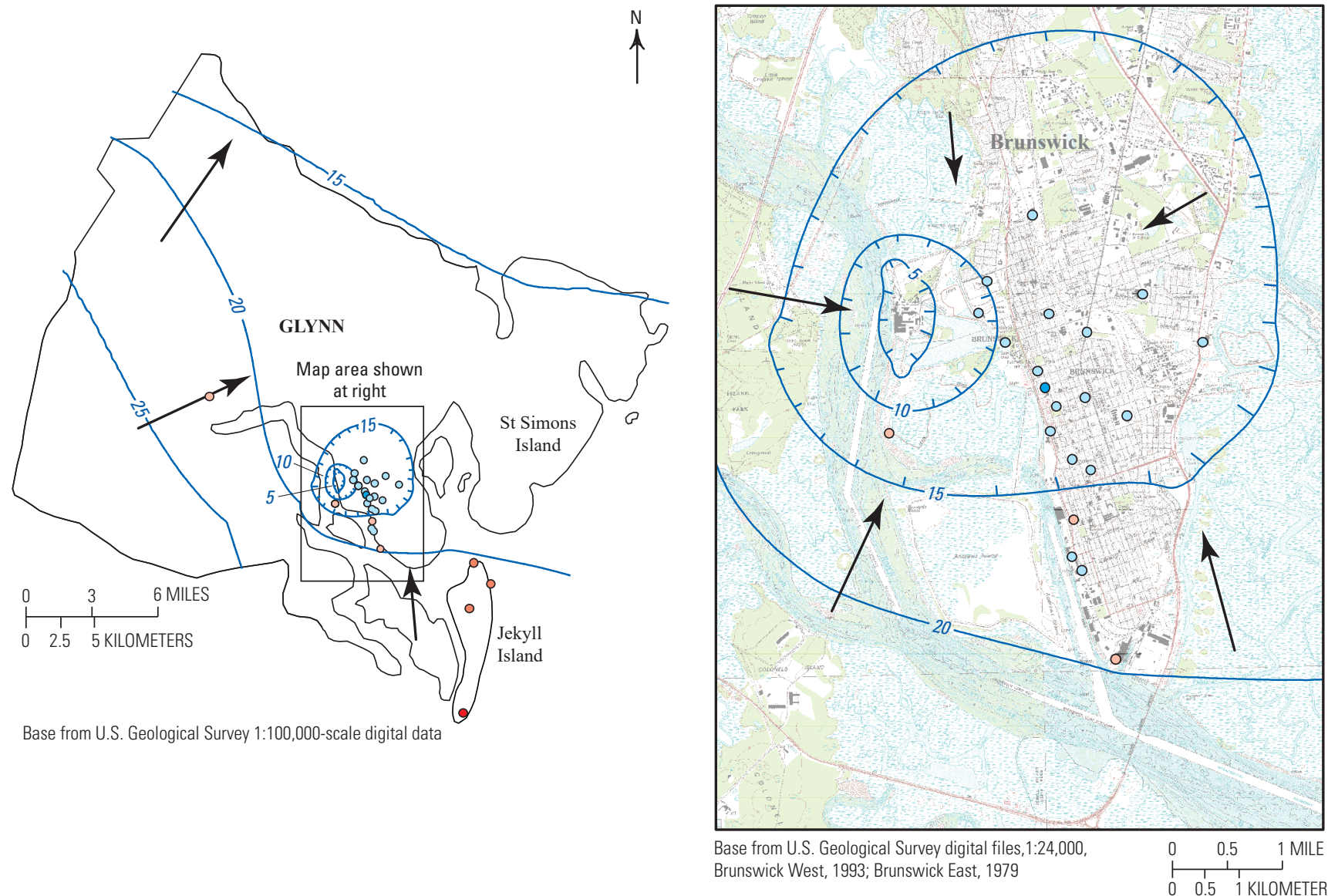

EXPLANATION

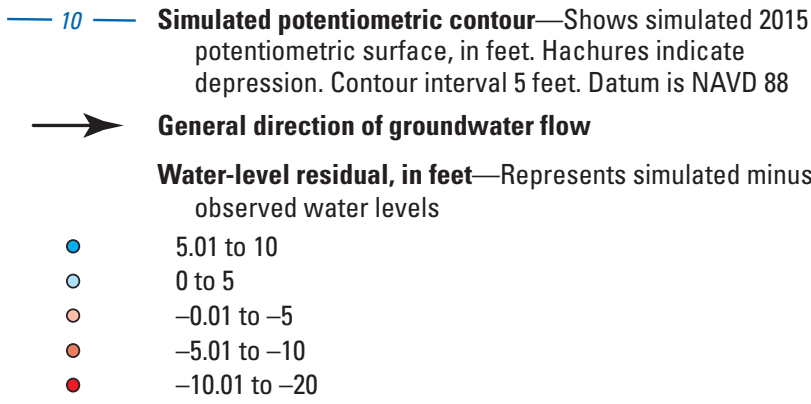

Figure 11. Maps showing simulated 2015 Base Case potentiometric surfaces and water-level residuals for model layer 7 , upper waterbearing zone of the Upper Floridan aquifer, Glynn County and Brunswick area (enlargement), Georgia.

An analysis similar to that described for general-head boundaries in the Brunswick/Glynn County area indicates that specified-head boundaries located along the southern and southwestern model boundaries contribute greatly to the water budget (fig. 7). In the Brunswick/Glynn County area, simulated pumping totaled 55.2 Mgal/d during 2004 and 45.2 Mgal/d during 2015 Base Case. Outflows to the generalhead boundary in model layer 1 of 5.8 and $6.3 \mathrm{Mgal} / \mathrm{d}$ (for simulated 2004 and 2015 Base Case conditions, respectively) exceeded inflows of 0.21 along the same boundary (fig. 14; table 8). For the 2004 simulation, $19.6 \mathrm{Mgal} / \mathrm{d}$ of pumping was assigned to model layer 7 (UWBZ of UFA) and $34.1 \mathrm{Mgal} / \mathrm{d}$ to model layer 9 (LWBZ of UFA). For the 2015 Base Case simulation, a determination was made to assign greater pumping of $31.2 \mathrm{Mgal} / \mathrm{d}$ to model layer 7 on the basis of depth of production wells in the study area. An additional 12.4 Mgal/d of pumping was assigned to model layer 9 on the basis of well information that includes five production wells that tap the LWBZ of the UFA. 


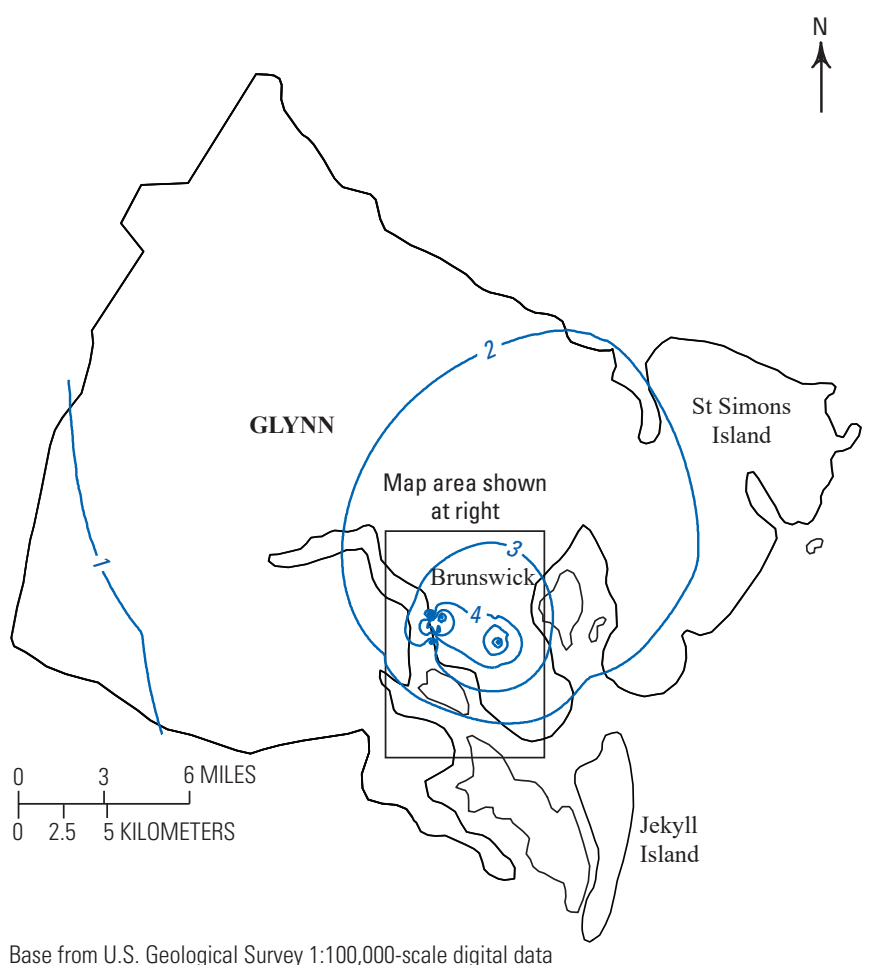

Base from U.S. Geological Survey 1:100,000-scale digital data

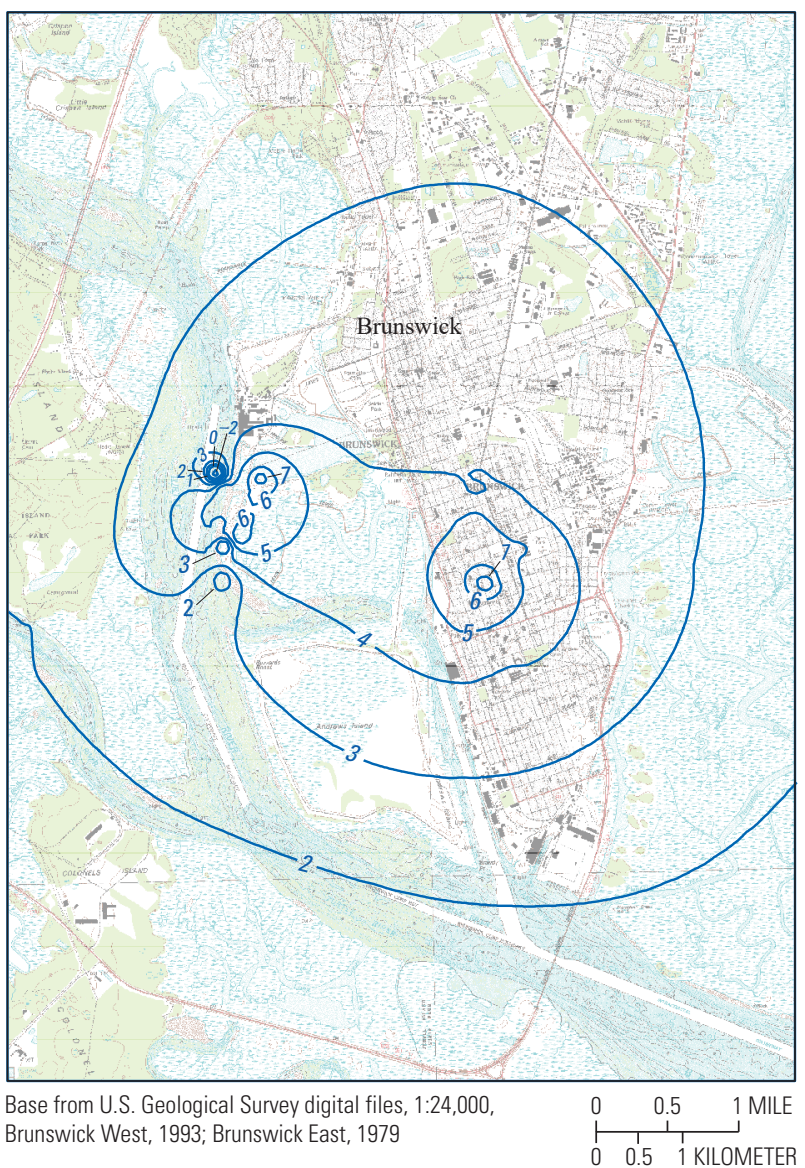

Base from U.S. Geological Survey digital files, 1:24,000

Brunswick West, 1993; Brunswick East, 1979

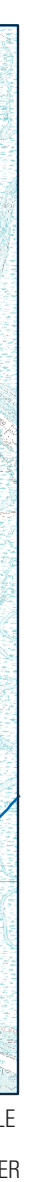

EXPLANATION
- 10 - Simulated water-level change-Computed by subtracting simulated potentiometric surface for 2004 from simulated potentiometric surface for 2015. Contour interval 1 foot

Figure 12. Maps showing simulated water-level change from 2004 to 2015 Base Case for model layer 7, upper water-bearing zone of Upper Floridan aquifer in the Brunswick/Glynn County area in Georgia. 

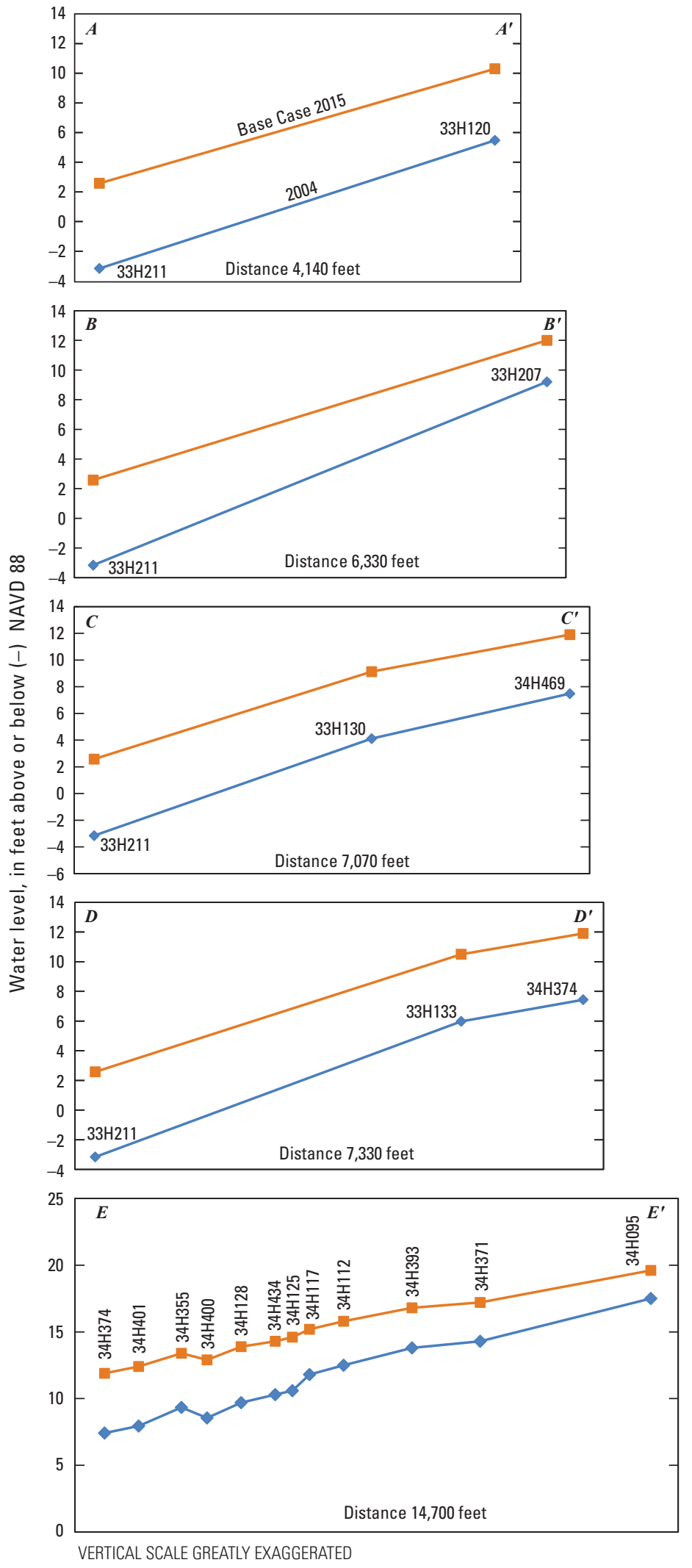

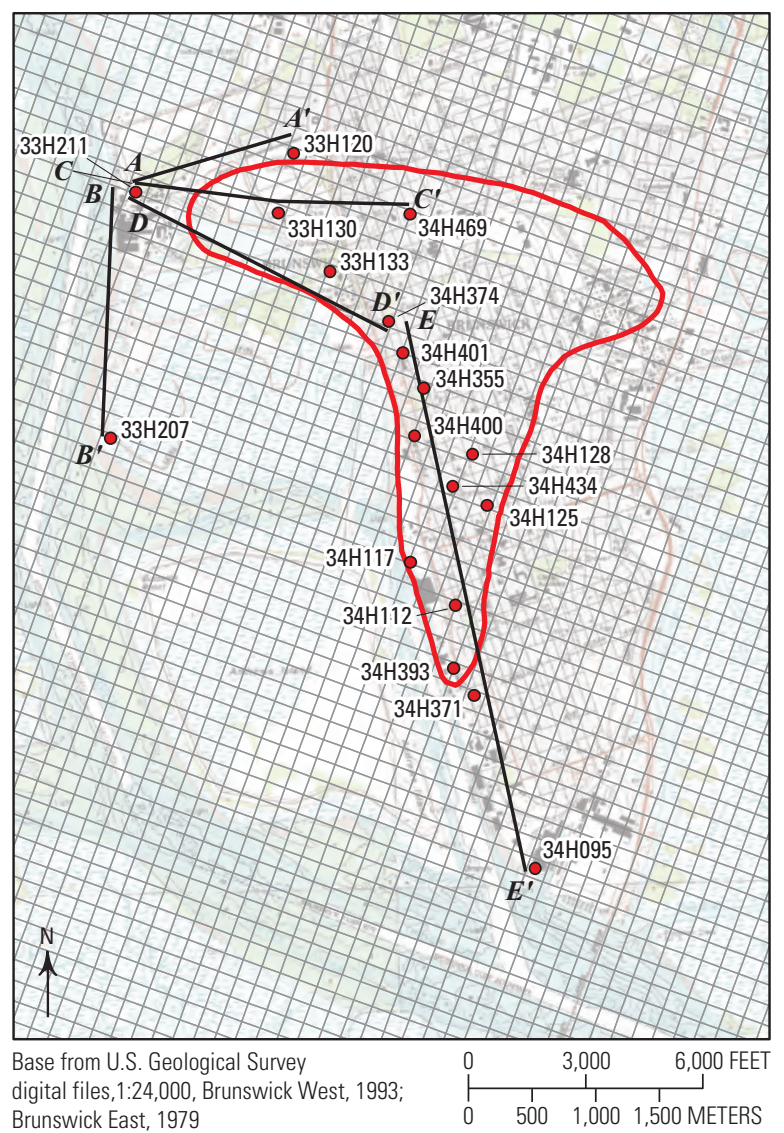

Brunswick East, 1979

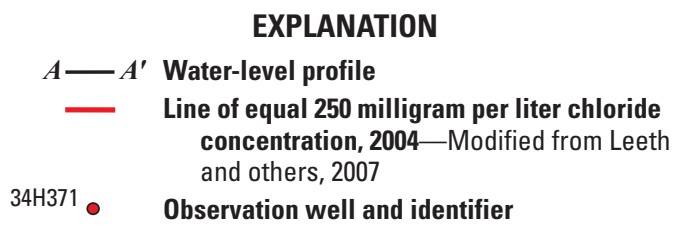

Figure 13. Graphs showing simulated potentiometric profiles near the chloride plume in the Upper Floridan aquifer near downtown Brunswick, Georgia, during 2004 and 2015 Base Case. 
Table 6. Simulated and observed groundwater levels and water-level changes, 2004 and 2015 Base Case, for model layer 7, upper water-bearing zone of the Upper Floridan aquifer in the Brunswick/Glynn County area, Georgia.

[Simulated and observed groundwater levels are above or below (-) NAVD 88; observed values for 2004 are during June; observed values for 2015 are during October; see fig. 1-1 for well locations; - - no data]

\begin{tabular}{|c|c|c|c|c|c|c|}
\hline \multirow{3}{*}{$\begin{array}{l}\text { Well } \\
\text { identifier }\end{array}$} & \multicolumn{4}{|c|}{ Groundwater levels, in feet } & \multirow{2}{*}{\multicolumn{2}{|c|}{$\frac{\text { Water-level change, in feet }}{2015 \text { minus } 2004}$}} \\
\hline & \multicolumn{2}{|c|}{2004 calibration } & \multicolumn{2}{|c|}{2015 Base Case calibration } & & \\
\hline & Simulated & Observed & Simulated & Observed & Simulated & Observed \\
\hline $33 \mathrm{G} 002$ & 22.40 & 23.48 & 23.70 & - & 1.30 & - \\
\hline $33 \mathrm{G} 008$ & 22.20 & 23.16 & 23.60 & - & 1.40 & - \\
\hline $33 \mathrm{G} 024$ & 24.20 & 29.87 & 25.40 & - & 1.20 & - \\
\hline $33 \mathrm{H} 120$ & 5.48 & 3.08 & 10.30 & 7.98 & 4.82 & 4.90 \\
\hline $33 \mathrm{H} 130$ & 4.12 & 2.18 & 9.13 & 6.83 & 5.01 & 4.65 \\
\hline $33 \mathrm{H} 133$ & 5.97 & 3.77 & 10.50 & 8.20 & 4.53 & 4.43 \\
\hline $33 \mathrm{H} 177$ & 23.90 & 28.20 & 25.10 & - & 1.20 & - \\
\hline $33 \mathrm{H} 180$ & 9.20 & - & 13.00 & 10.10 & 3.80 & - \\
\hline $33 \mathrm{H} 193$ & 20.50 & 22.38 & 22.10 & 24.95 & 1.60 & 2.57 \\
\hline $33 \mathrm{H} 207$ & 9.21 & 8.09 & 12.00 & 13.30 & 2.79 & 5.21 \\
\hline $33 \mathrm{H} 211$ & -3.16 & -4.16 & 2.58 & - & 5.74 & - \\
\hline $33 \mathrm{H} 213$ & -0.19 & -1.72 & 5.23 & - & 5.42 & - \\
\hline $34 \mathrm{G} 002$ & 17.90 & 22.40 & 20.00 & - & 2.10 & - \\
\hline 34G003 & 21.60 & 25.90 & 23.00 & - & 1.40 & - \\
\hline 34G009 & 21.30 & 38.70 & 22.50 & 39.77 & 1.20 & 1.07 \\
\hline $34 \mathrm{G} 016$ & 19.40 & 28.30 & 20.80 & 28.80 & 1.40 & 0.50 \\
\hline $34 \mathrm{G} 017$ & 18.70 & 26.10 & 20.30 & 26.30 & 1.60 & 0.20 \\
\hline $34 \mathrm{G} 020$ & 20.60 & 30.10 & 21.90 & 31.10 & 1.30 & 1.00 \\
\hline $34 \mathrm{H} 062$ & 8.54 & - & 13.10 & 11.40 & 4.56 & - \\
\hline 34H095 & 17.50 & 17.90 & 19.60 & 20.50 & 2.10 & 2.60 \\
\hline $34 \mathrm{H} 112$ & 12.50 & 12.90 & 15.80 & 15.90 & 3.30 & 3.00 \\
\hline $34 \mathrm{H} 117$ & 11.80 & 10.50 & 15.20 & - & 3.40 & - \\
\hline $34 \mathrm{H} 125$ & 10.60 & 12.40 & 14.60 & 11.80 & 4.00 & -0.60 \\
\hline $34 \mathrm{H} 128$ & 9.70 & 8.13 & 13.90 & - & 4.20 & - \\
\hline 34H344 & 7.68 & 6.22 & 13.20 & - & 5.52 & - \\
\hline 34H355 & 9.34 & 8.46 & 13.40 & 12.50 & 4.06 & 4.04 \\
\hline $34 \mathrm{H} 371$ & 14.30 & 15.50 & 17.20 & 16.20 & 2.90 & 0.70 \\
\hline $34 \mathrm{H} 373$ & 8.37 & 3.98 & 13.10 & 8.81 & 4.73 & 4.83 \\
\hline $34 \mathrm{H} 374$ & 7.43 & 7.20 & 11.90 & 10.00 & 4.47 & 2.80 \\
\hline 34H393 & 13.80 & 14.60 & 16.80 & 16.70 & 3.00 & 2.10 \\
\hline $34 \mathrm{H} 400$ & 8.56 & 4.34 & 12.90 & 8.07 & 4.34 & 3.73 \\
\hline $34 \mathrm{H} 401$ & 7.95 & 2.53 & 12.40 & 6.92 & 4.45 & 4.39 \\
\hline $34 \mathrm{H} 424$ & 7.86 & - & 12.60 & 12.40 & 4.74 & - \\
\hline $34 \mathrm{H} 434$ & 10.30 & 6.13 & 14.30 & 12.60 & 4.00 & 6.47 \\
\hline $34 \mathrm{H} 469$ & 7.48 & 6.61 & 11.90 & 11.50 & 4.42 & 4.89 \\
\hline $34 \mathrm{H} 514$ & 8.50 & - & 13.60 & 12.60 & 5.10 & - \\
\hline $34 \mathrm{H} 552$ & 8.99 & - & 13.30 & 10.40 & 4.31 & - \\
\hline
\end{tabular}




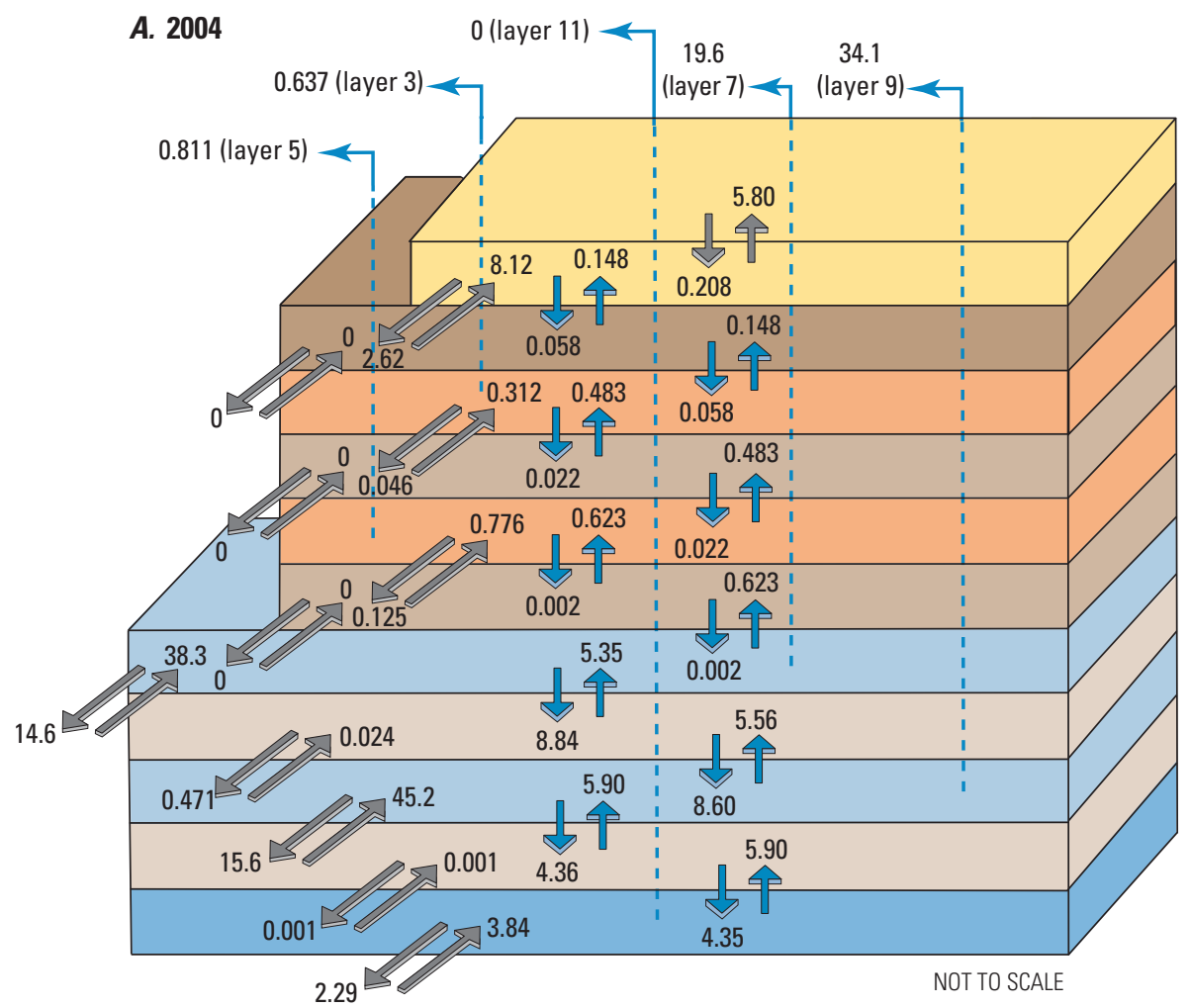

Surficial aquifer system (layer 1)

Brunswick aquifer system confining unit (layer 2)

Upper Brunswick aquifer (layer 3)

Lower Brunswick confining unit (layer 4)

Lower Brunswick aquifer (layer 5)

Upper Floridan confining unit (layer 6)

Upper water-bearing zone Upper Floridan aquifer (layer 7)

Lower water-bearing zone Upper Floridan confining unit (layer 8)

Lower water-bearing zone Upper Floridan aquifer (layer 9)

Lower Floridan confining unit (layer 10)

Lower Floridan aquifer (layer 11)
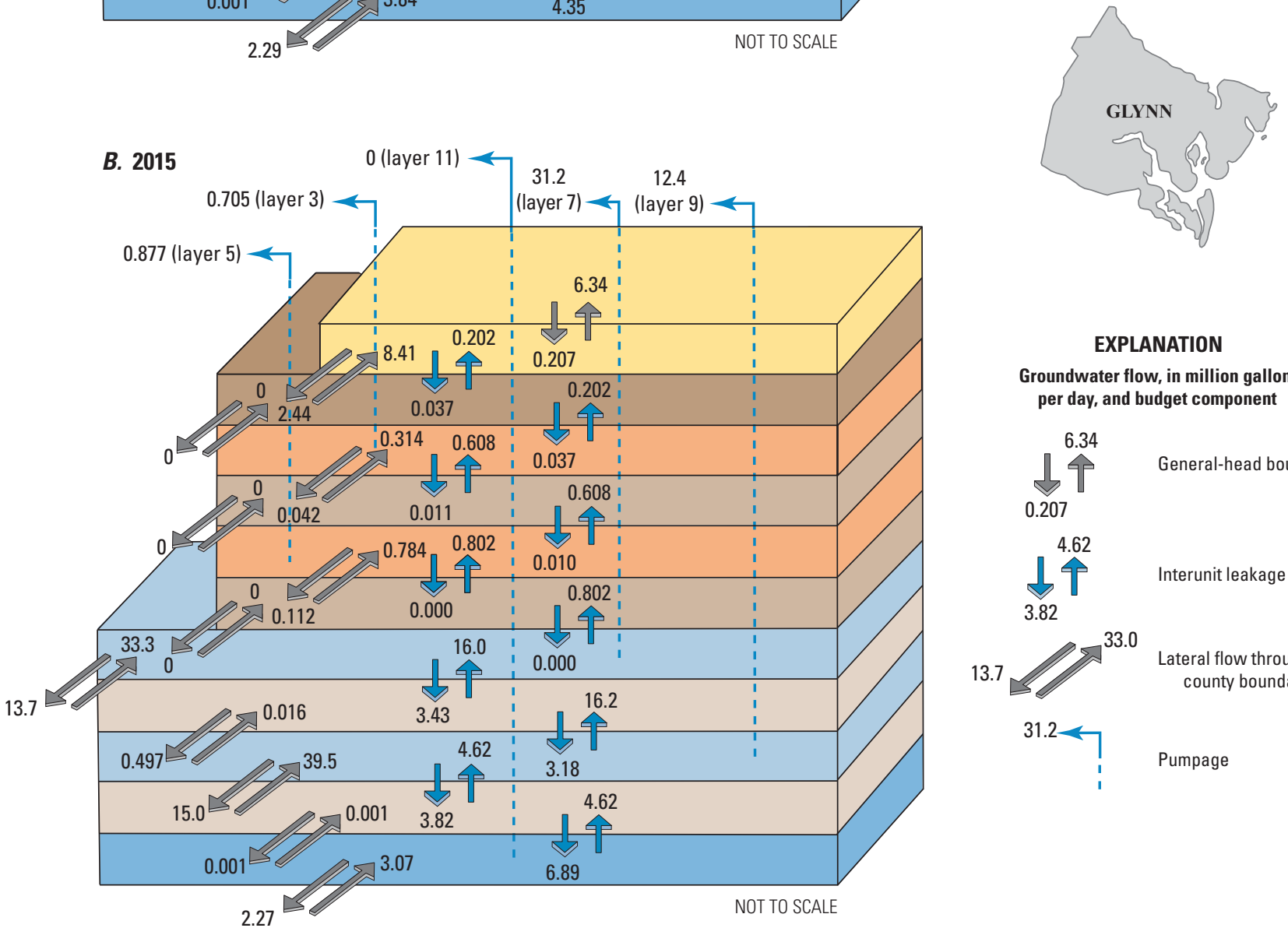

EXPLANATION

Groundwater flow, in million gallons per day, and budget component

6.34

$\checkmark 5$

General-head boundary

0.207

4.62

Interunit leakage

3.82

13.7

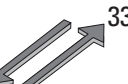

Lateral flow through county boundary

$31.2<$

Pumpage

Figure 14. Schematic diagram showing simulated water budgets in Glynn County, Georgia, during (A) 2004 and (B) 2015 Base Case. 
Table 7. Simulated head difference and horizontal potentiometric gradients for 2004 and 2015 Base Case along profiles $A-A^{\prime}, B-B^{\prime}$, $C-C^{\prime}, D-D^{\prime}$, and $E-E^{\prime}$ in the upper water-bearing zone of the Upper Floridan aquifer in the downtown area of Brunswick, Georgia.

[Horizontal hydraulic-head gradients calculated using simulated heads at the endpoints of profile; see fig. 13 for location of profiles]

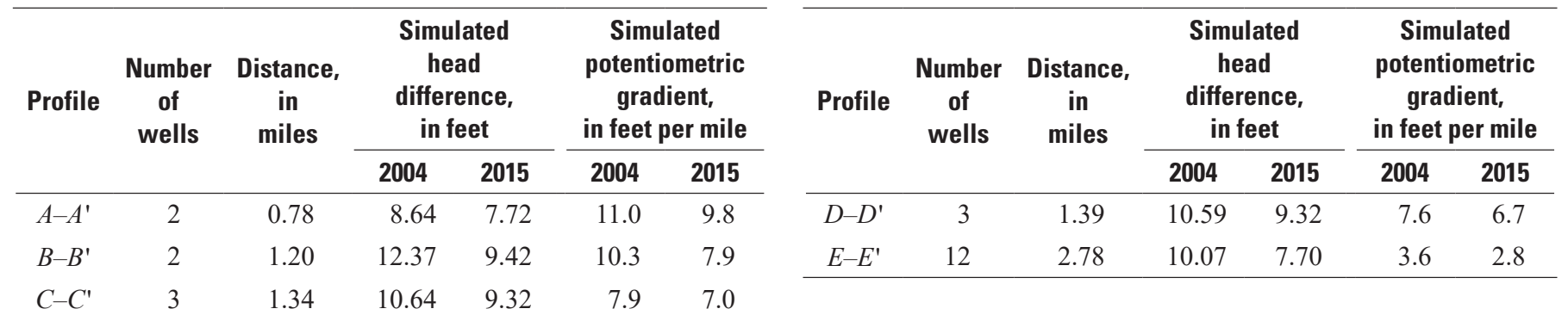

Table 8. Flow-budget components for 2004 and 2015 Base Case in the Brunswick/Glynn County area of Georgia.

[Results from MODFLOW model; all values in million gallons per day; - , not applicable]

\begin{tabular}{|c|c|c|c|c|c|c|c|}
\hline $\begin{array}{c}\text { Model } \\
\text { layer }\end{array}$ & $\begin{array}{c}\text { From } \\
\text { general-head } \\
\text { boundary, } \\
\text { onshore }\end{array}$ & $\begin{array}{c}\text { Across } \\
\text { county } \\
\text { boundaries }\end{array}$ & Total & $\begin{array}{c}\text { To } \\
\text { general-head } \\
\text { boundary, } \\
\text { onshore }\end{array}$ & $\begin{array}{c}\text { Across } \\
\text { county } \\
\text { boundaries }\end{array}$ & $\begin{array}{c}\text { Discharge } \\
\text { to } \\
\text { wells }\end{array}$ & Total \\
\hline \multicolumn{4}{|c|}{2004 inflow } & \multicolumn{4}{|c|}{2004 outflow } \\
\hline 1 & 0.21 & 8.12 & 8.33 & 5.80 & 2.62 & - & 8.42 \\
\hline 2 & - & - & - & - & - & - & - \\
\hline 3 & - & 0.31 & 0.31 & - & 0.05 & 0.64 & 0.69 \\
\hline 4 & - & - & - & - & - & - & - \\
\hline 5 & - & 0.78 & 0.78 & - & 0.12 & 0.81 & 0.93 \\
\hline 6 & - & - & - & - & - & - & - \\
\hline 7 & - & 38.31 & 38.31 & - & 14.56 & 19.64 & 34.20 \\
\hline 8 & - & 0.02 & 0.02 & - & 0.47 & - & 0.47 \\
\hline 9 & - & 45.19 & 45.19 & - & 15.64 & 34.14 & 49.78 \\
\hline 10 & - & - & - & - & - & - & - \\
\hline 11 & - & 3.84 & 3.84 & - & 2.29 & 0.00 & 2.29 \\
\hline Total, all units & 0.21 & 96.57 & 96.78 & 5.80 & 35.75 & 55.23 & 96.78 \\
\hline Percentage of total flow & 0.2 & 99.8 & 100.0 & 6.0 & 36.9 & 57.1 & 100.0 \\
\hline \multicolumn{4}{|c|}{2015 Base Case inflow } & \multicolumn{4}{|c|}{2015 Base Case outflow } \\
\hline 1 & 0.21 & 8.42 & 8.63 & 6.34 & 2.44 & - & 8.78 \\
\hline 2 & - & - & - & - & - & - & - \\
\hline 3 & - & 0.31 & 0.31 & - & 0.04 & 0.71 & 0.75 \\
\hline 4 & - & - & - & - & - & - & - \\
\hline 5 & - & 0.78 & 0.78 & - & 0.11 & 0.88 & 0.99 \\
\hline 6 & - & - & - & - & - & - & - \\
\hline 7 & - & 33.26 & 33.26 & - & 13.74 & 31.23 & 44.97 \\
\hline 8 & - & 0.02 & 0.02 & - & 0.50 & - & 0.50 \\
\hline 9 & - & 39.53 & 39.53 & - & 14.95 & 12.38 & 27.33 \\
\hline 10 & - & - & - & - & - & - & - \\
\hline 11 & - & 3.07 & 3.07 & - & 2.27 & 0.00 & 2.27 \\
\hline Total, all units & 0.21 & 85.39 & 85.60 & 6.34 & 34.05 & 45.20 & 85.59 \\
\hline Percentage of total flow & 0.2 & 99.8 & 100.0 & 7.4 & 39.8 & 52.8 & 100.0 \\
\hline
\end{tabular}




\section{Groundwater-Management Scenarios}

The revised model is used primarily to simulate groundwater flow in close proximity to pumping centers located near the area of chloride contamination in the city of Brunswick. The grid of the original model was refined to finer resolution in these areas to evaluate simulated horizontal-head gradients and cones of depressions near pumping centers. As a 2015 Base Case simulation for the current study, the revised model was updated to include pumping rates during October 2015 for selected production wells in the Brunswick/ St. Simons Island area (fig. 15; table 9). The time of the 2015 Base Case simulation period was selected because of availability of water-level measurements during October 2015 in the Brunswick/Glynn County area. The model calibration of the 2015 Base Case simulation is a good indicator that residuals (simulated heads minus observed heads) are within reasonable ranges to allow further evaluation of a variety of groundwater-management scenarios. The focus of the scenarios is the addition of pumping for new hypothetical wells in areas of projected growth along with adjustments in pumping rates for existing production wells and evaluation of simulated changes in hydraulic head (water levels) and hydraulic-head gradients near the chloride plume. Previous analyses for the original and revised model determined that simulated heads are most sensitive to changes in pumping rates followed by changes in horizontal hydraulic conductivity (Payne and others, 2005; Cherry, 2015). Calibration of the 2015 Base Case using residuals confirms model sensitivity to changes in pumping because no other changes were made. Horizontal and vertical hydraulic-head gradients determine local groundwater-flow directions and influence rates of groundwater movement and possible migration of the chloride plume.

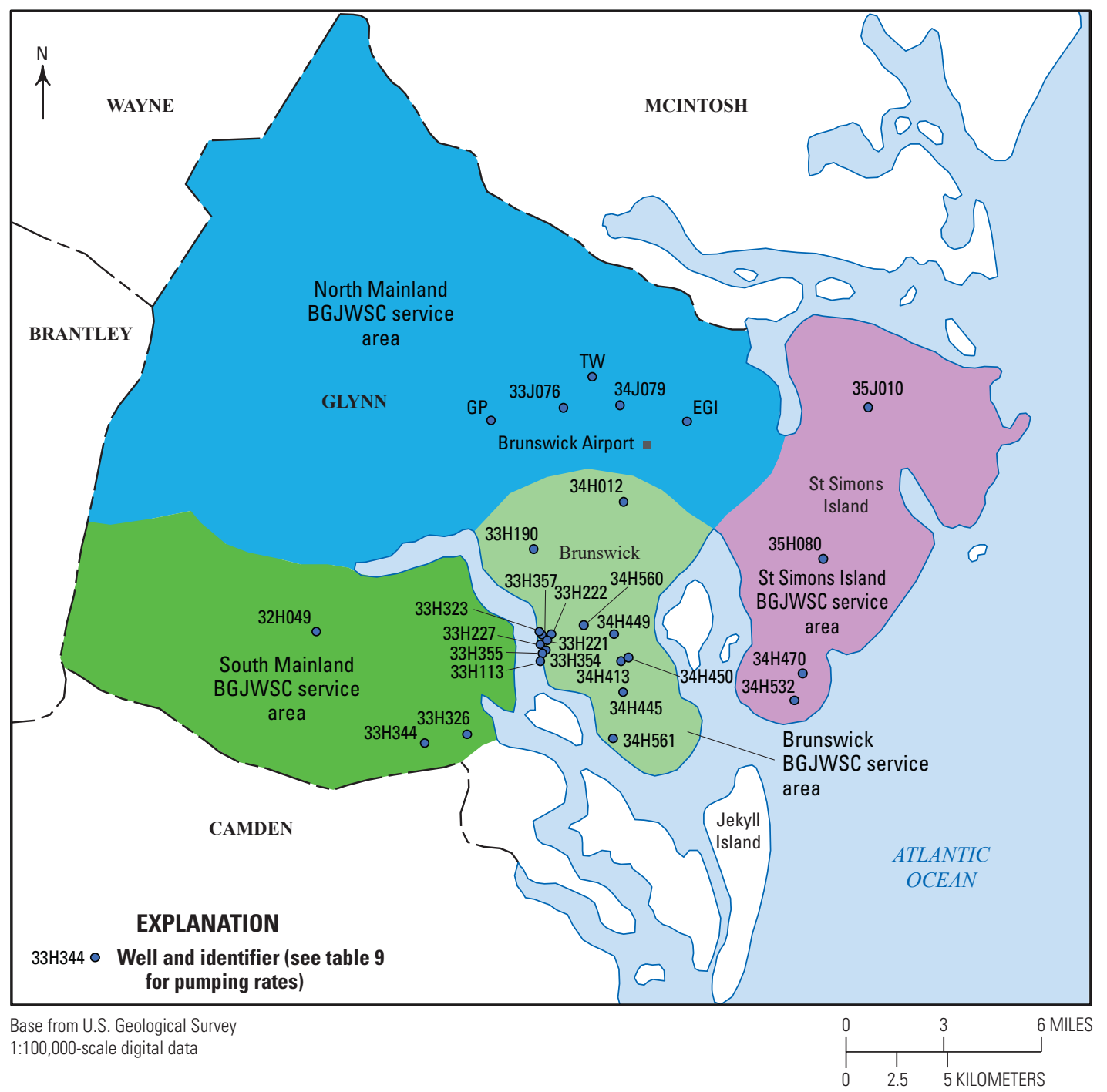

Figure 15. Map showing location of Brunswick-Glynn County Joint Water and Sewer Commission service areas (shaded) and production wells used for the 2015 Base Case simulation and groundwater-management scenarios. 
Table 9. Simulated pumping at selected production wells for the 2015 Base Case simulation and model Scenarios A-E.

[BAS, Brunswick aquifer system; Brunswick Cellulose, formerly Brunswick Pulp \& Paper Company; BGJWSC, Brunswick-Glynn County Joint Water and Sewer Commission; Pinova, Pinova Inc.-formerly Hercules Inc.; LWBZ, lower water-bearing zone of Upper Floridan aquifer (UFA); SSI, St. Simons Island; UWBZ, upper water-bearing zone of UFA; - , not applicable; *, pumping rates adjusted from Scenario D1 (12.5 percent), Scenario D2 (25 percent), and Scenario D3 (50 percent) of 2015 Base Case amount; see figure 15 for well locations]

\begin{tabular}{|c|c|c|c|c|c|c|c|c|c|c|}
\hline \multirow{3}{*}{$\begin{array}{c}\text { Well } \\
\text { identifier }\end{array}$} & \multirow{3}{*}{ Well name } & \multirow{3}{*}{ Aquifer } & Latitude & Longitude & \multirow{3}{*}{$\begin{array}{l}2015 \\
\text { Base } \\
\text { Case }\end{array}$} & \multirow{2}{*}{\multicolumn{5}{|c|}{$\begin{array}{c}\text { Simulated pumping rate, in million } \\
\text { gallons per day } \\
\text { Scenario }\end{array}$}} \\
\hline & & & \multirow{2}{*}{\multicolumn{2}{|c|}{$\begin{array}{l}\text { Decimal degrees } \\
\text { (NAD 83) }\end{array}$}} & & & & & & \\
\hline & & & & & & A & B & C & D1-D3 & E \\
\hline \multicolumn{11}{|c|}{ North Mainland service area } \\
\hline $34 \mathrm{~J} 079$ & BGJWSC Golden Isles 1 & BAS & 31.278139 & -81.476972 & 0.301 & 0.301 & 0.301 & 0.301 & 0.301 & 0.301 \\
\hline 33J076 & BGJWSC Golden Isles 2 & BAS & 31.277681 & -81.506469 & 0.229 & 0.229 & 0.229 & 0.229 & 0.229 & 0.229 \\
\hline TW & BGJWSC Tradewinds/Altma & UWBZ & 31.291086 & -81.491107 & 0.000 & 0.750 & 0.750 & 0.000 & 0.000 & 0.000 \\
\hline EGI & BGJWSC Eastgate/Golden Isles & UWBZ & 31.270275 & -81.442528 & 0.000 & 0.000 & 0.750 & 0.000 & 0.000 & 0.000 \\
\hline GP & BGJWSC Georgia Pacific & UWBZ & 31.272625 & -81.544322 & 0.000 & 0.000 & 0.750 & 0.000 & 0.000 & 0.000 \\
\hline \multicolumn{11}{|c|}{ City of Brunswick service area } \\
\hline $34 \mathrm{H} 012$ & BGJWSC FLETC & UWBZ & 31.235278 & -81.476111 & 0.437 & 0.911 & 1.197 & 0.437 & 0.437 & 0.437 \\
\hline 33H190 & BGJWSC I-95 & UWBZ & 31.215167 & -81.523556 & 0.801 & 1.275 & 0.981 & 0.801 & 0.801 & 0.801 \\
\hline $34 \mathrm{H} 560$ & BGJWSC Brunswick Villa & UWBZ & 31.180889 & -81.498528 & 0.947 & 0.000 & 0.769 & 0.947 & 0.947 & 0.947 \\
\hline $34 \mathrm{H} 449$ & BGJWSC Goodyear Park & UWBZ & 31.176528 & -81.482750 & 0.790 & 0.790 & 1.290 & 0.790 & 0.790 & 0.790 \\
\hline $33 \mathrm{H} 323$ & Brunswick Cellulose 4 & UWBZ & 31.178394 & -81.521406 & 6.650 & 6.650 & 6.650 & 0.000 & $1.662 *$ & 6.650 \\
\hline $33 \mathrm{H} 222$ & Brunswick Cellulose 7 & UWBZ/LWBZ & 31.177006 & -81.515242 & 0.730 & 0.730 & 0.730 & 0.000 & $0.182 *$ & 0.730 \\
\hline $33 \mathrm{H} 221$ & Brunswick Cellulose 8 & UWBZ/LWBZ & 31.174328 & -81.517444 & 5.860 & 5.860 & 5.860 & 0.000 & $1.465^{*}$ & 5.860 \\
\hline $33 \mathrm{H} 227$ & Brunswick Cellulose 1 & UWBZ & 31.172564 & -81.521014 & 3.200 & 3.200 & 3.200 & 0.000 & $0.800 *$ & 3.200 \\
\hline $33 \mathrm{H} 354$ & Brunswick Cellulose 2 & UWBZ/LWBZ & 31.169950 & -81.518172 & 1.030 & 1.030 & 1.030 & 0.000 & $0.258^{*}$ & 1.030 \\
\hline $33 \mathrm{H} 355$ & Brunswick Cellulose 5 & UWBZ & 31.168600 & -81.520194 & 5.950 & 5.950 & 5.950 & 0.000 & $1.488^{*}$ & 5.950 \\
\hline $33 \mathrm{H} 113$ & Brunswick Cellulose 6 & UWBZ/LWBZ & 31.165217 & -81.521147 & 4.520 & 4.520 & 4.520 & 0.000 & $1.130^{*}$ & 4.520 \\
\hline $33 \mathrm{H} 357$ & Brunswick Cellulose 3 (new) & UWBZ & 31.176996 & -81.520088 & 0.000 & 0.000 & 0.000 & 0.000 & 0.000 & 5.000 \\
\hline $34 \mathrm{H} 450$ & Pinova V & UWBZ & 31.166114 & -81.475419 & 1.410 & 1.410 & 1.410 & 0.000 & $0.352 *$ & 1.410 \\
\hline 34H413 & Pinova S & UWBZ/LWBZ & 31.164433 & -81.479314 & 2.000 & 2.000 & 2.000 & 0.000 & $0.500^{*}$ & 2.000 \\
\hline $34 \mathrm{H} 445$ & BGJWSC Howard Coffin Park & UWBZ & 31.150667 & -81.478583 & 0.730 & 0.730 & 1.230 & 0.730 & 0.730 & 0.730 \\
\hline 34H561 & King \& Prince Seafood & UWBZ & 31.130194 & -81.484500 & 0.110 & 0.110 & 0.110 & 0.110 & 0.110 & 0.110 \\
\hline \multicolumn{11}{|c|}{ St. Simons Island service area } \\
\hline $35 \mathrm{~J} 010$ & BGJWSC Hampton South & UWBZ & 31.274833 & -81.347694 & 0.040 & 0.040 & 0.400 & 0.040 & 0.040 & 0.040 \\
\hline $35 \mathrm{H} 080$ & BGJWSC Harrington & UWBZ & 31.208083 & -81.373167 & 0.630 & 0.630 & 0.980 & 0.630 & 0.630 & 0.630 \\
\hline $34 \mathrm{H} 470$ & BGJWSC SSI Airport & UWBZ & 31.157306 & -81.385083 & 1.016 & 1.016 & 1.016 & 1.016 & 1.016 & 1.016 \\
\hline 34H532 & BGJWSC Mallory & UWBZ & 31.145306 & -81.389583 & 0.856 & 0.856 & 0.856 & 0.856 & 0.856 & 0.856 \\
\hline \multicolumn{11}{|c|}{ South Mainland service area } \\
\hline $32 \mathrm{H} 049$ & BGJWSC Brookman & UWBZ & 31.180389 & -81.637500 & 0.000 & 0.000 & 0.790 & 0.000 & 0.000 & 0.000 \\
\hline $33 \mathrm{H} 326$ & BGJWSC Fancy Bluff & BAS & 31.133278 & -81.560222 & 0.252 & 0.252 & 0.252 & 0.252 & 0.252 & 0.252 \\
\hline 33H344 & BGJWSC Exit-29 Southport & UWBZ & 31.129889 & -81.582194 & 0.001 & 0.001 & 0.790 & 0.001 & 0.001 & 0.001 \\
\hline
\end{tabular}

Data sources: 2015 Base Case pumping rates were obtained to estimate groundwater withdrawal from the Upper Floridan aquifer during

October 2015. B. Simmons (Brunswick/Glynn County Joint Water and Sewer Commission, written commun., 2015) provided estimates for BGJWSC public-supply wells. J.H. Dickens (Brunswick Cellulose Inc., written commun., 2017) provided estimates for industrial wells located at Brunswick Cellulose. M.A. Gray (Pinova Inc., written commun., 2017) provided estimates for industrial wells located at Pinova. 
The revised calibrated 2015 Base Case regional model with local grid refinement was used to simulate the potential effect of seven distinct pumping scenarios on local groundwater flow in the Brunswick/St. Simons Island area. Alteration of hydraulic-head gradients near the chloride plume could change local groundwater-flow directions and allow solute movement toward nearby public-supply wells. The 2015 Base Case simulation represents local pumping rates during October 2015 calibrated by comparison of simulated to observed heads. In addition, the 2015 Base Case simulation is used as the basis to assess changes to the groundwater-flow system for each of the seven groundwatermanagement scenarios. Two scenarios (Scenarios A and B) simulate additional pumping at existing public-supply wells located near the chloride plume with the addition of planned public-supply wells located to the north of Brunswick. Scenario $\mathrm{C}$ simulates the event of a shutdown at two industrial facilities (Brunswick Cellulose and Pinova) and the resulting deactivation of nine production wells pumping a total of 31.3 Mgal/d during 2015. Scenario D (three scenarios) simulates $12.5,25$, and 50 percent (designated D1, D2, and D3, respectively) of the $31.3 \mathrm{Mgal} / \mathrm{d} 2015$ Base Case pumping rates at Brunswick Cellulose and Pinova. This scenario can help determine pumping rates that may reverse horizontal hydraulic-head gradients toward pumping centers and allow groundwater flow across the Brunswick peninsula in a northeasterly direction. Scenario E simulates an additional $5 \mathrm{Mgal} / \mathrm{d}$ of pumping at a recently constructed production well within the Brunswick Cellulose well field.

\section{Scenario A}

Scenario A simulates deactivation of the Brunswick Villa public-supply well (34H560) and redistribution of the pumping rate between two nearby public-supply wells (33H190 and 34H012). Scenario A simulates projected water demand to the year 2020 on the basis of anticipated growth in the North Mainland service area. The Brunswick Villa production well (34H560) is located outside the chloride plume area in the northern part of Brunswick (fig. $1 B$ ) and is influenced by pumping at the Brunswick Cellulose well field. The Brunswick Villa well was constructed in 1943 and originally tapped the UWBZ and LWBZ of the UFA (Cherry and others, 2011). Chloride concentrations steadily increased in the well from near background levels (20 to $30 \mathrm{mg} / \mathrm{L})$ during June 2000 (32.0 mg/L) to $96 \mathrm{mg} / \mathrm{L}$ during October 2015 (Cherry and Peck, 2017). Modifications were made to the well in July 2015 to reduce water inflow from the deeper part of the aquifer. The bottom of the well, depths of 942-724 ft, was sealed with concrete grout, thereby eliminating water production from a $218-\mathrm{ft}$ zone that yields higher chloride water. This approach effectively lowered the chloride concentration for a short period, but then the increases in chloride concentrations continued, which was an indication of either lateral movement of chloride in the UWBZ from the plume or the continued upward migration of chloride from the LWBZ. The BGJWSC recommended, as part of its Water and Sewer Master Plan Update 2015-2035, decommissioning the Brunswick Villa production well by 2020 (Applied Technology \& Management, 2016). Scenario A simulates redistribution of pumping from the Brunswick Villa well (34H560; $0.947 \mathrm{Mgal} / \mathrm{d})$ between I-95 and the Federal Law Enforcement Training Center (FLETC) public-supply wells (33H190 and 34H012). In addition, the BGJWSC Master Plan projects additional water demand in the North Mainland service area, which is planned to be met with the construction of a public-supply well near the Tradewinds/Altama developments located northwest of the Brunswick airport (Applied Technology \& Management, 2016). Scenario A simulates the new public-supply well using a pumping rate of $0.75 \mathrm{Mgal} / \mathrm{d}$.

The simulated results from Scenario A indicate minor water-level declines with groundwater-flow directions remaining nearly the same as the 2015 Base Case condition. For the Scenario A simulation, the potentiometric surface map of model layer 7 (UWBZ of UFA) indicates general groundwater-flow directions are from southwest to northeast in the southwestern part of the county and from south to north near Jekyll Island (fig. 16). Near the Brunswick peninsula, pumping in the Brunswick Cellulose and Pinova well fields creates a cone of depression with water levels below $15 \mathrm{ft}$, which is evident by the $5-\mathrm{ft}$ and $10-\mathrm{ft}$ contours surrounding the Brunswick Cellulose well field. The tight spacing of the waterlevel contours indicates steep horizontal-head gradients with groundwater-flow directions toward the center of pumping at Brunswick Cellulose.

The simulated water-level changes for Scenario A when compared to 2015 Base Case indicate a range from $+0.3 \mathrm{ft}$ to $-0.9 \mathrm{ft}$ with tight concentric contours indicating locations of wells where pumping has been modified. The location of the Brunswick Villa production well is the center near the $+0.3 \mathrm{ft}$ contour. For Scenario A, this simulated recovery was due to changes in pumping from the 2015 Base Case pumping rate of $0.947 \mathrm{Mgal} / \mathrm{d}$ to $0 \mathrm{Mgal} / \mathrm{d}$ (table 9). The planned construction of a BGJWSC public-supply well (TW) near the Tradewinds/Altama development is simulated in Scenario A, using a pumping rate of $0.75 \mathrm{Mgal} / \mathrm{d}$ (fig. 15). The simulated water-level change in model layer 7 (UWBZ of UFA) near the planned production well is $-0.9 \mathrm{ft}$. The -0.1 - $\mathrm{ft}$ water-level change contour extends from the southern tip of St. Simons Island westward over the Brunswick peninsula and remains outside the chloride plume area located near downtown Brunswick. In the chloride plume area, simulated waterlevel changes are minor, ranging from $+0.1 \mathrm{ft}$ (wells $33 \mathrm{H} 133$ and $34 \mathrm{H} 469$ ) to $-0.1 \mathrm{ft}$ (wells $34 \mathrm{H} 434,34 \mathrm{H} 125$, and 34H393; table 10). 

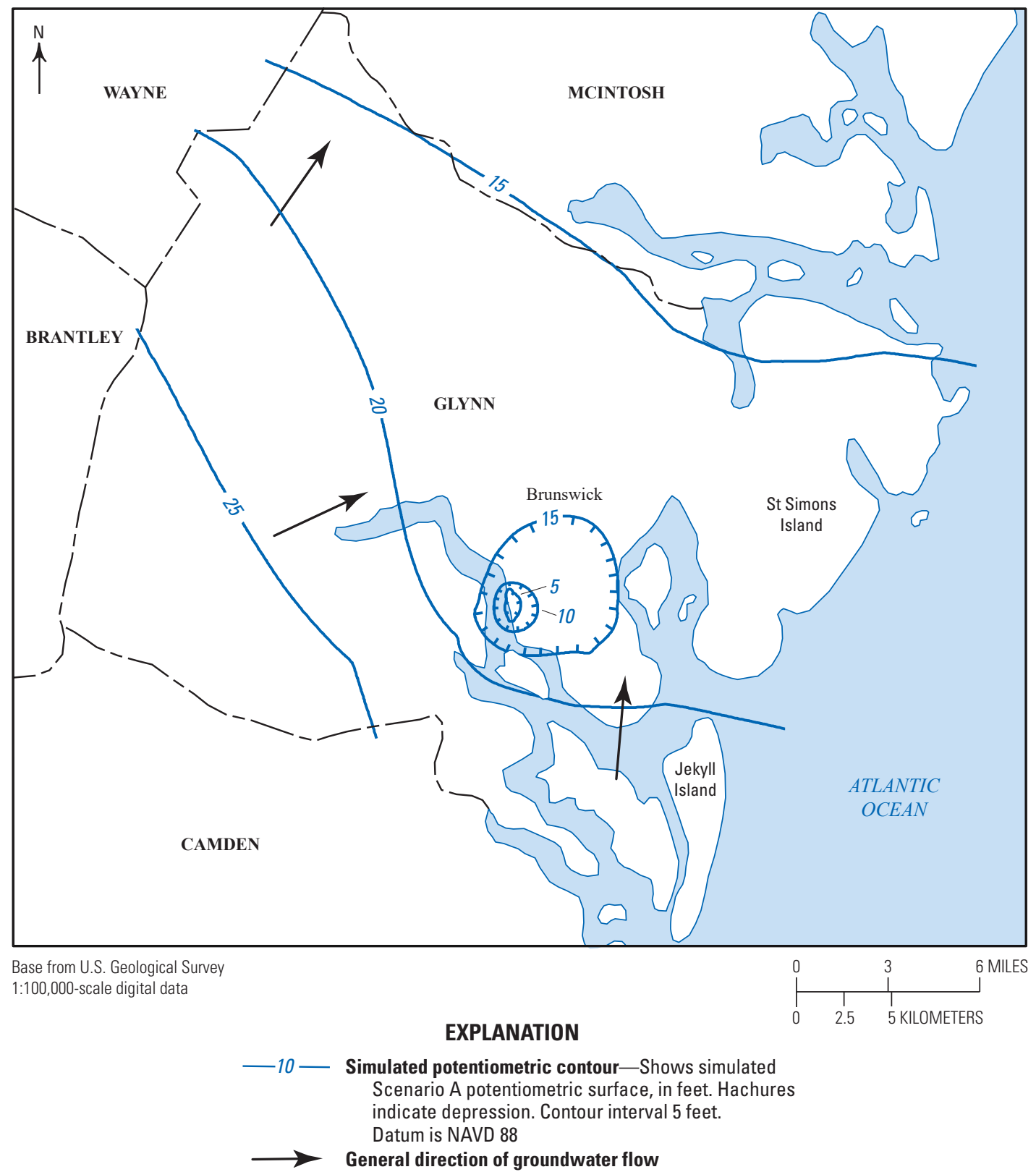

Figure 16. Map showing Scenario A simulated potentiometric surface for model layer 7, upper water-bearing zone of the Upper Floridan aquifer, Brunswick/Glynn County area of Georgia. 


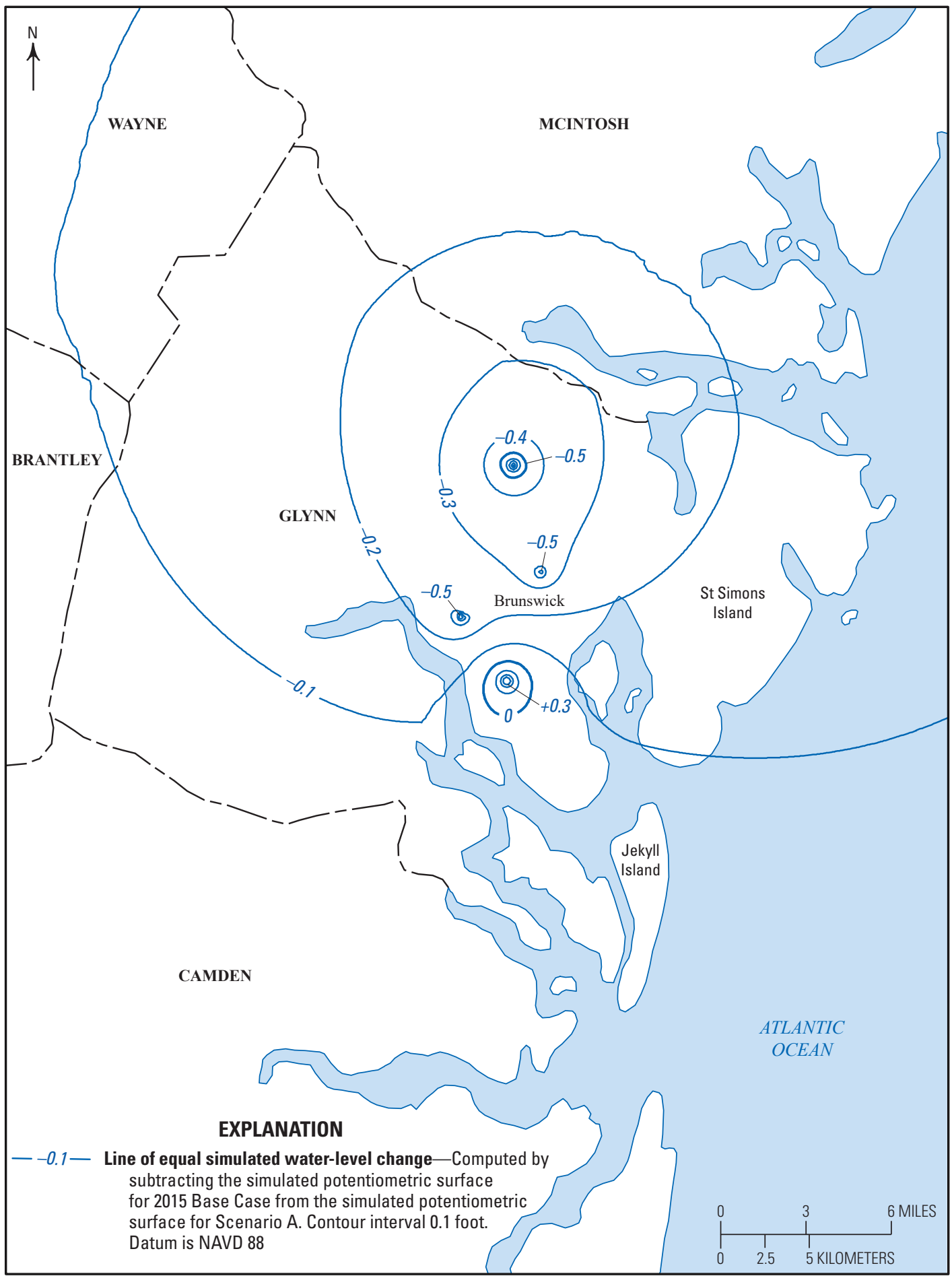

Base from U.S. Geological Survey 1:100,000-scale digital data

Figure 17. Map showing simulated water-level change from 2015 Base Case to Scenario A in model layer 7, upper water-bearing zone of the Upper Floridan aquifer, Brunswick/Glynn County area of Georgia. 


\section{Scenario B}

Scenario B represents the additional projected pumping required to meet the demand for public supply through the year 2035. The BGJWSC had consulting firms prepare a 5 -year update to the BGJWSC Water and Sewer Master Plan for the 20-year planning period 2015-35 (Applied Technology \& Management, 2016). The BGJWSC water and sewer systems incorporate four service areas: the North Mainland, the City of Brunswick, the South Mainland, and St. Simons Island. According to the Master Plan, the population in the four service areas is expected to increase from 61,684 in 2015 to 118,556 by the year 2035 , with the water demand for public supply increasing by $6.48 \mathrm{Mgal} / \mathrm{d}$. Currently (2015), the BGJWSC water distribution system has 11 production wells tapping the UFA and another 3 open to the Brunswick aquifer system (table 9). The North Mainland service area includes four water production facilities, with two wells tapping the Brunswick aquifer system and another two tapping the UWBZ of the UFA that have been used only in emergencies and are not included in table 9. According to the Master Plan, the water demand will increase $2.43 \mathrm{Mgal} / \mathrm{d}$ by the year 2035 due to expected growth in the North Mainland service area. This projected demand exceeds the permitted capacity, but the recently completed interconnection between the City of Brunswick and North Mainland service areas will likely extend the time needed to tap additional water sources (Applied Technology \& Management, 2016). In the North Mainland service area, the Scenario B simulation adds the proposed Tradewinds/Altama production well (TW) at a pumping rate of $0.75 \mathrm{Mgal} / \mathrm{d}$ (Scenario A) along with the proposed UFA production wells at Eastgate/Golden Isles (EGI) and Georgia Pacific (GP) each with an estimated pumping rate of $0.75 \mathrm{Mgal} / \mathrm{d}$ (fig. 15). Because the Brunswick aquifer system production wells in the North Mainland service area were pumping at rates near the sustainable yield of the aquifer during 2015, pumping was not increased for Scenario B. According to the Master Plan, the City of Brunswick service area will need an additional $1.76 \mathrm{Mgal} / \mathrm{d}$ from the UFA by the year 2035, with the increase in pumping for Scenario B distributed equally between the BGJWSC FLETC, I-95, Goodyear Park, and Howard Coffin Park public-supply wells (34H012, 33H190, 34H449, and 34H445; table 9). These same projections indicate an additional $0.71 \mathrm{Mgal} / \mathrm{d}$ will be needed from the UFA in the St. Simons Island service area, with the increase in pumping for Scenario B distributed between BGJWSC Hampton South and Harrington UFA production wells (35J010 and 35H080). The South Mainland service area has two active production wells tapping the UWBZ of the UFA and another well open to the Brunswick aquifer system with an estimated $1.58 \mathrm{Mgal} / \mathrm{d}$ of groundwater required by the year 2035. This additional demand will be met by increasing pumping rates at BGJWSC Brookman and Exit-29 Southport UFA production wells (32H049 and 33H344).

The simulated results from Scenario B indicate groundwater-flow directions shifting to a west to east component near new production wells in the BGJWSC North Mainland service area. For Scenario B, the potentiometric surface map (5-ft contours) of model layer 7, the UWBZ of the UFA, indicates general groundwater-flow directions from southwest to northeast in the western part of the county and from south to north near Jekyll Island (fig. 18). The shift in the 15-ft contour shows that a portion of groundwater flow is redirected toward the Brunswick peninsula and pumping centers located near downtown Brunswick. Near the Brunswick peninsula, movement of groundwater is from northeast to southwest toward a cone of depression in the Brunswick Cellulose well field, which is evident by the 5 - $\mathrm{ft}$ and $10-\mathrm{ft}$ contours. The tight spacing of these water-level contours indicates steep horizontal-head gradients and a substantial area of influence for active production wells.

The simulated water-level changes for Scenario B compared to 2015 Base Case indicate a range from $-0.6 \mathrm{ft}$ to $-1.8 \mathrm{ft}$ for model cells within Glynn County (fig. 19; table 10). The simulated increase in pumping is due to projected population growth to the year 2035 with the water demand for public supply increasing by $6.48 \mathrm{Mgal} / \mathrm{d}$. The concentric contours $(-1.0,-1.4,-1.6$, and $-1.8 \mathrm{ft})$ identify simulated production well locations and show local drawdown caused by increased pumping (fig. 19). The water-level change contours of $-1.8 \mathrm{ft}$ are located north of Brunswick where three publicsupply wells are proposed to meet future water demand. On St. Simons Island, combined simulated increases in pumping by BGJWSC at Hampton South (well 35J010) and Harrington (well $35 \mathrm{H} 080$ ) of $0.71 \mathrm{Mgal} / \mathrm{d}$ produce local simulated water-level changes of $-1.4 \mathrm{ft}$. The $-1.0 \mathrm{ft}$ water-level change contour extends offshore near St. Simons Island and covers the southern part of McIntosh County and western part of Glynn County. Near the chloride plume in downtown Brunswick, simulated increases in pumping at BGJWSC Goodyear Park and Howard Coffin Park wells (34H449 and 34H445) generate local simulated water-level changes of $-1.7 \mathrm{ft}$ (well 34H552; table 10). The simulated water-level change within the chloride plume area generally ranges between -1.0 and $-1.5 \mathrm{ft}$.

Simulated potentiometric gradients for Scenario B in the five potentiometric profiles $\left(A-A^{\prime}\right.$ to $\left.E-E^{\prime}\right)$ constructed in close proximity to the chloride plume show horizontal hydraulichead gradients similar to those of the 2015 Base Case simulation. A comparison of simulated heads for the 2015 Base Case and Scenario B along constructed profiles $A-A^{\prime}$ to $E-E^{\prime}$ show decreased heads as a result of higher pumping rates. The simulated head differences are calculated using the simulated heads at the endpoints for each of the profiles (table 10). For the Scenario B simulation, higher pumping rates yield simulated head differences that range between 7.60 and $9.59 \mathrm{ft}$. In profiles $A-A^{\prime}$ to $D-D^{\prime}$, simulated potentiometric gradients range between 6.6 and $9.7 \mathrm{ft} / \mathrm{mi}$ near the Brunswick Cellulose well field and $2.9 \mathrm{ft} / \mathrm{mi}$ in profile $E-E^{\prime}$, oriented in a general south to north direction. The higher pumping rates for Scenario B, in general, reduce simulated heads with potentiometric gradients remaining similar to the 2015 Base Case because of changes in pumping occurring away from the downtown Brunswick area. 


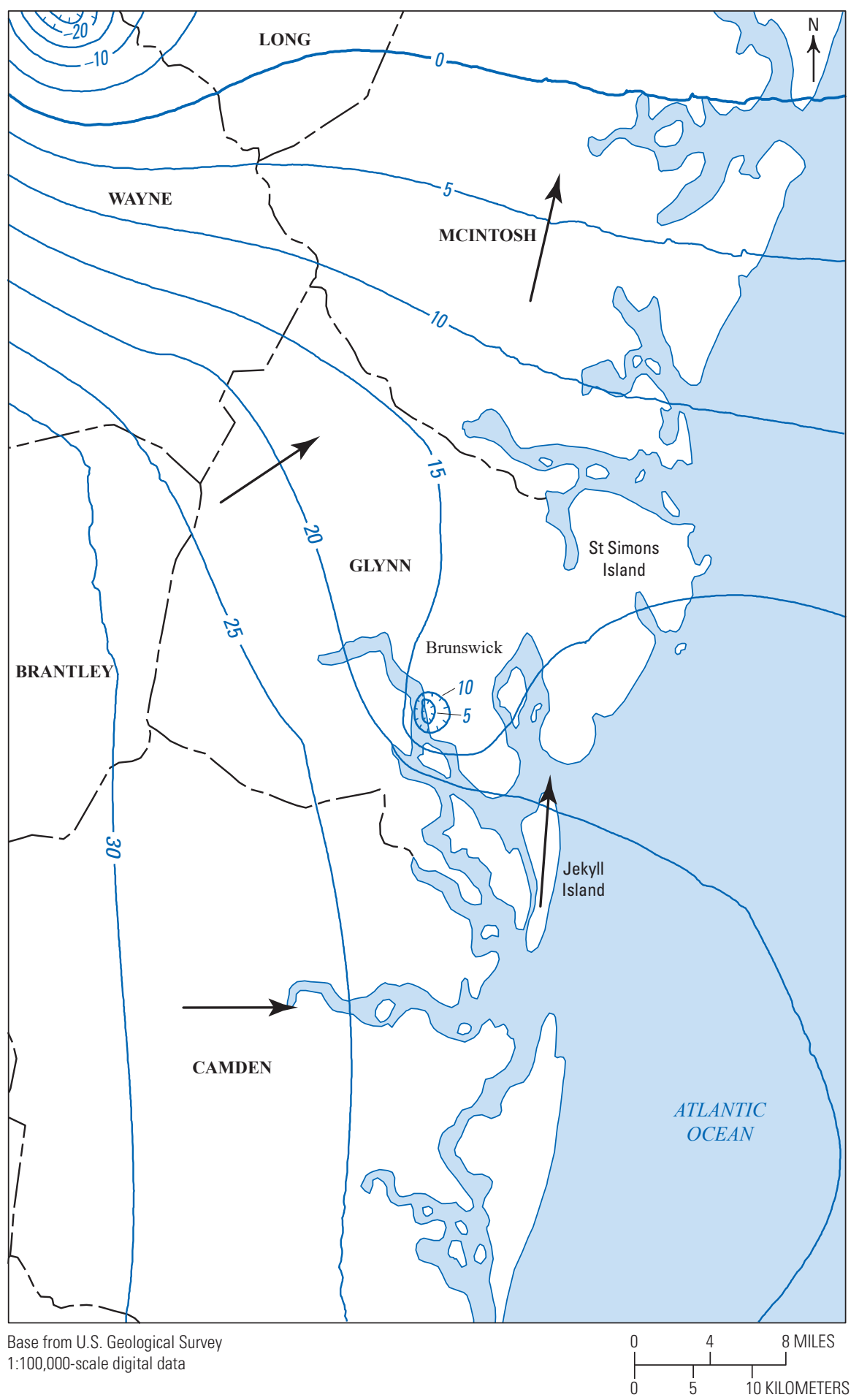

EXPLANATION

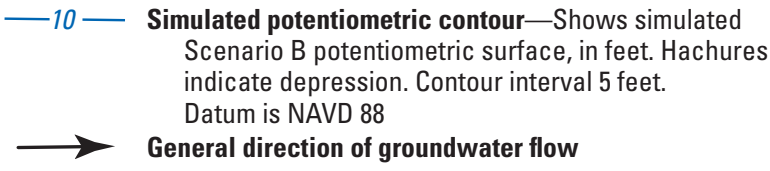

Figure 18. Map showing Scenario B simulated potentiometric surface for model layer 7, upper water-bearing zone of the Upper Floridan aquifer, Brunswick/Glynn County area of Georgia. 


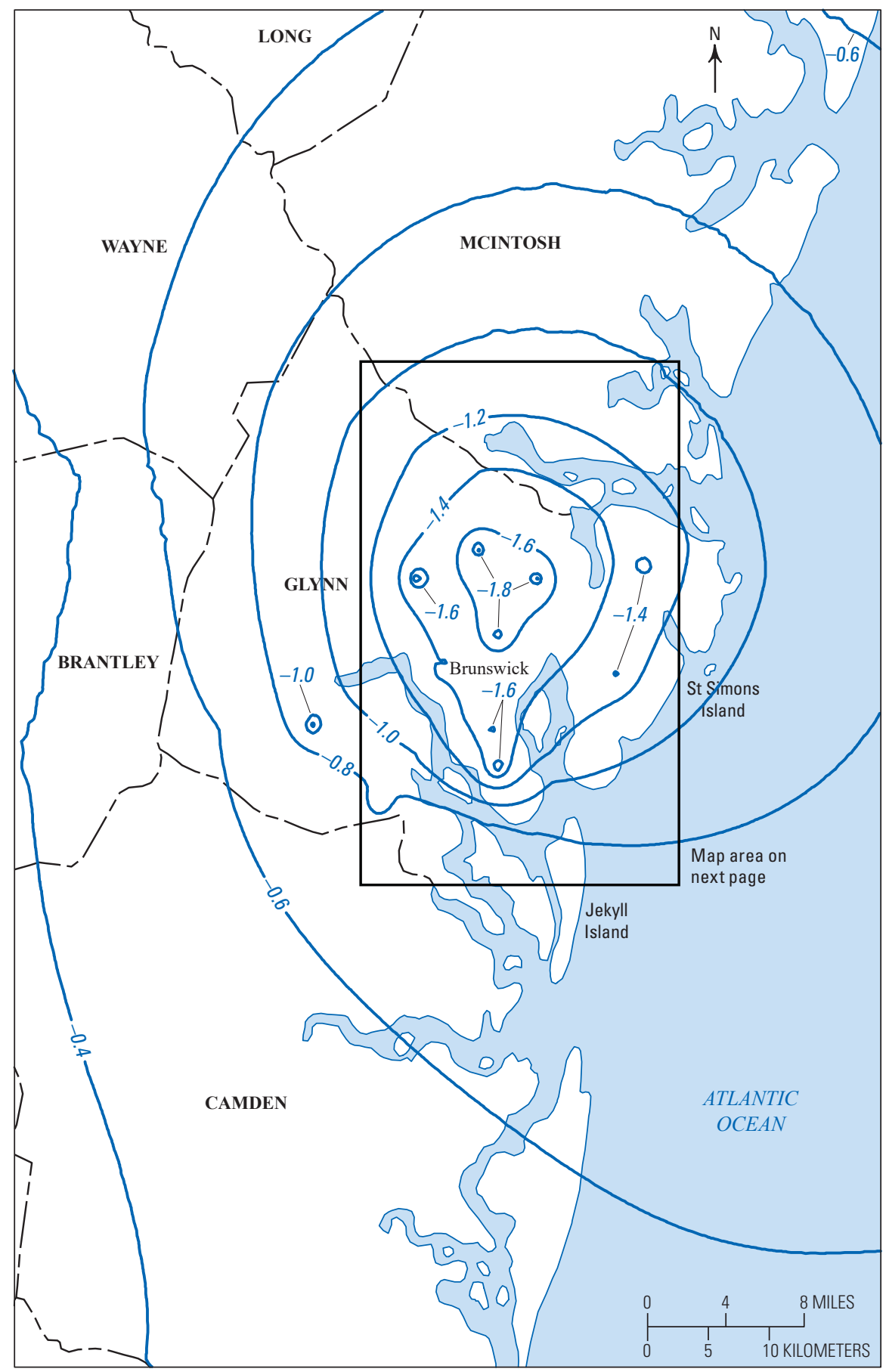

Base from U.S. Geological Survey

1:100,000-scale digital data

\section{EXPLANATION}

- -0.4 - Line of equal simulated water-level change - Computed by subtracting the simulated potentiometric surface for 2015 Base Case from the simulated potentiometric surface for Scenario B. Contour interval 0.2 foot. Datum is NAVD 88

Figure 19. Maps showing simulated water-level change from 2015 Base Case to Scenario B in model layer 7, upper water-bearing zone of the Upper Floridan aquifer, Brunswick/Glynn County area of Georgia. 


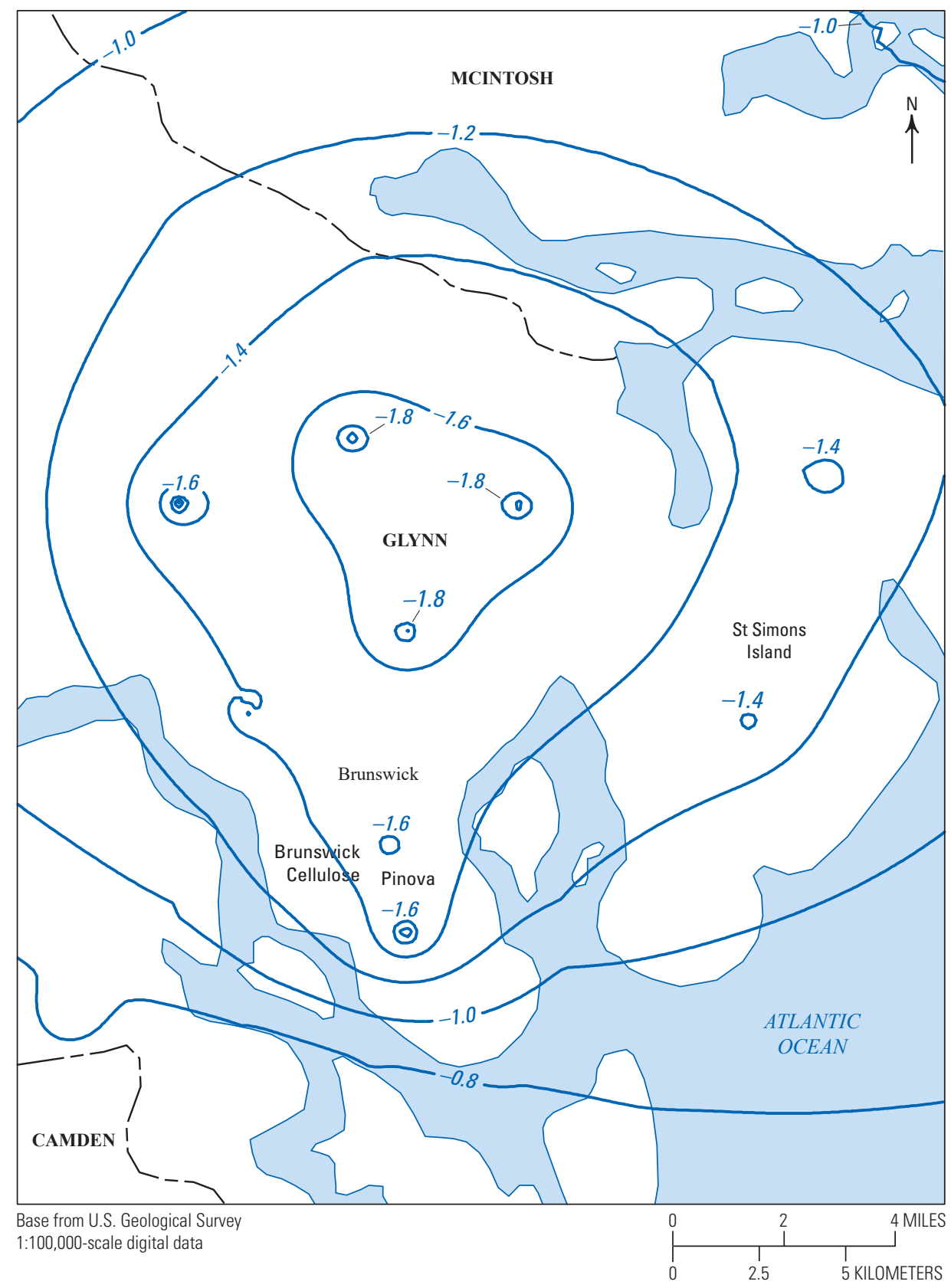

\section{EXPLANATION}

$-1.4-$ Line of equal simulated water-level change - Computed by subtracting the simulated potentiometric surface for 2015 Base Case from the simulated potentiometric surface for Scenario B. Contour interval 0.2 foot. Datum is NAVD 88

Figure 19. - Continued 


\section{Scenario C}

Scenario $\mathrm{C}$ represents the elimination of pumping at Brunswick Cellulose and Pinova located in northern Brunswick within or adjacent to the chloride plume area. This scenario highlights the hypothetical case of economic conditions that would lead to plant closures at Brunswick Cellulose and Pinova. Ceasing operations at these facilities would require the deactivation of nine production wells that produced $31.3 \mathrm{Mgal} / \mathrm{d}$ during October 2015 (table 9). A similar case was documented in Camden County, Ga., during October 2000, when the Durango Paper Company shut down the facility, resulting in a decrease of about $36 \mathrm{Mgal} / \mathrm{d}$ in groundwater pumpage from the Upper and Lower Floridan aquifers (Peck and others, 2005). This plant closure was simulated in one of the scenarios, documented in Payne and others (2005), in which water-level rises in the UFA ranged from 2 to $4 \mathrm{ft}$ in the Glynn County area. The simulated potentiometric contour map for 2015 Base Case indicates the groundwater pumping from seven production wells (27.9 Mgal/d; table 9) located at Brunswick Cellulose created the main cone of depression with water levels below $0 \mathrm{ft}$ surrounding active wells. The two production wells (3.41 Mgal/d; table 9) at Pinova Inc. are located east of the main cone of depression with simulated water levels just below $5 \mathrm{ft}$. For Scenario C, all other production wells remained active and were simulated at 2015 (Base Case) pumping rates.

The simulated results from Scenario C indicate major changes in the groundwater-flow directions near the city of Brunswick. The elimination of $31.3 \mathrm{Mgal} / \mathrm{d}$ pumping in the Brunswick area alters the groundwater-flow direction toward Brunswick from the north and east and shifts flow paths toward directions dominated by flow from the southwest toward the northeast (fig. 20). The 2015 Base Case simulation shows the 5- and 10-ft contours surrounding Brunswick Cellulose, which is an indication of the cone of depression caused by pumping at seven production wells at the facility. Irregular patterns in the 23.5- and 24-ft contours indicate the influence of active production wells on local groundwaterflow directions. Simulated heads in the downtown Brunswick area rebound as shown by the 25 -ft contour for Scenario C and influence the shape and extent of a secondary cone of depression located in parts of Wayne and Long Counties (fig. 20). This secondary cone of depression is centered near the Jesup facility, which pumped an estimated $57.8 \mathrm{Mgal} / \mathrm{d}$ from the UFA during 2010 (Lawrence, 2015). In Scenario $\mathrm{C}$, the horizontal hydraulic-head gradient in the UWBZ of the UFA across the Brunswick peninsula ranges from 0.6 to $1.0 \mathrm{ft} / \mathrm{mile}$ with groundwater-flow directions from the southwest toward the northeast.

The simulated water-level changes for Scenario C compared to 2015 Base Case indicate a range from $3 \mathrm{ft}$ to greater than $25 \mathrm{ft}$ within Glynn County. The simulated water-level changes represent the expected water-level rise if Brunswick Cellulose and Pinova were to close and $31.3 \mathrm{Mgal} / \mathrm{d}$ of pumping was eliminated from nine production wells. The 2-ft water-level change contour extends across Camden, Brantley, Wayne, and Long Counties (fig. 21). On the basis of simulation results, a water-level rise of $3 \mathrm{ft}$ could be expected in parts of Camden, Glynn, Wayne, and McIntosh Counties. The maximum simulated water-level change of greater than $25 \mathrm{ft}$ encompasses a small area within the Brunswick Cellulose well field. Inside the chloride plume in downtown Brunswick, simulated water-level changes generally range between 8 and $15 \mathrm{ft}$ and are greater than $20 \mathrm{ft}$ near the Brunswick Cellulose well field (table 10). Pumping from the Pinova well field influences the shape of the $10-\mathrm{ft}$ contour, which has shifted east to include the facility.

Simulated potentiometric gradients for Scenario $\mathrm{C}$ in the five potentiometric profiles $\left(A-A^{\prime}\right.$ to $\left.E-E^{\prime}\right)$ constructed in close proximity to the chloride plume show horizontal hydraulic gradients changing due to elimination of pumping at the industrial facilities. Profiles $A-A^{\prime}, C-C^{\prime}$, and $D-D^{\prime}$ indicate groundwater-flow directions have reversed and now flow is in a northwest, east, and southeast direction away from the Brunswick Cellulose well field (fig. 22). The simulated heads for Scenario $\mathrm{C}$ along the constructed profiles $A-A^{\prime}$ to $E-E^{\prime}$ show significantly higher heads as a result of lower pumping rates. The simulated head differences are calculated using the simulated heads at the endpoints for each of the profiles (table 11). The lower pumping rates for the Scenario C simulation reduce simulated head differences, which range from 0.6 to $1.2 \mathrm{ft}$. The result is simulated potentiometric gradients that range between 0.4 and $0.9 \mathrm{ft} / \mathrm{mi}$ in profiles $A-A^{\prime}$ to $D-D^{\prime}$ located nearest the industrial well field and $0.4 \mathrm{ft} / \mathrm{mi}$ in profile $E$ oriented in a general south to north direction. The hydraulic-head gradients in profiles $B-B^{\prime}$ and $E-E^{\prime}$ are reduced to 0.7 and $0.4 \mathrm{ft} / \mathrm{mi}$, respectively, but the general groundwaterflow direction remains from the south toward the north. 


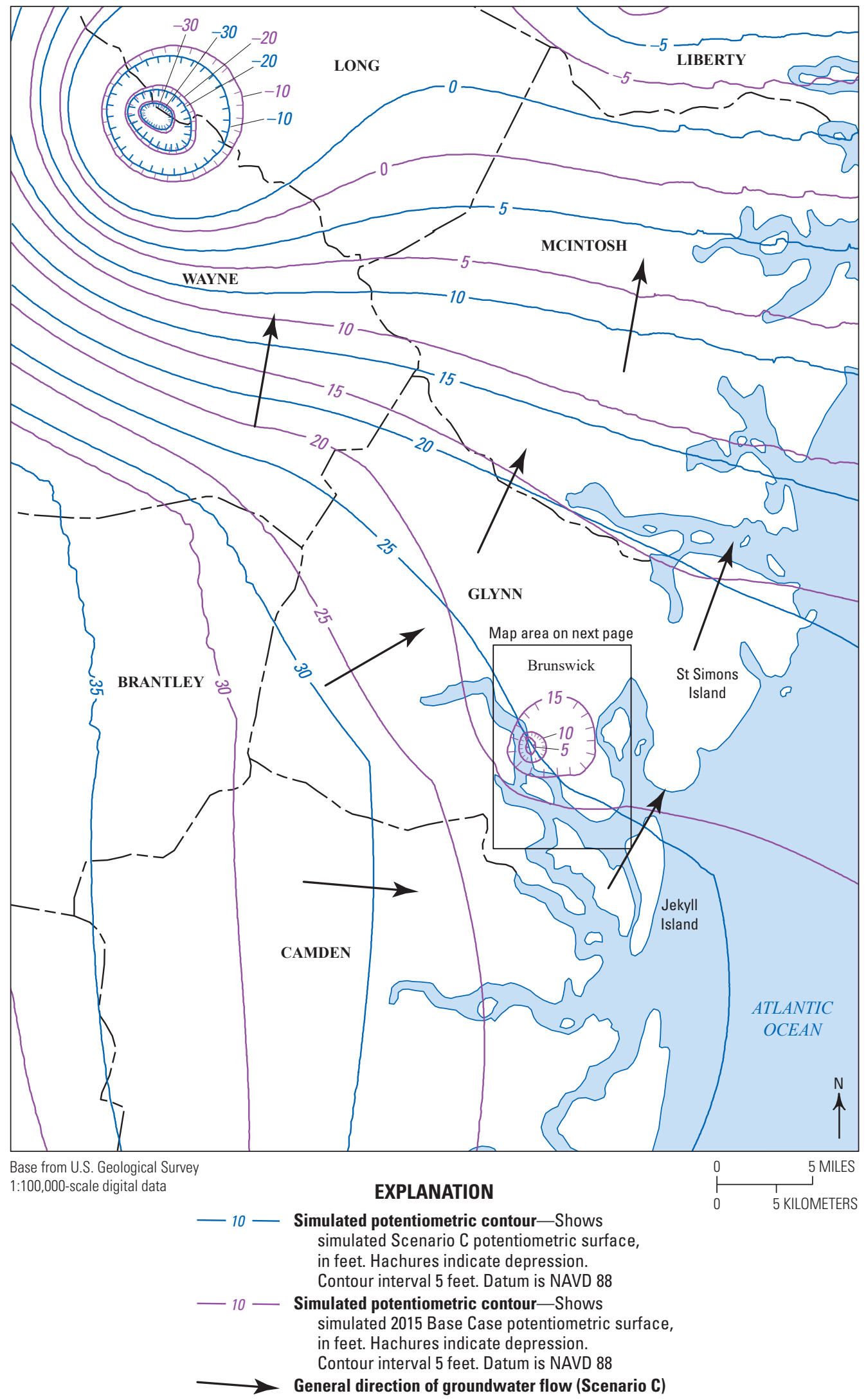

Figure 20. Maps showing simulated 2015 Base Case and Scenario C potentiometric surface for model layer 7, upper water-bearing zone of the Upper Floridan aquifer, Brunswick/Glynn County area of Georgia. 


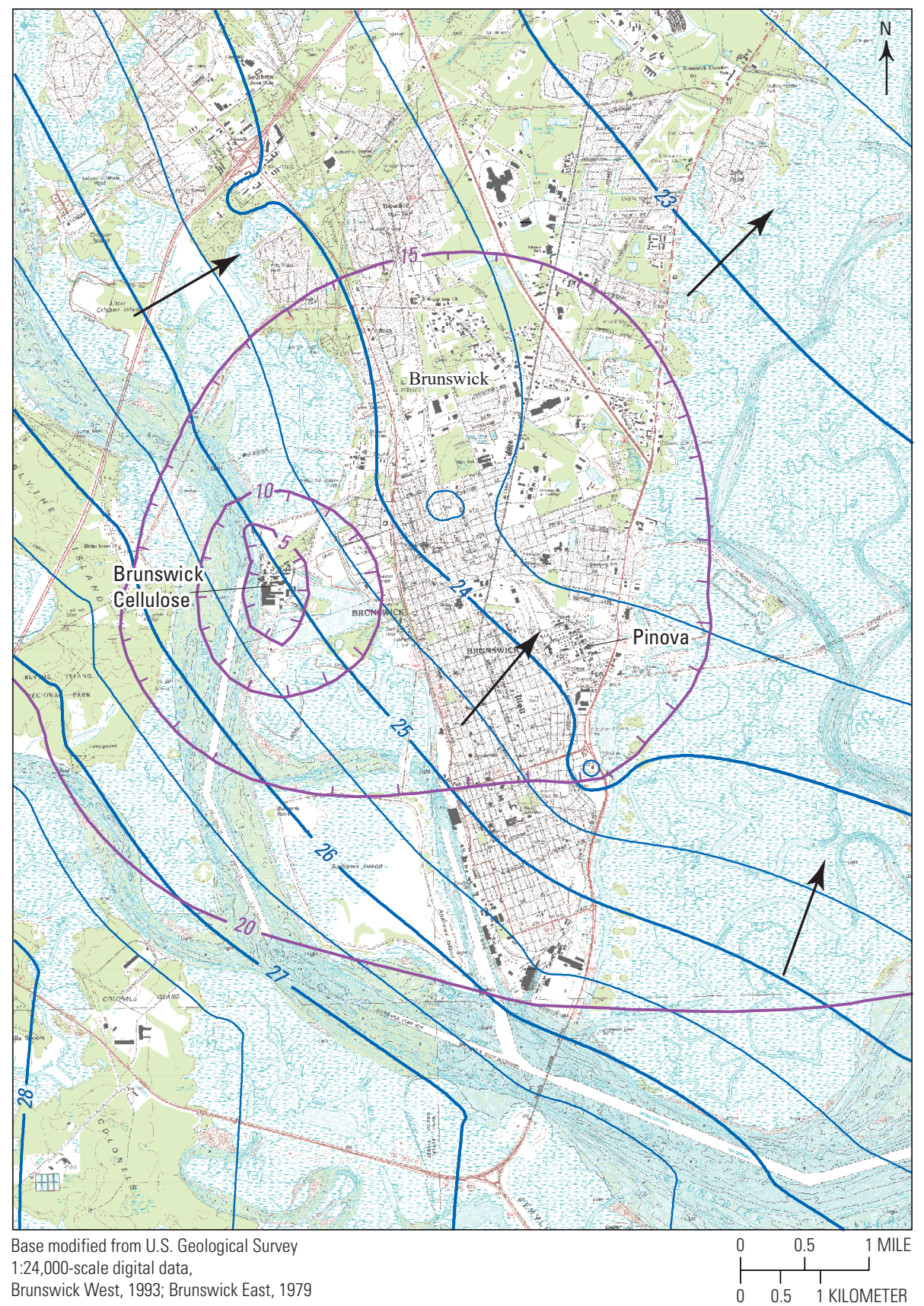

EXPLANATION

- 25 - Simulated potentiometric contour-Shows

simulated Scenario C potentiometric surface,

in feet. Contour interval 0.5 foot.

Datum is NAVD 88

- 10 - Simulated potentiometric contour-Shows

simulated 2015 Base Case potentiometric surface,

in feet. Hachures indicate depression.

Contour interval 5 feet. Datum is NAVD 88

General direction of groundwater flow (Scenario C)

Figure 20. - Continued 


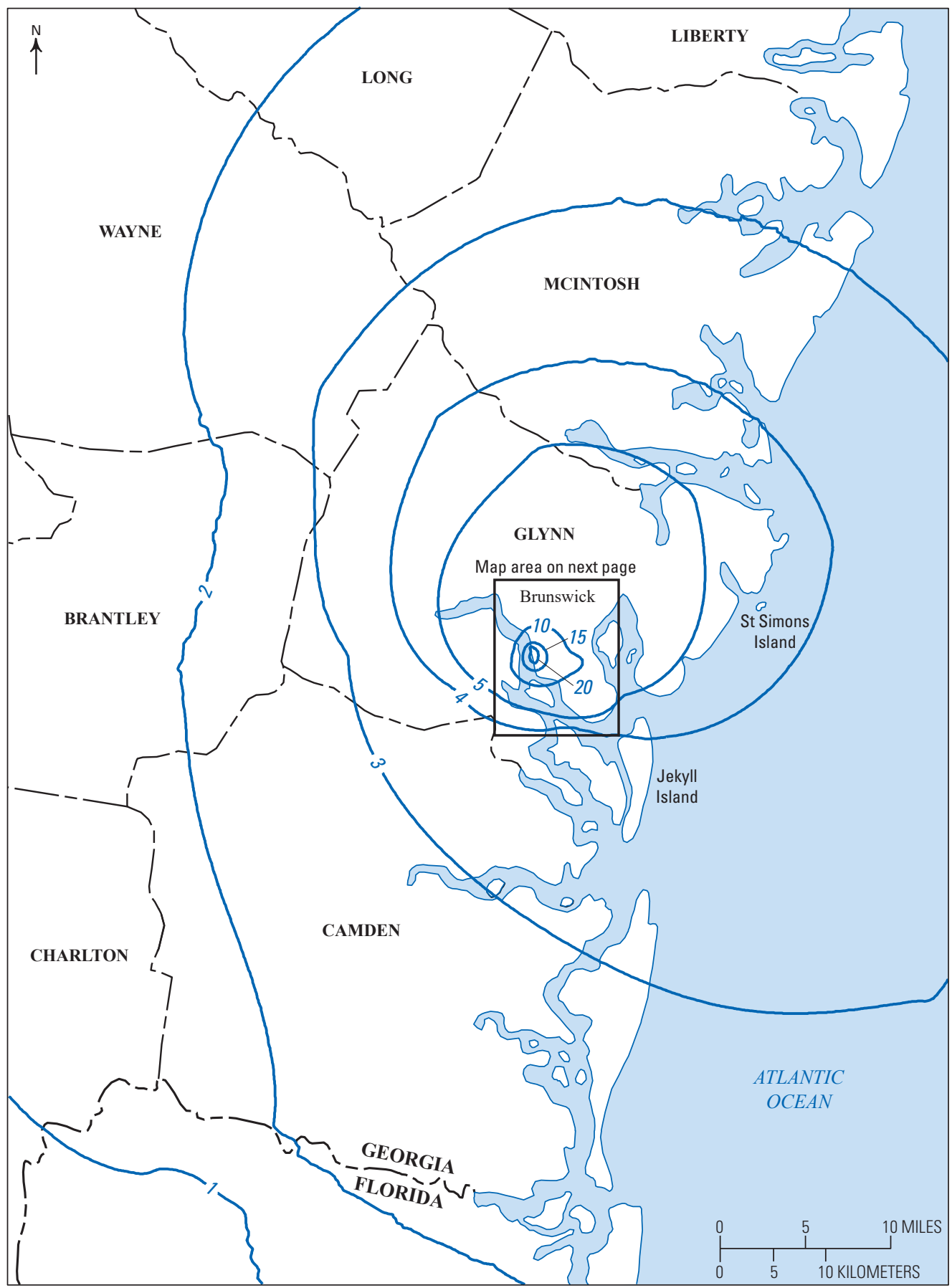

Base from U.S. Geological Survey 1:100,000-scale digital data

\section{EXPLANATION}

$-1-$ Line of equal simulated water-level change-Computed by subtracting the simulated potentiometric surface for 2015 Base Case from the simulated potentiometric surface for Scenario C. Contour interval, in feet, is variable. Datum is NAVD 88

Figure 21. Maps showing simulated water-level change from 2015 Base Case to Scenario C in model layer 7, upper water-bearing zone of the Upper Floridan aquifer, Brunswick/Glynn County area of Georgia. 


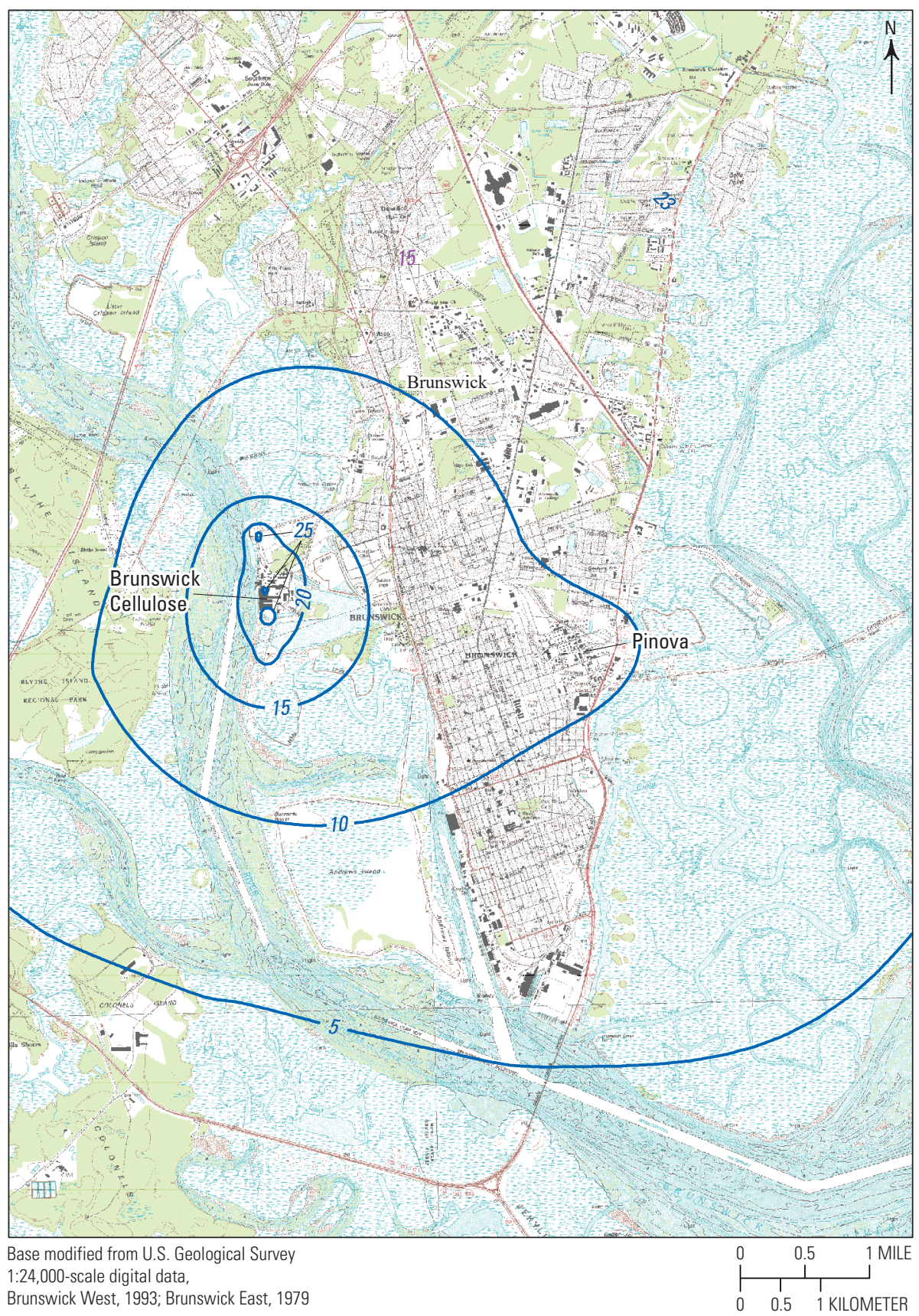

EXPLANATION

- 5 - Line of equal simulated water-level change - Computed by subtracting the simulated potentiometric surface for 2015 Base Case from the simulated potentiometric surface for Scenario C. Contour interval, in feet, is variable. Datum is NAVD 88

Figure 21. - Continued 
Table 10. Simulated groundwater levels for 2015 Base Case, Scenarios A, B, C, and D1-D3 at selected wells for model layer 7, upper water-bearing zone of the Upper Floridan aquifer, Brunswick/Glynn County area of Georgia.

[Simulated groundwater levels are feet above NAVD 88; see fig. 1-1 for well locations]

\begin{tabular}{|c|c|c|c|c|c|c|c|}
\hline \multirow{3}{*}{$\begin{array}{c}\text { Well } \\
\text { identifier }\end{array}$} & \multicolumn{7}{|c|}{ Simulated groundwater levels, in feet } \\
\hline & \multirow{2}{*}{$\begin{array}{c}2015 \\
\text { Base Case }\end{array}$} & \multirow[b]{2}{*}{ Scenario A } & \multirow[b]{2}{*}{ Scenario B } & \multirow{2}{*}{$\begin{array}{c}\text { Scenario C } \\
\text { O percent }\end{array}$} & \multicolumn{3}{|c|}{ Scenario D } \\
\hline & & & & & $\begin{array}{c}\text { D1 } \\
\text { (12.5 percent) }\end{array}$ & $\begin{array}{c}\text { D2 } \\
\text { (25 percent) }\end{array}$ & $\begin{array}{c}\text { D3 } \\
\text { (50 percent) }\end{array}$ \\
\hline $33 \mathrm{G} 002$ & 23.70 & 23.70 & 23.00 & 27.80 & 27.30 & 26.80 & 25.80 \\
\hline $33 \mathrm{G} 008$ & 23.60 & 23.50 & 22.80 & 27.60 & 27.10 & 26.60 & 25.60 \\
\hline $33 \mathrm{G} 024$ & 25.40 & 25.30 & 24.60 & 29.00 & 28.60 & 28.10 & 27.20 \\
\hline $33 \mathrm{H} 120$ & 10.30 & 10.30 & 8.91 & 24.30 & 22.50 & 20.70 & 17.20 \\
\hline $33 \mathrm{H} 130$ & 9.13 & 9.15 & 7.79 & 24.50 & 22.60 & 20.60 & 16.80 \\
\hline $33 \mathrm{H} 133$ & 10.50 & 10.60 & 9.21 & 24.50 & 22.70 & 21.00 & 17.50 \\
\hline $33 \mathrm{H} 177$ & 25.10 & 25.00 & 24.30 & 28.90 & 28.40 & 27.90 & 27.00 \\
\hline $33 \mathrm{H} 180$ & 13.00 & 13.10 & 11.60 & 23.70 & 22.40 & 21.00 & 18.30 \\
\hline $33 \mathrm{H} 193$ & 22.10 & 22.00 & 21.10 & 27.00 & 26.40 & 25.80 & 24.50 \\
\hline $33 \mathrm{H} 207$ & 12.00 & 12.00 & 10.90 & 25.80 & 24.00 & 22.30 & 18.80 \\
\hline $33 \mathrm{H} 211$ & 2.58 & 2.53 & 1.31 & 25.00 & 22.20 & 19.40 & 13.70 \\
\hline $33 \mathrm{H} 213$ & 5.23 & 5.20 & 3.97 & 25.00 & 22.50 & 20.00 & 15.00 \\
\hline 34G002 & 20.00 & 19.90 & 19.00 & 25.70 & 25.00 & 24.30 & 22.80 \\
\hline $34 \mathrm{G} 003$ & 23.00 & 22.90 & 22.20 & 26.90 & 26.40 & 25.90 & 24.90 \\
\hline 34G009 & 22.50 & 22.40 & 21.80 & 25.90 & 25.50 & 25.00 & 24.20 \\
\hline $34 \mathrm{G} 016$ & 20.80 & 20.80 & 20.00 & 24.90 & 24.40 & 23.90 & 22.80 \\
\hline 34G017 & 20.30 & 20.20 & 19.50 & 24.70 & 24.20 & 23.60 & 22.50 \\
\hline $34 \mathrm{G} 020$ & 21.90 & 21.80 & 21.20 & 25.60 & 25.20 & 24.70 & 23.70 \\
\hline $34 \mathrm{H} 062$ & 13.10 & 13.10 & 11.60 & 23.60 & 22.30 & 20.90 & 18.30 \\
\hline 34H095 & 19.60 & 19.50 & 18.60 & 25.60 & 24.90 & 24.10 & 22.60 \\
\hline $34 \mathrm{H} 112$ & 15.80 & 15.80 & 14.60 & 25.10 & 23.90 & 22.70 & 20.40 \\
\hline 34H117 & 15.20 & 15.20 & 14.00 & 25.10 & 23.80 & 22.60 & 20.10 \\
\hline $34 \mathrm{H} 125$ & 14.60 & 14.50 & 13.20 & 24.60 & 23.40 & 22.10 & 19.60 \\
\hline $34 \mathrm{H} 128$ & 13.90 & 13.90 & 12.60 & 24.60 & 23.20 & 21.90 & 19.20 \\
\hline $34 \mathrm{H} 344$ & 13.20 & 13.20 & 11.70 & 23.90 & 22.60 & 21.20 & 18.50 \\
\hline $34 \mathrm{H} 355$ & 13.40 & 13.40 & 12.10 & 24.70 & 23.30 & 21.90 & 19.00 \\
\hline $34 \mathrm{H} 371$ & 17.20 & 17.20 & 16.10 & 25.30 & 24.30 & 23.30 & 21.30 \\
\hline $34 \mathrm{H} 373$ & 13.10 & 13.10 & 11.70 & 24.30 & 22.90 & 21.50 & 18.60 \\
\hline $34 \mathrm{H} 374$ & 11.90 & 11.90 & 10.50 & 24.40 & 22.90 & 21.30 & 18.10 \\
\hline $34 \mathrm{H} 393$ & 16.80 & 16.70 & 15.60 & 25.30 & 24.20 & 23.10 & 21.00 \\
\hline $34 \mathrm{H} 400$ & 12.90 & 12.90 & 11.60 & 24.50 & 23.10 & 21.60 & 18.70 \\
\hline $34 \mathrm{H} 401$ & 12.40 & 12.40 & 11.00 & 24.50 & 23.00 & 21.40 & 18.40 \\
\hline $34 \mathrm{H} 424$ & 12.60 & 12.60 & 11.10 & 23.90 & 22.50 & 21.10 & 18.20 \\
\hline $34 \mathrm{H} 434$ & 14.30 & 14.20 & 12.90 & 24.70 & 23.40 & 22.10 & 19.40 \\
\hline $34 \mathrm{H} 469$ & 11.90 & 12.00 & 10.50 & 24.00 & 22.50 & 21.00 & 17.90 \\
\hline 34H514 & 13.60 & 13.60 & 12.20 & 24.20 & 22.80 & 21.50 & 18.90 \\
\hline $34 \mathrm{H} 552$ & 13.30 & 13.30 & 11.60 & 23.20 & 22.00 & 20.70 & 18.20 \\
\hline
\end{tabular}




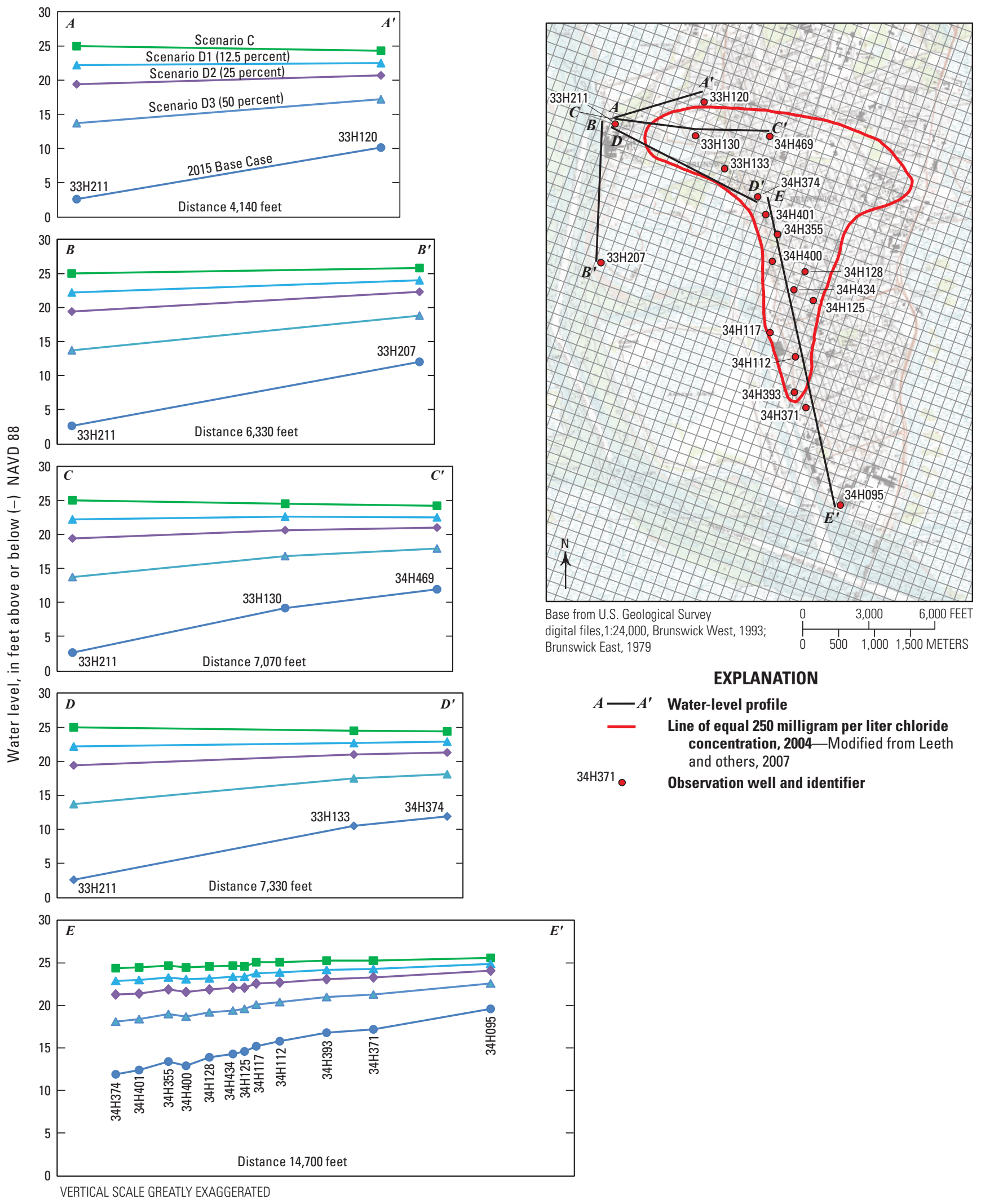

Figure 22. Graphs showing simulated potentiometric profiles near the chloride plume in the Upper Florida aquifer near downtown Brunswick, Georgia, for 2015 Base Case and Scenarios C and D. 
Table 11. Simulated head difference and horizontal potentiometric gradients for 2015 Base Case and Scenarios A, B, C, D1, D2, and D3 along profiles $A-A^{\prime}, B-B^{\prime}, C-C^{\prime}, D-D^{\prime}$, and $E-E^{\prime}$ in the upper water-bearing zone of the Upper Floridan aquifer (model layer 7 ) in the downtown Brunswick area of Georgia.

[Horizontal hydraulic-head gradients calculated using simulated heads at the endpoints of profile; values in bold indicate groundwater-flow direction has reversed from 2015 Base Case simulation; Scenario C (0 percent); Scenario D1 (12.5 percent); Scenario D2 (25 percent); Scenario D3 (50 percent); see figures 13 and 22 for location of profiles]

\begin{tabular}{|c|c|c|c|c|c|c|c|c|c|c|c|c|c|c|c|c|}
\hline \multirow{3}{*}{ Profile } & \multirow{3}{*}{$\begin{array}{c}\text { Number } \\
\text { of } \\
\text { wells }\end{array}$} & \multirow{3}{*}{$\begin{array}{l}\text { Distance, } \\
\text { in miles }\end{array}$} & \multicolumn{7}{|c|}{$\begin{array}{l}\text { Simulated head difference, } \\
\text { in feet }\end{array}$} & \multicolumn{7}{|c|}{$\begin{array}{c}\text { Simulated potentiometric gradient, } \\
\text { in feet per mile }\end{array}$} \\
\hline & & & \multirow{2}{*}{$\begin{array}{l}2015 \\
\text { Base } \\
\text { Case }\end{array}$} & \multicolumn{6}{|c|}{ Scenario } & \multirow{2}{*}{$\begin{array}{l}2015 \\
\text { Base } \\
\text { Case }\end{array}$} & \multicolumn{6}{|c|}{ Scenario } \\
\hline & & & & A & B & C & D1 & D2 & D3 & & A & B & C & D1 & D2 & D3 \\
\hline$A-A^{\prime}$ & 2 & 0.78 & 7.72 & 7.77 & 7.60 & 0.70 & 0.30 & 1.30 & 3.50 & 9.8 & 9.9 & 9.7 & 0.9 & 0.4 & 1.7 & 4.5 \\
\hline$B-B^{\prime}$ & 2 & 1.20 & 9.42 & 9.47 & 9.59 & 0.80 & 1.80 & 2.90 & 5.10 & 7.9 & 7.9 & 8.0 & 0.7 & 1.5 & 2.4 & 4.3 \\
\hline$C-C^{\prime}$ & 3 & 1.34 & 9.32 & 9.47 & 9.19 & 1.00 & 0.30 & 1.60 & 4.20 & 7.0 & 7.1 & 6.9 & 0.7 & 0.2 & 1.2 & 3.1 \\
\hline$D-D^{\prime}$ & 3 & 1.39 & 9.32 & 9.37 & 9.19 & 0.60 & 0.70 & 1.90 & 4.40 & 6.7 & 6.7 & 6.6 & 0.4 & 0.5 & 1.4 & 3.2 \\
\hline$E-E^{\prime}$ & 12 & 2.78 & 7.70 & 7.60 & 8.10 & 1.20 & 2.00 & 2.80 & 4.50 & 2.8 & 2.7 & 2.9 & 0.4 & 0.7 & 1.0 & 1.6 \\
\hline
\end{tabular}

\section{Scenario D}

Scenario D represents changing pumping rates at the industrial facilities in northern Brunswick to determine pumping rates required to reverse the horizontal hydraulichead gradients. Prior to groundwater development, flow directions were toward the coast in a general west to east direction (Krause and Randolph, 1989). The combined Brunswick Cellulose and Pinova facilities had nine active production wells during 2015, with a pumping rate of $31.3 \mathrm{Mgal} / \mathrm{d}$. The previous scenario (Scenario C) represents plant closures and the elimination of pumping at these nine active production wells, whereas Scenario D decreases pumping at these wells to $12.5,25$, and 50 percent of the 2015 Base Case simulation pumping rates (designated Scenarios D1, D2, and D3, respectively). These conditions represent scaledback operations at the facilities or less groundwater from the Floridan aquifer system needed for cooling. The changes in simulated pumping rates were applied equally among the nine active industrial production wells, and the results were compared to the 2015 Base Case simulation to determine local head gradients and groundwater-flow directions.

The simulated results from Scenario D indicate that small changes in pumping rates at Brunswick Cellulose alter the natural groundwater-flow direction from southwest to northeast.

For Scenario C, the horizontal hydraulic-head gradient in the UWBZ of the UFA across the Brunswick peninsula ranges from 0.4 to $0.9 \mathrm{ft} / \mathrm{mile}$, with groundwater-flow directions toward the northeast (fig. 23A). The potentiometric surface map for Scenario $\mathrm{C}$ indicates flatter horizontal hydraulichead gradients $(0.4 \mathrm{ft} / \mathrm{mi})$ near downtown Brunswick. These gradients are influenced by three active production wells for public supply. The closed contours and the shift in the 23.5-ft contour indicate the general locations of these wells with groundwater-flow directions toward the northeast. For 12.5 percent (Scenario D1) of industrial pumping, general groundwater-flow directions are maintained with minor cones of depressions caused by active productions wells (fig. 23B). The closed 22- and 22.5-ft contours near downtown Brunswick highlight the locations of active production wells. Additional pumping deepens the cone of depression and increases the horizontal hydraulic-head gradients, which range between 1.2 and $1.8 \mathrm{ft} / \mathrm{mi}$, to the south and southwest of Brunswick, with more gentle head gradients of approximately $0.4 \mathrm{ft} / \mathrm{mi}$ extending to the northeast. For 25 percent (Scenario D2) of industrial pumping, the cone of depression is more pronounced, with steeper horizontal hydraulic-head gradients upgradient of Brunswick Cellulose (fig. 23C). In addition, some groundwater flow from the north and northeast is redirected to the south and southwest toward the Brunswick Cellulose well field. The horizontal hydraulic-head gradients range from $1.7 \mathrm{ft} / \mathrm{mi}$ to $2.4 \mathrm{ft} / \mathrm{mi}$, with groundwaterflow directions from the southwest to northeast (fig. $23 C$; table 11). The shape of the contours indicate groundwater-flow directions shift to a northwesterly direction toward the center of industrial pumping. A small component of groundwater flow is east to west across the northern part of the chloride plume. Horizontal hydraulic-head gradients are relatively flat in the northern part of Brunswick, with groundwaterflow directions influenced by active production wells. For 50 percent (Scenario D3) of industrial pumping, the cone of depression is deep enough to capture groundwater flow in the northeastern portion of the map and redirect flow toward the pumping center (fig. 23D). The groundwater-flow component from the southwest toward the Brunswick Cellulose well field yields horizontal hydraulic-head gradients of $4.5 \mathrm{ft} / \mathrm{mi}$ within the UWBZ of the UFA (model layer 7). The horizontal hydraulic-head component from groundwater flowing from east to west toward the cone of depression approaches $4 \mathrm{ft} / \mathrm{mi}$. The component of groundwater flow from the northeast toward the pumping center in the southwest is about $2.2 \mathrm{ft} / \mathrm{mi}$. The pumping at the Pinova facility produces a secondary cone of depression evident by the 18 -ft contour surrounding the facility. 


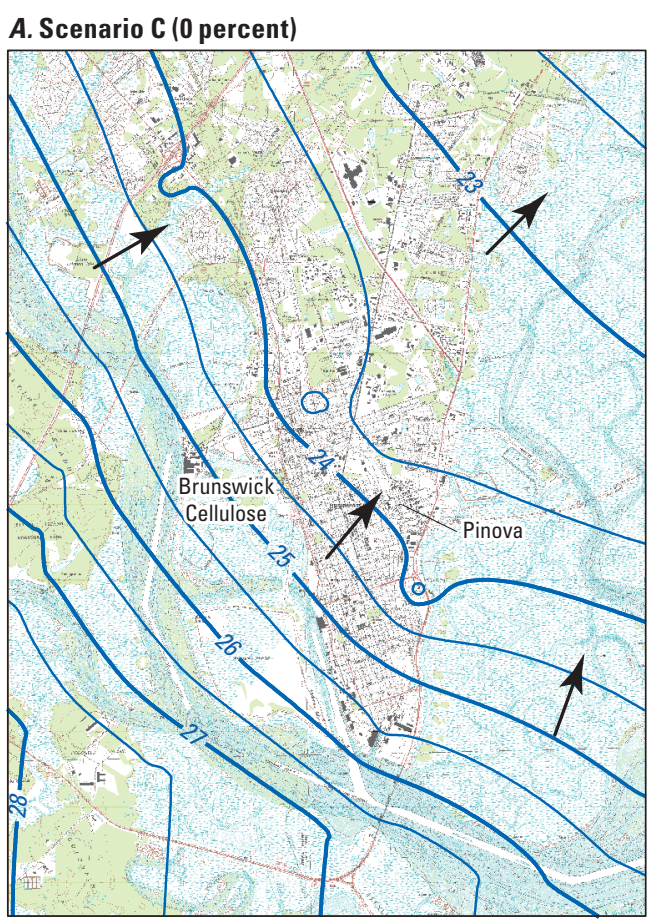

\section{Scenario D2 (25 percent)}

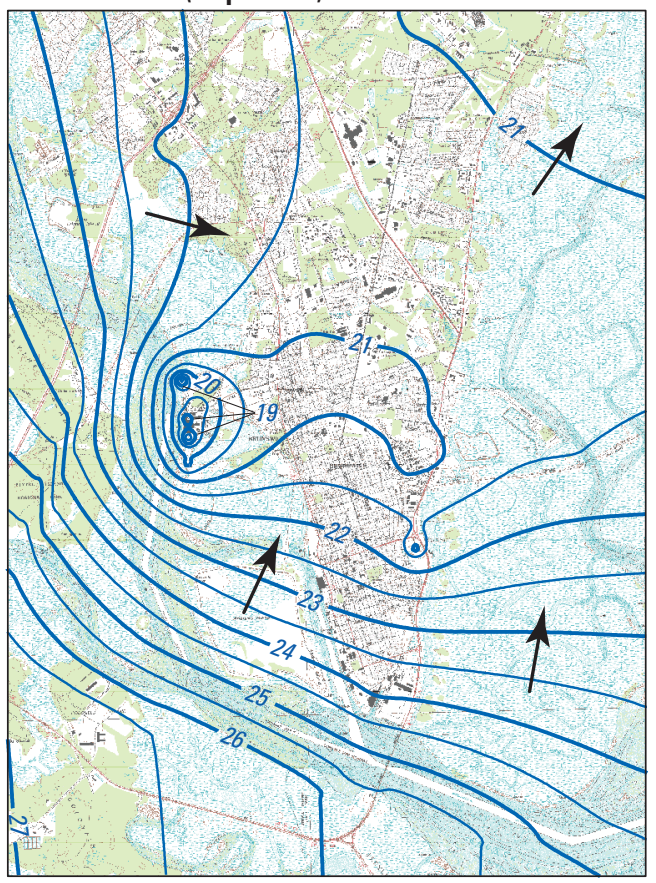

Base from U.S. Geological Survey

1:24,000-scale digital data,

Brunswick West, 1993; Brunswick East, 1979

\section{B. Scenario D1 (12.5 percent)}

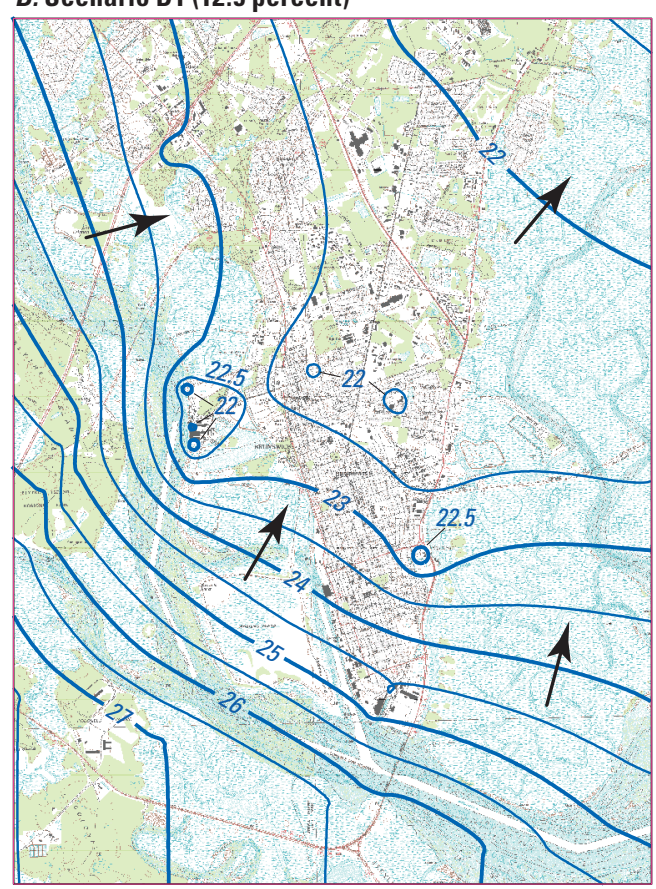

D. Scenario D3 (50 percent)

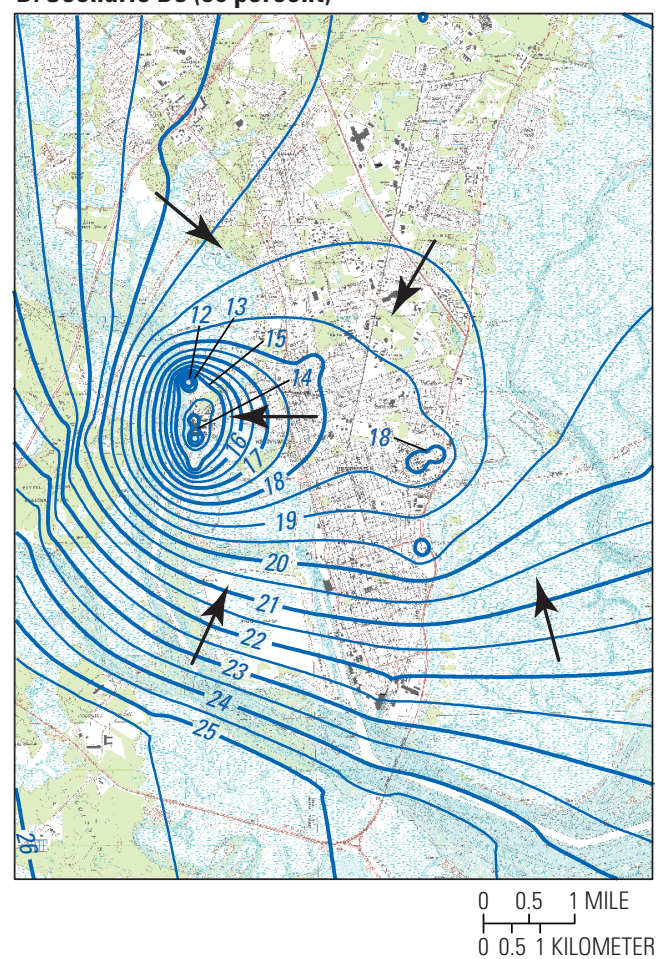

EXPLANATION

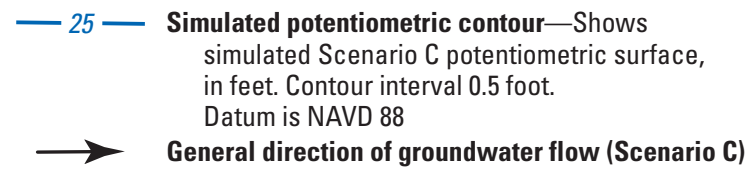

Figure 23. Maps showing simulated potentiometric surface for various percentages of industrial pumping in model layer 7 , upper water-bearing zone of the Upper Florida aquifer, Brunswick/Glynn County, Georgia: (A) Scenario C (0 percent); (B) Scenario D1 (12.5 percent); (C) Scenario D2 (25 percent); and (D) Scenario D3 (50 percent). 


\section{A. Scenario C (0 percent)}

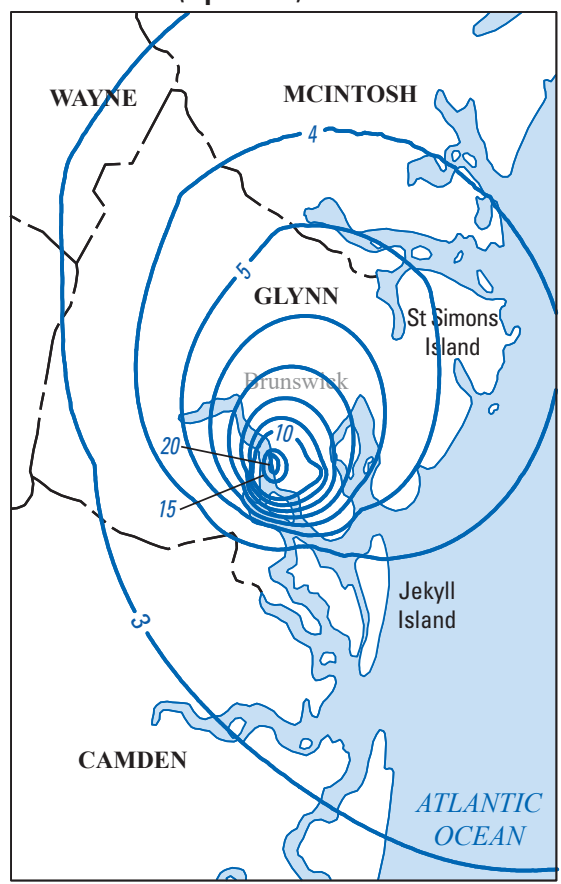

C. Scenario D2 (25 percent)

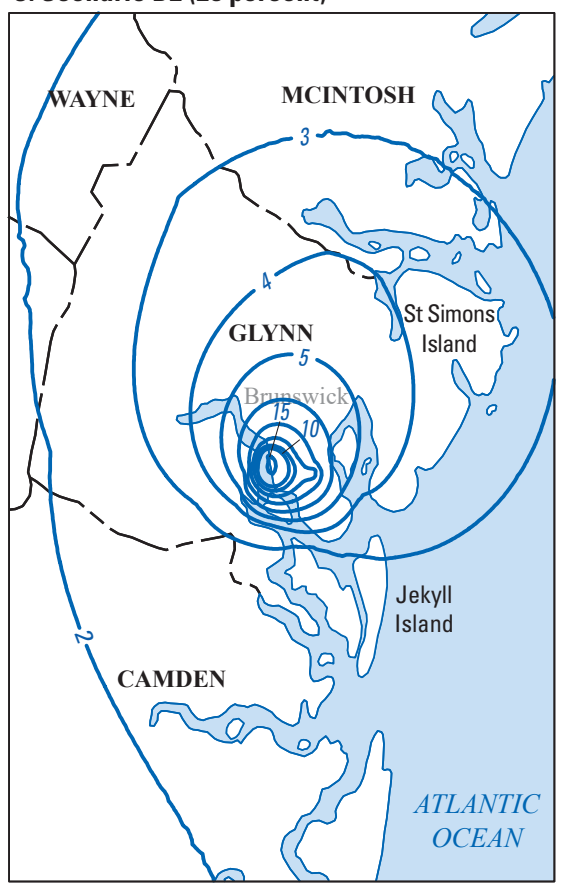

Base from U.S. Geological Survey

1:24,000-scale digital data,

Brunswick West, 1993; Brunswick East, 1979

\section{B. Scenario D1 (12.5 percent)}
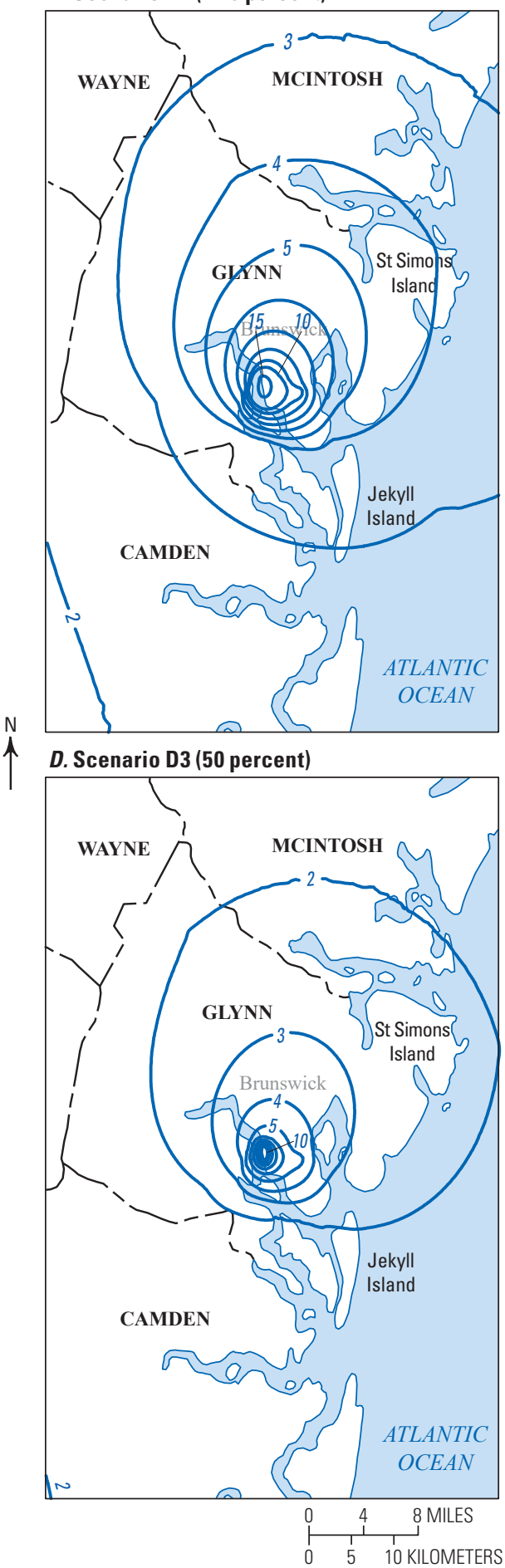

\section{EXPLANATION}

$$
\begin{aligned}
& \text { - 4- Line of equal simulated water-level change-Computed by } \\
& \text { subtracting the simulated potentiometric surface for } 2015 \\
& \text { Base Case from the simulated potentiometric surface for } \\
& \text { Scenario D. Contour interval, in feet, is variable. } \\
& \text { Datum is NAVD } 88
\end{aligned}
$$

Figure 24. Maps showing simulated water-level change from 2015 Base Case to $(A)$ Scenario $C$ (0 percent); $(B)$ Scenario D1 (12.5 percent); $(C)$ Scenario D2 (25 percent); and (D) Scenario D3 (50 percent) industrial pumping in model layer 7, upper water-bearing zone of the Upper Floridan aquifer, Brunswick/Glynn County, Georgia. 
The simulated water-level changes for Scenario D compared to 2015 Base Case indicate a range from less than $2 \mathrm{ft}$ to greater than $15 \mathrm{ft}$ within Glynn County. Scenario $\mathrm{D}$ represents variable industrial pumping with 12.5, 25, and 50 percent (designated D1, D2, and D3, respectively) of the pumping rates documented in the 2015 Base Case condition. Scenario $\mathrm{C}$ indicates the maximum simulated water-level change of greater than $25 \mathrm{ft}$ encompasses small areas within the Brunswick Cellulose well field, and the 3 - $\mathrm{ft}$ contour extends to areas outside Glynn County (fig. 24A). For 12.5 and 25 percent (Scenarios D1 and D2) of industrial pumping rates, the simulated water-level changes indicate differences of greater than $3 \mathrm{ft}$ covering most of Glynn County (fig. $24 B-C$ ). The maximum simulated water-level change for these simulations is greater than $15 \mathrm{ft}$ and covers a small area surrounding the Brunswick Cellulose well field (table 10). For the 50 percent (Scenario D3) of industrial pumping simulation, water-level changes range from $2 \mathrm{ft}$ in the western part of Glynn County to greater than $10 \mathrm{ft}$ within the Brunswick Cellulose well field (fig. 24D).

\section{Scenario E}

Scenario E represents additional pumping of $5 \mathrm{Mgal} / \mathrm{d}$ at a newly constructed Brunswick Cellulose industrial production well within the existing well field (table 9). This scenario simulates the future expansion at the Brunswick Cellulose facility and increased demand for water production from the well field (Bradford Price, Brunswick Cellulose Inc., written commun., February 2017). The new Brunswick Cellulose production well $(33 \mathrm{H} 357)$ is located about $0.2 \mathrm{mi}$ northwest of the chloride plume in the northern part of the facility. During October 2015, the Brunswick Cellulose well field had seven active production wells with a combined production of $27.9 \mathrm{Mgal} / \mathrm{d}$. The additional production well simulated for Scenario $\mathrm{E}$ increases the well field pumping rate to $32.9 \mathrm{Mgal} / \mathrm{d}$, well within the GaEPD permitted capacity of $45 \mathrm{Mgal} / \mathrm{d}$. The high pumping rates from the well field at Brunswick Cellulose create the cone of depression near downtown Brunswick and encompasses the northwest portion of the chloride plume in the UWBZ of the UFA.

The simulated results from Scenario E indicate waterlevel declines with groundwater-flow directions toward the main cone of depression in the downtown Brunswick area. For Scenario E, the potentiometric-surface map of model layer 7 (UWBZ of UFA) indicates general groundwaterflow directions from southwest to northeast in the western part of the county and from south to north near Jekyll Island (fig. 25). The addition of an industrial well pumping at a rate of $5 \mathrm{Mgal} / \mathrm{d}$ steepens the cone of depression near the Brunswick Cellulose well field. The tight spacing of the water-level contours indicates steep horizontal hydraulic-head gradients of about $7 \mathrm{ft} / \mathrm{mi}$, with groundwater-flow directions toward the center of pumping at Brunswick Cellulose. In Glynn County, groundwater not captured by pumping near downtown Brunswick flows in a northeasterly direction toward neighboring McIntosh County.

The simulated water-level changes for Scenario E compared to 2015 Base Case indicate a range from $-0.5 \mathrm{ft}$ to less than $-7 \mathrm{ft}$ and affecting most of Glynn County. The $-1.0 \mathrm{ft}$ contour extends beyond the Brunswick peninsula in a northerly direction (fig. 26). Near the chloride plume area, simulated water-level changes in model layer 7, UWBZ of the UFA, generally range between -1.5 and $-3 \mathrm{ft}$. The water-level change contours from -4 to $-7 \mathrm{ft}$ surround the simulated new production well $33 \mathrm{H} 357$ and are located on the boundary of the chloride plume. 


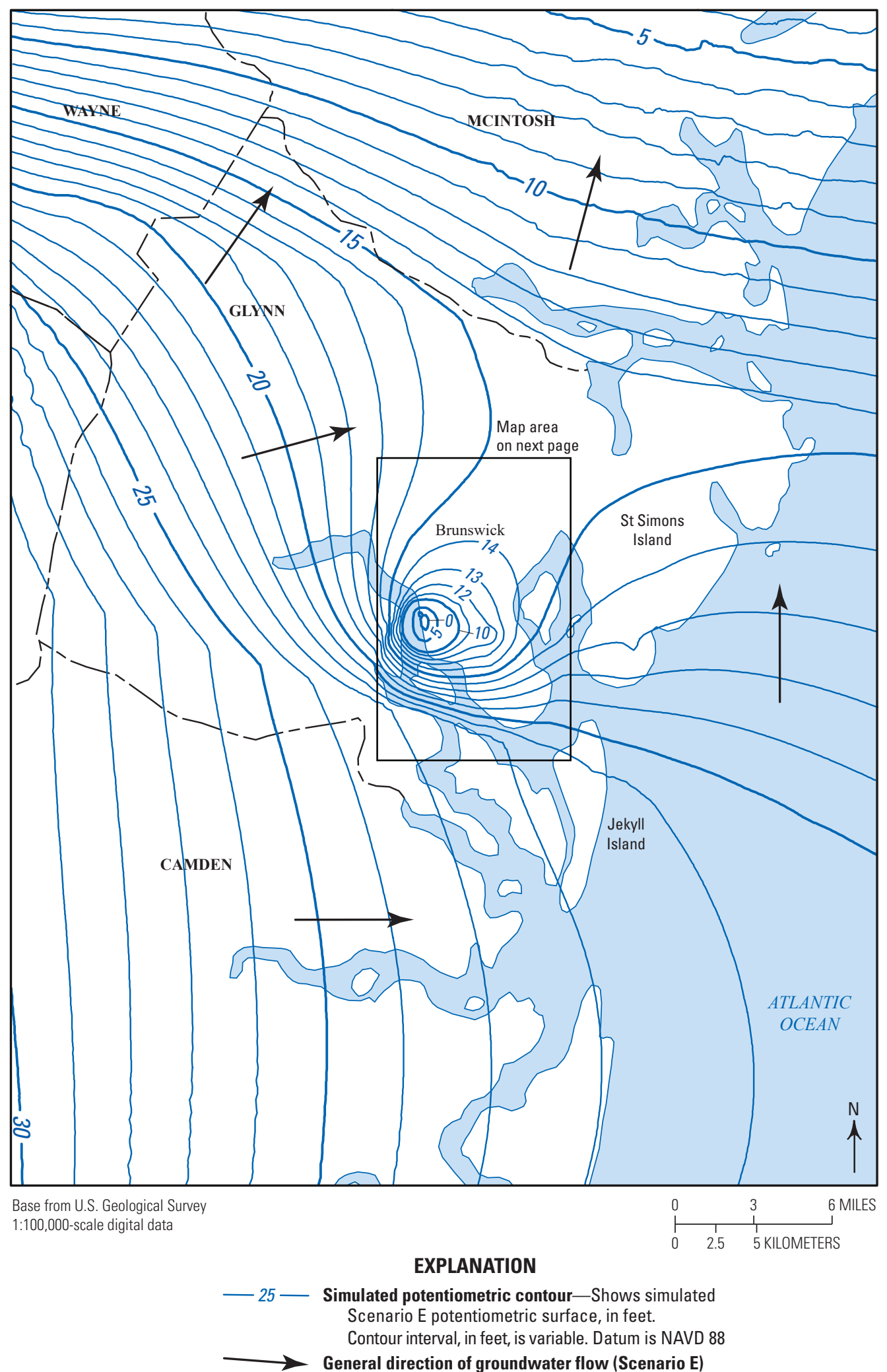

Figure 25. Maps showing Scenario E simulated potentiometric surface for model layer 7, upper water-bearing zone of the Upper Floridan aquifer, Brunswick/Glynn County, Georgia. 


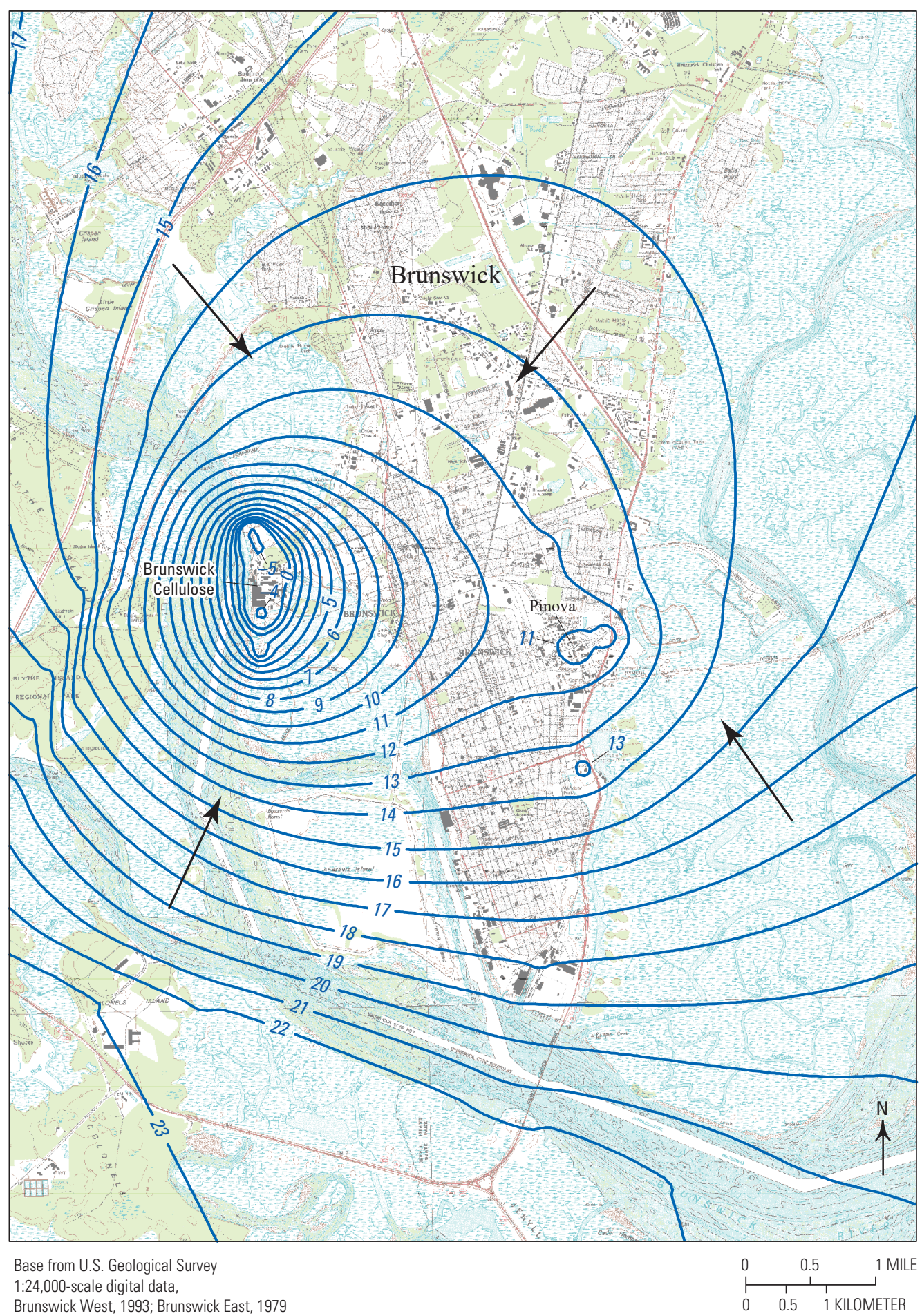

EXPLANATION

- 25 - Simulated potentiometric contour-Shows simulated Scenario $\mathrm{E}$ potentiometric surface, in feet. Contour interval 1 foot. Datum is NAVD 88

General direction of groundwater flow (Scenario E)

Figure 25. -Continued 


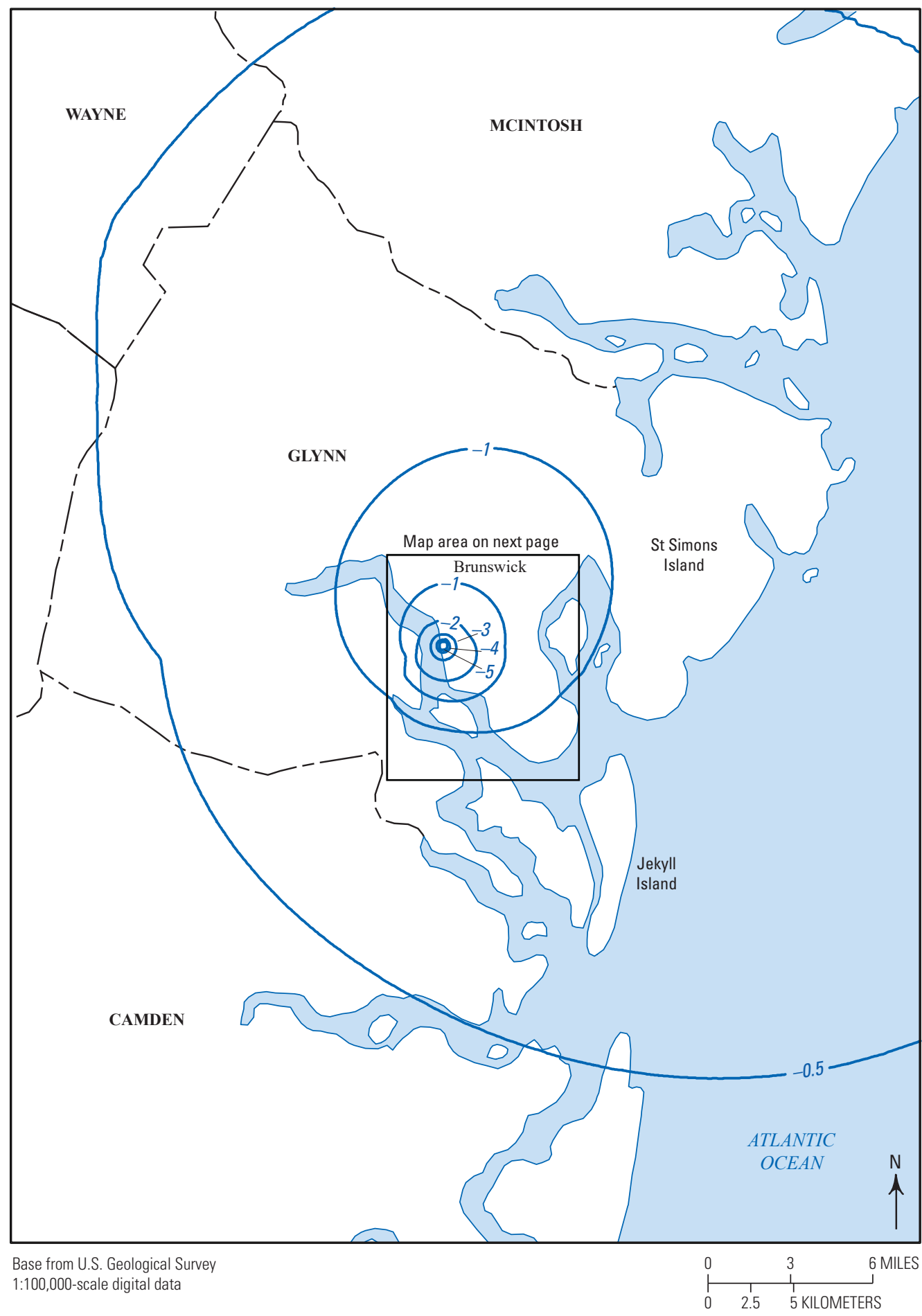

EXPLANATION

- 1 - Line of equal simulated water-level change - Computed by subtracting the simulated potentiometric surface for 2015 Base Case from the simulated potentiometric surface for Scenario E. Contour interval, in feet, is variable. Datum is NAVD 88

Figure 26. Maps showing simulated water-level change from 2015 Base Case to Scenario E in model layer 7, upper water-bearing zone of the Upper Floridan aquifer, Brunswick/Glynn County, Georgia. 


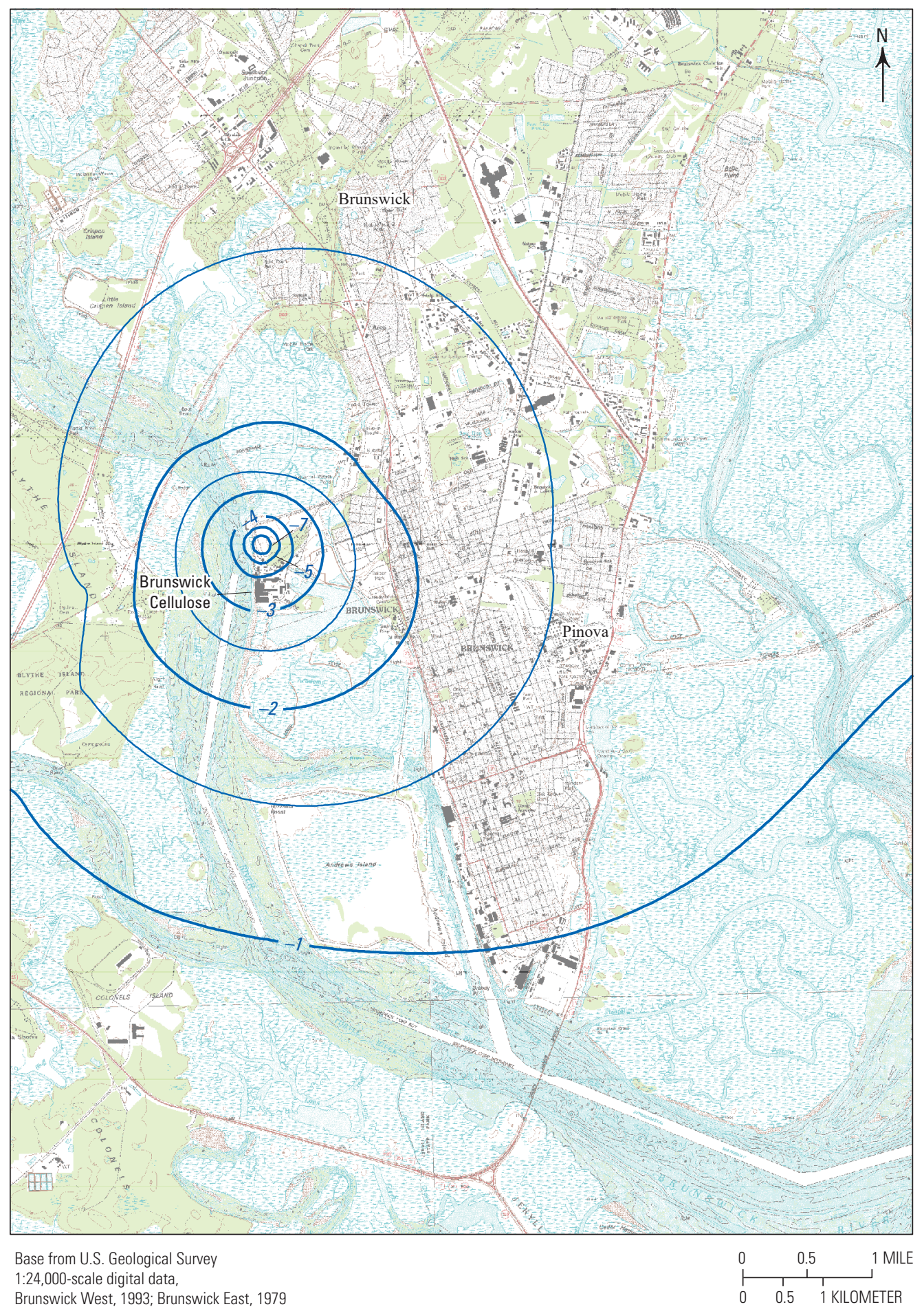

1:24,000-scale digital data

Brunswick West, 1993; Brunswick East, 1979

EXPLANATION

- -5 - Line of equal simulated water-level change - Computed by subtracting the simulated potentiometric surface for 2015 Base Case from the simulated potentiometric surface for Scenario E. Contour interval, in feet, is variable. Datum is NAVD 88

Figure 26. -Continued 


\section{Particle-Tracking Analysis}

The USGS particle-tracking code MODPATH (Pollock, 1994) was used to generate advective waterparticle pathlines and their associated time-of-travel based on MODFLOW 2015 Base Case simulation and Scenario C. The code MODPATH computes three-dimensional flow directions ( $\mathrm{x}-, \mathrm{y}-$, and $\mathrm{z}$-directions) and time-of-travel (feet per year) using particles in either a forward-tracking mode that follows the direction of groundwater flow toward groundwater discharge areas or a backtracking mode from discharge areas toward recharge areas. For the current study, MODPATH was used to assess groundwater flow in backtracking mode. For all simulations, the active aquifer model layers (layers 1, 3, $5,7,9$, and 11) were assigned a uniform effective porosity of 30 percent, and the confining units (layers 2, 4, 6, 8, and 10) were assigned a value of 50 percent to match values from the previous model (Cherry, 2015, p. 27).

Three particle seed zones were established in the BGJWSC production wells where individual particles were observed from their point of discharge toward upgradient areas at time-of-travel intervals of 20 and 50 years. The time intervals were chosen on the basis of the BGJWSC Master Plan, with forecasting to the year 2035 and an additional period to determine pathlines outside the Brunswick peninsula. The particle-tracking analysis was performed for the 2015 Base Case and Scenario $C$ to determine groundwater at a range of pumping rates and hydraulic-head gradients near the chloride plume. Eight particles were placed in each of three production wells $(34 \mathrm{H} 560,34 \mathrm{H} 449$, and $34 \mathrm{H} 445)$ at local z-direction coordinates of 0.25 and 0.75 , with 1.0 representing the top of the UWBZ of the UFA (layer 7) and 0 representing the bottom.

MODPATH results indicate that for the 2015 Base Case simulation, the dominant groundwater-flow directions are from the northeast and east (wells 34H560 and 34H449) near the northern part of the chloride plume and from the south toward well 34H445. The vertical movement of particles indicates mean upward migration ranging from 31.8 to $53.5 \mathrm{ft}$ over a 20 - year interval and 30.8 to $60.0 \mathrm{ft}$ over a 50 -year interval. Results also indicate 50 percent of the particles placed in wells 34H560 and 34H449 backtrack to either the deeper confining unit (layer 8) or the LWBZ of the UFA (layer 9). During the 20-year time-of-travel period, the total distance traveled ranged from 5,530 to $8,270 \mathrm{ft}$ with a mean distance traveled ranging from 276 to 413 feet per year (ft/yr; fig. 27; table 12). During the 50-year time-of-travel period, the total distance traveled ranged from 13,400 to $15,700 \mathrm{ft}$ with a mean distance traveled ranging from 268 to $314 \mathrm{ft} / \mathrm{yr}$. In addition, the mean yearly distance traveled was reduced from the initial 20 -year period over the final 30-year period for wells 34H560 and 34H449, which is an indication of decreases in horizontal hydraulic-head gradient further away from the chloride plume area (appendix 2).

MODPATH results indicate that for the Scenario C simulation, the dominant groundwater-flow directions are from the west and southwest (wells 34H560 and 34H449) near the northern part of the chloride plume and from the southwest and south toward well 34H445 (fig. 28). The vertical movement of particles indicates mean upward migration ranging from 66.9 to $69.4 \mathrm{ft}$ over a 20 -year interval and 82.9 to $104.1 \mathrm{ft}$ over a 50 -year interval. Results also indicate that 54 percent of the particles placed in wells $34 \mathrm{H} 560,34 \mathrm{H} 449$, and 34H445 backtrack to the LWBZ of the UFA (layer 9). During the 20-year time-of-travel period, the total distance traveled ranged from 2,510 to $3,647 \mathrm{ft}$ with a mean distance traveled ranging from 126 to $182 \mathrm{ft} / \mathrm{yr}$ (fig. 28; table 13). During the 50-year time-of-travel period, the total distance traveled ranged from 5,100 to $7,781 \mathrm{ft}$ with a mean distance traveled ranging from 89 to $156 \mathrm{ft} / \mathrm{yr}$. In addition, the mean distance traveled was reduced from the initial 20-year period over the final 30-year period for wells $34 \mathrm{H} 560,34 \mathrm{H} 449$, and $34 \mathrm{H} 445$ and is an indication of decreases in hydraulic gradient near the chloride plume area (appendix 2). 


\section{A. 20 years}

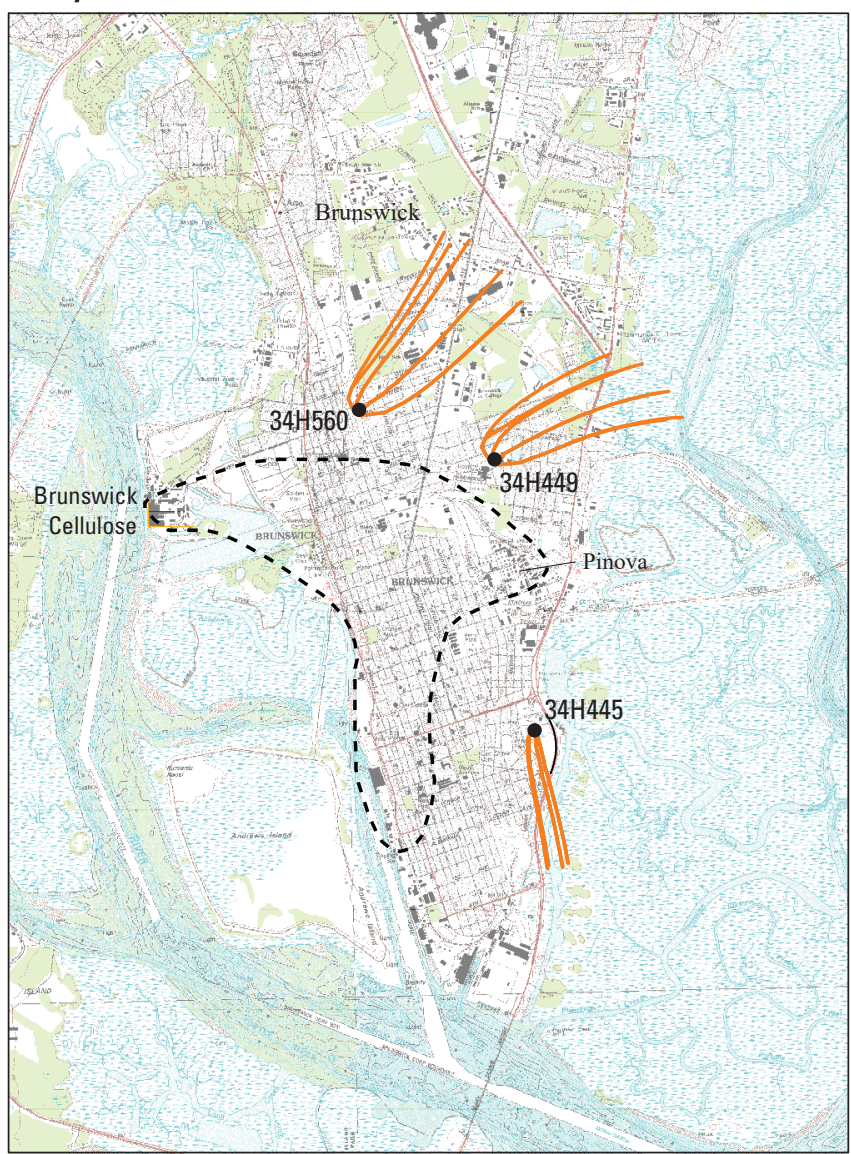

Base modified from U.S. Geological Survey 1:24,000-scale digital data,

Brunswick West, 1993; Brunswick East, 1979

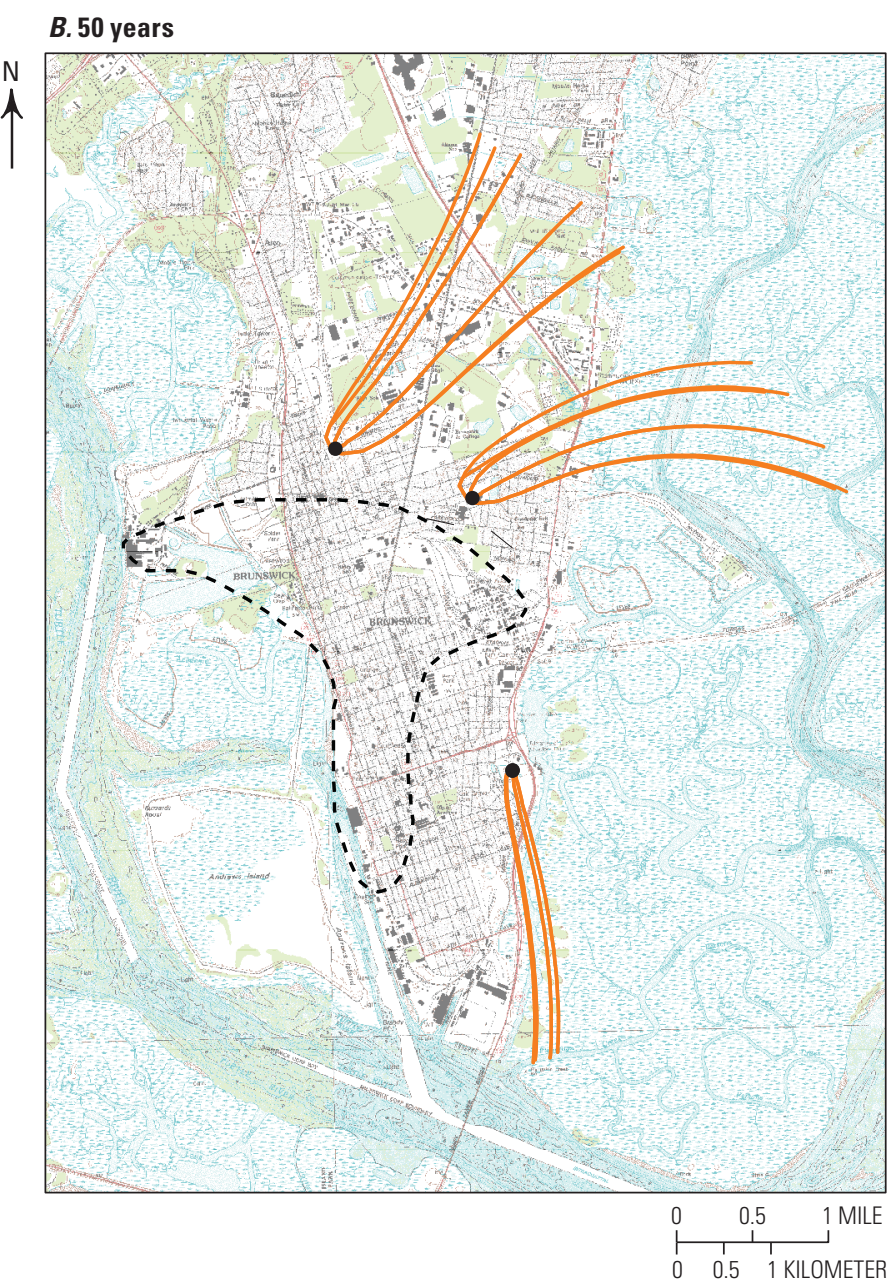

EXPLANATION

Pathline-Particle placed in active production well in layer 7

- - Chloride plume outline

$34 \mathrm{H} 445 \bullet \quad$ U.S. Geological Survey well and identifier

Figure 27. Map showing particle backtracking pathlines from the 2015 Base Case simulation with particles placed in Brunswick-Glynn County Joint Water and Sewer Commission production wells located near the chloride plume in downtown Brunswick, Georgia. 
Table 12. Results of particle backtracking from Brunswick-Glynn County Joint Water and Sewer Commission production wells toward upgradient areas for 2015 Base Case simulation in the downtown Brunswick area of Georgia.

[Max, maximum; Min, minimum; negative values indicate downward movement in the groundwater-flow system; see fig. 27 for location of particle paths; particle number paths are summarized in table 2-1]

\begin{tabular}{|c|c|c|c|c|c|c|c|c|c|c|c|c|c|c|c|c|}
\hline \multirow{3}{*}{$\begin{array}{c}\text { Well } \\
\text { identifier }\end{array}$} & \multirow{3}{*}{$\begin{array}{l}\text { Particle } \\
\text { numbers }\end{array}$} & \multicolumn{9}{|c|}{ Particle movement, in feet } & \multicolumn{6}{|c|}{ Particle movement, in feet } \\
\hline & & \multicolumn{3}{|c|}{$x$-direction } & \multicolumn{3}{|c|}{ y-direction } & \multicolumn{3}{|c|}{ z-direction } & \multicolumn{3}{|c|}{ Total distance traveled } & \multicolumn{3}{|c|}{ Yearly distance traveled } \\
\hline & & Max & Min & Mean & Max & Min & Mean & Max & Min & Mean & Max & Min & Mean & Max & Min & Mean \\
\hline \multicolumn{17}{|c|}{ Time-of-travel, 20 years } \\
\hline $34 \mathrm{H} 560$ & $1-8$ & 3,876 & 804 & 2,251 & 6,939 & 4,902 & 5,987 & -7.56 & -70.74 & -31.80 & 9,464 & 7,312 & 8,270 & 473 & 366 & 413 \\
\hline $34 \mathrm{H} 449$ & $9-16$ & 5,493 & 2,611 & 3,992 & 4,917 & 3,449 & 4,178 & -17.44 & -88.82 & -40.55 & 9,246 & 7,029 & 8,210 & 462 & 351 & 411 \\
\hline $34 \mathrm{H} 445$ & $17-24$ & 3,617 & 430 & 2,126 & 4,440 & 1,220 & 3,350 & -26.17 & -150.44 & -53.51 & 6,680 & 3,394 & 5,529 & 334 & 170 & 276 \\
\hline \multicolumn{17}{|c|}{ Time-of-travel, 50 years } \\
\hline $34 \mathrm{H} 560$ & $1-8$ & 6,826 & 1,071 & 3,846 & 12,091 & 9,456 & 10,862 & -16.90 & -81.07 & -47.57 & 16,988 & 13,193 & 14,756 & 340 & 264 & 295 \\
\hline $34 \mathrm{H} 449$ & $9-16$ & 12,001 & 7,608 & 9,461 & 7,839 & 4,724 & 6,166 & -35.25 & -105.03 & -60.01 & 16,825 & 13,300 & 15,688 & 337 & 266 & 314 \\
\hline $34 \mathrm{H} 445$ & $17-24$ & 4,707 & 4,289 & 4,463 & 9,207 & 8,694 & 8,920 & -24.78 & -40.94 & -30.76 & 13,569 & 13,264 & 13,413 & 271 & 265 & 268 \\
\hline
\end{tabular}




\section{A. 20 years}

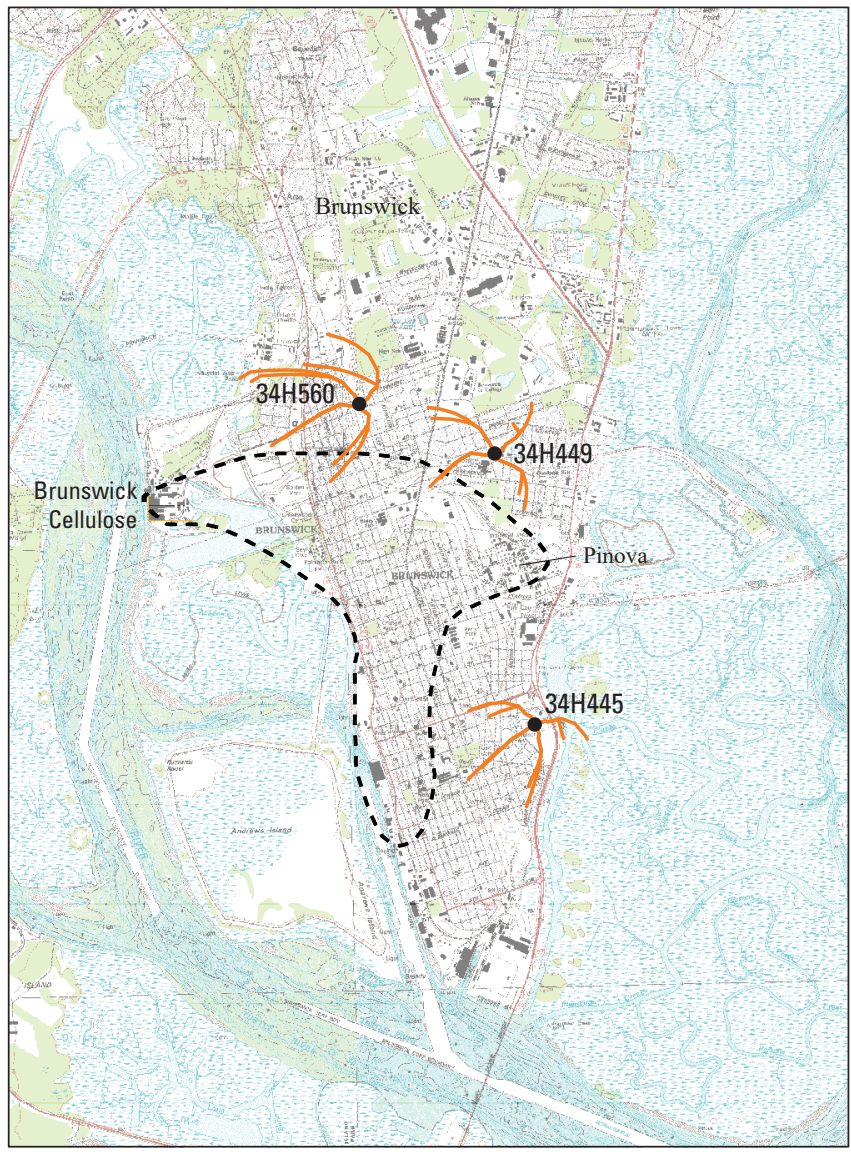

Base from U.S. Geological Survey

1:24,000-scale digital data,

Brunswick West, 1993; Brunswick East, 1979

\section{B. 50 years}

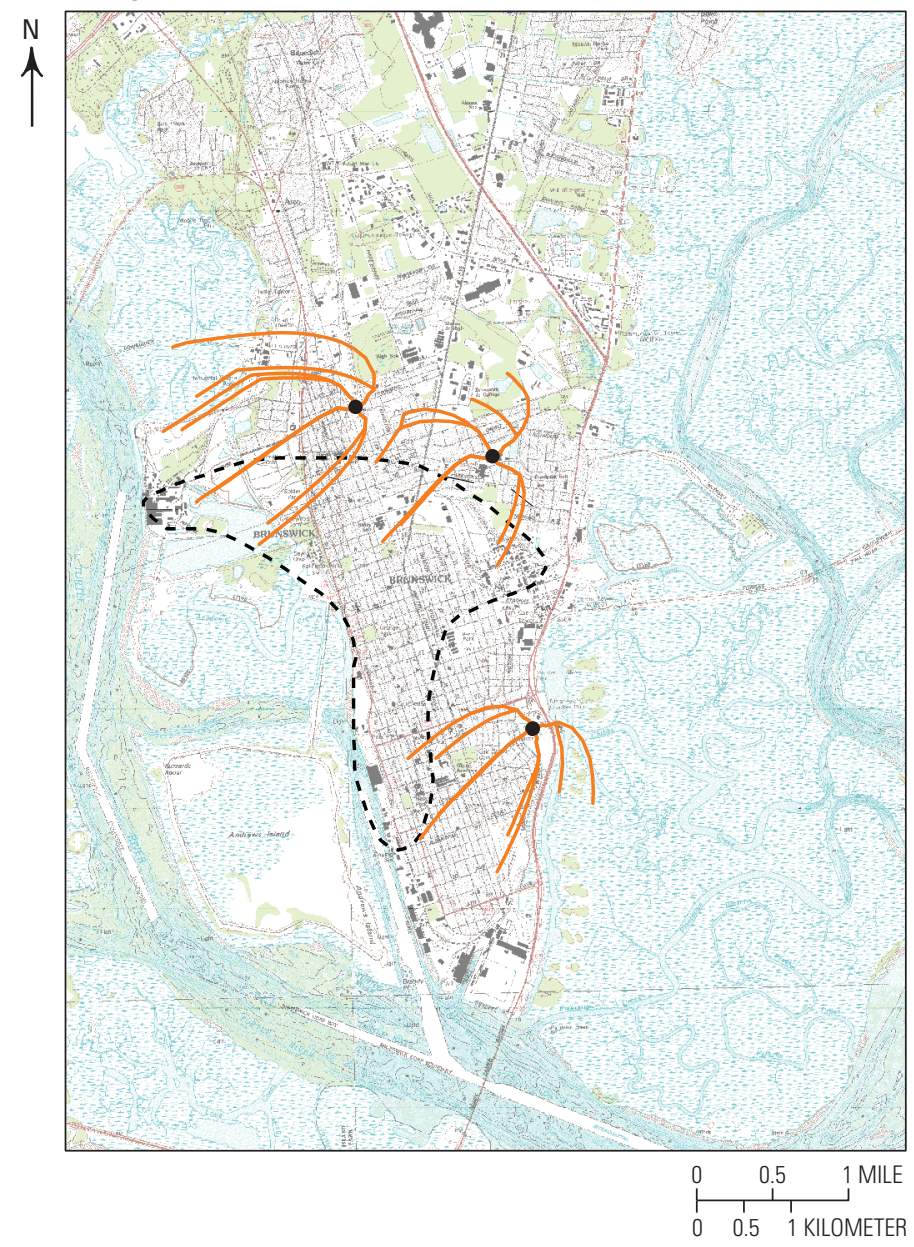

\section{EXPLANATION}

— Pathline-Particle placed in active production well in layer 7

-- Chloride plume outline

$34 \mathrm{H} 445 \bullet \quad$ U.S. Geological Survey well and identifier

Figure 28. Map showing particle backtracking pathlines from the Scenario C simulation with particles placed in Brunswick-Glynn County Joint Water and Sewer Commission production wells located near the chloride plume in downtown Brunswick, Georgia. 
Table 13. Results of particle backtracking from Brunswick-Glynn County Joint Water and Sewer Commission production wells toward upgradient areas for Scenario C simulation in the downtown Brunswick area of Georgia.

[Max, maximum; Min, minimum; negative values indicate downward movement in the groundwater-flow system; see fig. 28 for location of particle paths; particle number paths are summarized in table 2-1]

\begin{tabular}{|c|c|c|c|c|c|c|c|c|c|c|c|c|c|c|c|c|}
\hline \multirow{3}{*}{$\begin{array}{c}\text { Well } \\
\text { identifier }\end{array}$} & \multirow{3}{*}{$\begin{array}{l}\text { Particle } \\
\text { numbers }\end{array}$} & \multicolumn{9}{|c|}{ Particle movement, in feet } & \multicolumn{6}{|c|}{ Particle movement, in feet } \\
\hline & & \multicolumn{3}{|c|}{$x$-direction } & \multicolumn{3}{|c|}{$y$-direction } & \multicolumn{3}{|c|}{ z-direction } & \multicolumn{3}{|c|}{ Total distance traveled } & \multicolumn{3}{|c|}{ Yearly distance traveled } \\
\hline & & Max & Min & Mean & Max & Min & Mean & Max & Min & Mean & Max & Min & Mean & Max & Min & Mean \\
\hline \multicolumn{17}{|c|}{ Time-of-travel, 20 years } \\
\hline $34 \mathrm{H} 560$ & $1-8$ & 3,964 & 148 & 2,028 & 2,677 & 477 & 1,553 & -33.02 & -124.61 & -66.91 & 4,704 & 2,441 & 3,647 & 235 & 122 & 182 \\
\hline $34 \mathrm{H} 449$ & $9-16$ & 2,537 & 117 & 1,360 & 1,929 & 267 & 1,122 & -28.81 & -119.09 & -68.02 & 3,267 & 1,279 & 2,550 & 163 & 64 & 128 \\
\hline $34 \mathrm{H} 445$ & $17-24$ & 2,162 & 361 & 1,206 & 2,591 & 25 & 1,235 & -30.03 & -138.94 & -69.44 & 3,823 & 1,302 & 2,510 & 158 & 65 & 126 \\
\hline \multicolumn{17}{|c|}{ Time-of-travel, 50 years } \\
\hline $34 \mathrm{H} 560$ & $1-8$ & 6,807 & 1,690 & 4,314 & 5,340 & 422 & 3,383 & -43.80 & -147.10 & -82.94 & 9,139 & 6,391 & 7,781 & 183 & 128 & 156 \\
\hline 34H449 & $9-16$ & 3,619 & 591 & 1,979 & 3,857 & 315 & 2,355 & -39.25 & -167.21 & -104.08 & 6,395 & 3,065 & 4,437 & 128 & 61 & 89 \\
\hline $34 \mathrm{H} 445$ & $17-24$ & 3,635 & 230 & 1,891 & 4,668 & 1,783 & 3,116 & -37.51 & -180.71 & -84.84 & 7,002 & 3,401 & 5,092 & 140 & 68 & 102 \\
\hline
\end{tabular}




\section{Limitations of Digital Simulation}

The revised groundwater-flow model (Cherry, 2015) developed for the Brunswick/Glynn County area is subject to uncertainties inherent in groundwater models, including those documented for the original model by Payne and others (2005). The reader is referred to Payne and others (2005) for a complete discussion of the model limitations; those that relate to the modifications of the model are discussed in this section. A model is a simplification of a complex hydrogeologic system and is limited by the number of data points used to construct the framework of the model.

The original model was constructed to simulate groundwater flow in the Floridan aquifer system, which encompasses parts of Georgia, South Carolina, Alabama, and all of Florida. Decisions were made early on in the development of the model as to the spatial representation of the hydrogeologic units and discretization of the model layers. In the design phase of the original model, it was determined a specified-head boundary would be used to represent the Floridan aquifer system near the Florida/Georgia State boundary to allow groundwater flow to enter and exit the model in this region. It was impractical to include the Floridan aquifer system in Alabama and Florida when the focus of the study is the groundwater-flow regime in coastal Georgia.

The original model by Payne and others (2005) discretized the model grid cells into large $16,500 \mathrm{x}$ 16,500 -ft blocks along the edges of the model, with smaller grid cells in the study focus areas for the cities of Savannah and Brunswick. It became apparent when evaluating the model for localized scenarios in the Brunswick/Glynn County area that these grid-cell dimensions were not small enough to accurately simulate the cone of depression in the Brunswick area. A determination was made after some trial and error that a $500 \times 500$-ft grid cell was sufficient to simulate pumping in the UFA for the Brunswick area. Limits on computational space and model run times required the elimination of the finer grid mesh near the city of Savannah and affected the model calibration.

The UFA was modeled as one unit (model layer 5) in the original model by Payne and others (2005); however, the hydrogeology in the Brunswick/Glynn County area indicated there are two water-bearing units within the aquifer. On the basis of local hydrogeology, the UFA was subdivided into the UWBZ (model layer 7), intervening confining unit (model layer 8), and the LWBZ (model layer 9). This configuration is used in the Brunswick/Glynn County area and extends out to include hydraulic-property geographic zones F7 and F8, which encompasses Camden County to the south. Beyond these hydraulic-property geographic zones, the intervening confining unit was assigned the same hydraulic conductivity as the model layers above and below due to the uncertainty in the extent of distinct water-bearing zones of the UFA. The observation data for the LWBZ of the UFA (model layer 9) were limited to five wells and proved difficult to match the observed heads to the simulated heads in both 2004 and
2015. In general, the simulated heads were lower than those observed for 2004 and matched reasonably well in 2015 . This could be caused in part by the pumping distribution between model layers 7 and 9, which assigned pumping rates on the basis of aquifer thickness in 2004 and assigned a higher rate of pumping from model layer 7 in 2015 on the basis of additional well data.

The groundwater-flow model was calibrated to hydrologic conditions during June 2004 and October 2015 using steady-state simulations. This type of simulation does not take into account small-scale changes and seasonal responses to recharge and pumping. To simulate a short-term response in the flow system, a transient simulation would be required along with greater temporal resolution of stresses, boundary conditions, and observation data (Payne and others, 2005).

Boundary conditions play an important role in the calibration of the model, but are also a large source of uncertainty. The flow budgets for the groundwater-flow model indicate the specified-head boundaries in model layers 7-11 account for nearly 80 percent of the inflows and about 60 percent of the outflows. The specified-head boundary becomes the simulated recharge to the groundwater system and can be increased by increasing pumping. The observed head data for 2004 were limited but were used to assign specified-head values along the extent of the boundary. Caution should be used in assuming that the specified-head boundary will supply limitless quantities of water in response to pumping and cannot be constrained by assigning recharge to specific areas of the model.

Pumping uncertainty results from limited or improper metering, errors in reporting, overestimating or underestimating countywide water use, and assigning the pumping to the wrong unit or model layer. If large discrepancies exist between site specific and non-site specific data, then non-site specific wells will be assigned higher pumping rates. This could in turn affect the assigned hydraulic-property data to a given area of the model.

The model is limited by the wide range of hydraulic conductivity assigned to the UFA (model layers 7 and 9). The values assigned to these groundwater-flow model layers assigned by Cherry (2015) range from 20 to 3,415 feet per day $(\mathrm{ft} / \mathrm{d})$ with an average of $540 \mathrm{ft} / \mathrm{d}$. According to a sensitivity analysis conducted by Payne and others (2005), additional hydraulic conductivity data for the UFA in hydraulicproperty geographic zones F4, F5, and F6 (fig. 9) may help improve model accuracy. The analysis also indicates that additional vertical hydraulic conductivity (layer 6 and parts of layers 2, 3, 4, and 5) data also could improve model accuracy and calibration.

The accuracy of MODPATH and associated pathlines depends on the extent to which the groundwater system can be realistically represented by a discrete network of finite-difference cells (Pollack, 1994). The analyses using MODPATH, however, were limited to the Brunswick peninsula, where the grid has the highest resolution within the model. 


\section{Summary}

In the Brunswick, Georgia, area, saltwater has been contaminating the Upper Floridan aquifer (UFA) since the late 1950s and has constrained development of the aquifer within an area of several square miles in the downtown area. In this area, parts of the aquifer produce water that has a chloride concentration greater than 2,000 milligrams per liter $(\mathrm{mg} / \mathrm{L})$, which is above the $250-\mathrm{mg} / \mathrm{L}$ State and Federal secondary drinking-water standard. Further development of the UFA is limited to areas outside the chloride plume in a manner that will minimize future expansion of the plume and maintain horizontal hydraulic-head gradients toward active pumping centers in the area. To provide information to help manage water resources in the Brunswick area, the U.S. Geological Survey (USGS), in cooperation with the Brunswick-Glynn County Joint Water and Sewer Commission (BGJWSC) and the Georgia Environmental Protection Division (GaEPD), performed groundwater modeling simulations focused on hydraulic-head gradients in the vicinity of the chloride plume.

This report describes the results of simulations used to revise a regional MODFLOW groundwater-flow model of coastal Georgia and adjacent parts of Florida and South Carolina to evaluate a 2015 Base Case by using adjusted pumping rates in the Brunswick/St. Simons Island area. The revised recalibrated groundwater-flow model was used to evaluate seven groundwater-management scenarios with adjusted pumping rates in production wells located in the Brunswick/Glynn County area. The original model for the Brunswick/Glynn County area was modified because the discretization of 4,000 by 5,000 feet (ft) was not fine enough to simulate drawdown near active industrial production wells. The determination was made after some trial and error that grid cells with dimensions of $500 \mathrm{ft}$ per side were adequate for the revised model to simulate large-scale pumping near downtown Brunswick.

For the revised model, additional hydraulic-property geographic zones were designated on the basis of available aquifer-test and geologic data. Three additional hydraulicproperty geographic zones were created within the UFA (layers 7-9) near the Brunswick area to improve calibration of the original model. The Brunswick aquifer system (model layer 3 in the original model) was subdivided in the revised model to include the upper and lower Brunswick aquifers (layers 3 and 5). The UFA (model layer 5 in the original model) was subdivided in the revised model to include the upper and lower water-bearing zones (UWBZ and LWBZ) of the UFA (model layers 7 and 9). The subdivision of the UFA, however, was limited to Glynn and Camden County areas because of the uncertainty in extent of these units throughout the regional model area. The intervening confining units for the Brunswick aquifer system and UFA corresponded to layers 4 and 8 in the revised model.

The revised model was calibrated for 2004 and 2015 conditions on the basis of differences (residuals) between simulated heads and observed water levels as well as their corresponding mean, median, and root-mean-square error
(RMSE) statistics. For the 2004 calibration, residuals in the Brunswick/Glynn County area from 32 observation wells in model layer 7, UWBZ of the UFA, ranged from -18.9 to $3.98 \mathrm{ft}$, with a mean of $-2.56 \mathrm{ft}$, median of $-1.50 \mathrm{ft}$, and an RMSE of $5.34 \mathrm{ft}$. The distribution of water-level residuals in the UWBZ of the UFA (layer 7) indicates an acceptable match, with 75 percent of the values within the established error criterion of $5 \mathrm{ft}$. For the 2015 calibration, residuals in the Brunswick/Glynn County area from 26 observation wells in model layer 7, UWBZ of UFA, ranged from -17.3 to $5.48 \mathrm{ft}$, with a mean of $-0.25 \mathrm{ft}$, median of $1.00 \mathrm{ft}$, and an RMSE of $4.89 \mathrm{ft}$. The distribution of water-level residuals in the UWBZ of the UFA (layer 7) indicates an acceptable match, with 81 percent of the values within the established error criterion of $5 \mathrm{ft}$. In the steady-state models for 2004 and 2015, simulated water-level increases in the UFA (layers 7 and 9) were caused by decreases in pumping rates, with groundwaterlevel increases generally ranging between 1 and $7 \mathrm{ft}$. During 2004, simulated potentiometric gradients ranged between 7.6 and 11.0 feet per mile (ft/mi) in profiles near the Brunswick Cellulose well field and $3.6 \mathrm{ft} / \mathrm{mi}$ in a profile oriented in a general north to south direction. During the 2015 Base Case, lower pumping rates reduced hydraulic-head gradients, which ranged between 6.7 and $9.8 \mathrm{ft} / \mathrm{mi}$ in profiles near the Brunswick Cellulose well field and $2.8 \mathrm{ft} / \mathrm{mi}$ in the profile oriented in a north to south direction.

Simulated water budgets in the Brunswick/Glynn County area indicate total pumping of 55.2 million gallons per day (Mgal/d) during 2004 and 45.2 Mgal/d during 2015 in the UWBZ and LWBZ of the UFA (model layers 7 and 9). Inflows and outflows are predominantly across county boundaries, with outflows to the general-head boundary in model layer 1 of $5.8 \mathrm{Mgal} / \mathrm{d}$ during 2004 and $6.3 \mathrm{Mgal} / \mathrm{d}$ during 2015, respectively. For the 2004 simulation, $19.6 \mathrm{Mgal} / \mathrm{d}$ of pumping was assigned to model layer 7 (UWBZ of the UFA) and 34.1 Mgal/d to model layer 9 (LWBZ of the UFA). For the 2015 Base Case simulation, greater pumping of $31.2 \mathrm{Mgal} / \mathrm{d}$ was assigned to model layer 7 on the basis of depth of production wells in the study area. An additional $12.4 \mathrm{Mgal} / \mathrm{d}$ of pumping was assigned to model layer 9 on the basis of well information that includes five production wells that tap the LWBZ of the UFA.

The revised calibrated 2015 Base Case regional model was used to simulate the potential effect of seven distinct groundwater-management scenarios in the Brunswick/ St. Simons Island area. Two scenarios (Scenarios A and B) simulate additional pumping at existing public-supply wells located near the chloride plume and planned publicsupply wells located to the north. Scenario C simulates the deactivation of industrial production wells totaling 31.3 Mgal $/ \mathrm{d}$ of pumping. Scenario D consists of three scenarios, which simulate $12.5,25$, and 50 percent (designated D1, D2, and D3, respectively) of the $31.3 \mathrm{Mgal} / \mathrm{d}$ pumping rates at the Brunswick Cellulose and Pinova industrial facilities, to determine changes in horizontal hydraulic-head gradients within the chloride plume. Scenario E simulates pumping rates of $5 \mathrm{Mgal} / \mathrm{d}$ at a recently constructed industrial production well within the Brunswick Cellulose well field. 
The simulated results from Scenario A indicate minor water-level declines with groundwater-flow directions remaining similar to those of the 2015 Base Case condition in the UWBZ of the UFA (layer 7). In the Scenario B simulation, moderate water-level declines were observed with groundwater-flow directions more pronounced toward the northeastern part of Glynn County. The simulated change in heads within the chloride plume area generally ranged between -1.0 and $-1.5 \mathrm{ft}$. In the Scenario B simulation, potentiometric gradients in four profiles near the Brunswick Cellulose well field ranged between 6.6 and $9.7 \mathrm{ft} / \mathrm{mi}$ and were $2.9 \mathrm{ft} / \mathrm{mi}$ in a profile oriented in a general north to south direction. In the Scenario $\mathrm{C}$ simulation, elimination of 31.3 Mgal/d of pumping at Brunswick Cellulose and Pinova shifted groundwater-flow direction toward pumping centers from the north and east. This scenario also shifted flow paths across the Brunswick peninsula from the southwest toward the northeast. The simulated water-level changes for Scenario C compared to 2015 Base Case indicate a range from $+3 \mathrm{ft}$ to greater than $+25 \mathrm{ft}$ in Glynn County. In close proximity and inside the chloride plume, water-level changes ranged from $+6.00 \mathrm{ft}$ in well $34 \mathrm{H} 095$ to $+22.4 \mathrm{ft}$ in well $33 \mathrm{H} 211$. Simulated potentiometric gradients for Scenario $\mathrm{C}$ in the three potentiometric profiles constructed in close proximity to the Brunswick Cellulose well field show horizontal hydraulic-head gradients changing to 0.4 to $0.9 \mathrm{ft} / \mathrm{mi}$ due to discontinued pumping with groundwater-flow direction toward the northwest, east, and southeast. In the Scenario D1-D3 simulations, varying pumping rates of $31.3 \mathrm{Mgal} / \mathrm{d}$ of pumping at the Brunswick Cellulose and Pinova well fields by 12.5 , 25 , and 50 percent altered potentiometric gradients toward pumping centers from the north and east. These scenarios also shift flow paths across the Brunswick peninsula from the southwest toward the northeast. The simulated water-level changes for Scenario C compared to 2015 Base Case indicate a range from $+3 \mathrm{ft}$ to greater than $+15 \mathrm{ft}$ within Glynn County. Simulated potentiometric gradients for Scenarios D1-D3 in the four potentiometric profiles constructed in close proximity to the Brunswick Cellulose well field show horizontal hydraulic-head gradients ranging from 0.2 to $4.5 \mathrm{ft} / \mathrm{mi}$ due to changing pumping rates within the Brunswick Cellulose well field with groundwater-flow directions toward the northeast, west, and southwest. In the Scenario E simulation, results indicate general groundwater-flow directions from southwest to northeast in the western part of the county and from south to north near Jekyll Island. Near the chloride plume, simulated water-level changes from the 2015 Base Case in model layer 7 , UWBZ of UFA, generally ranged between -1.5 and $-3 \mathrm{ft}$. Water-level change contours from -4 to $-7 \mathrm{ft}$ surround the simulated production well and are located on the boundary of the northwestern part of the chloride plume.

MODPATH results indicate that for the 2015 Base Case simulation, particle backtracking from wells 34H560, 34H449 and $34 \mathrm{H} 445$ over a 20 -year time-of-travel period show total distance traveled ranging from 5,529 to 8,270 ft with a mean annual distance traveled ranging from 276 to $413 \mathrm{ft}$. During the 50-year time-of-travel period, the total distance traveled ranged from 13,413 to $15,688 \mathrm{ft}$ with a mean annual distance traveled ranging from 268 to $314 \mathrm{ft}$. In the Scenario C simulation, results from particle backtracking at the same wells show dominant groundwater-flow directions are from the west and southwest in wells $34 \mathrm{H} 560$ and 34H449 and from the southwest and south toward well $34 \mathrm{H} 445$. The total distance traveled over a 20-year period ranged from 2,510 to $3,647 \mathrm{ft}$ with a mean annual distance traveled ranging from 126 to $182 \mathrm{ft}$. During the 50-year time-of-travel period, the total distance travelled ranged from 5,092 to 7,781 ft with a mean annual distance traveled ranging from 89 to $156 \mathrm{ft}$. The changes in the distance traveled between the separate simulations are attributable to decreases in hydraulic-head gradient near the chloride plume area.

\section{References Cited}

Applied Coastal Research Laboratory, Georgia Southern University, 2002, Gulf Trough and Satilla Line data analysis: Georgia Geologic Survey Project Report 48, 15 p.

Applied Technology \& Management, 2016, Brunswick-Glynn County Joint Water and Sewer Commission Master Plan Update 2015-2035: Applied Technology \& Management, $271 \mathrm{p}$.

Cherry, G.S., 2007, U.S. Geological Survey Georgia Water Science Center and City of Brunswick-Glynn County Cooperative Water Program-Summary of activities, July 2005 through June 2006: U.S. Geological Survey Open-File Report 2006-1368, 64 p. [Also available at https://doi.org/10.3133/ofr20061368.]

Cherry, G.S., 2015, Groundwater flow in the Brunswick/ Glynn County area, Georgia, 2000-04: U.S. Geological Survey Scientific Investigations Report 2015-5061, 88 p., https://doi.org/10.3133/sir20155061.

Cherry, G.S., 2019, MODFLOW-2000 and MODPATH used to evaluate groundwater-management scenarios in the Brunswick area, Georgia, 2004-2015: U.S. Geological Survey data release, https://doi.org/10.5066/P9RTSIJJ.

Cherry, G.S., and Clarke, J.S., 2008, Groundwater conditions and studies in the Brunswick-Glynn County area, Georgia, 2007: U.S. Geological Survey OpenFile Report 2008-1297, 42 p. [Also available at https://doi.org/10.3133/ofr20081297.]

Cherry, G.S., and Peck, M.F., 2017, Saltwater intrusion in the Floridan aquifer system near downtown Brunswick, Georgia, 1957-2015: U.S. Geological Survey OpenFile Report 2017-2010, 10 p. [Also available at https://doi.org/10.3133/ofr20171010.] 
Cherry, G.S., Peck M.F., Painter, J.A., and

Stayton, W.L., 2010, Groundwater conditions and studies in the Brunswick-Glynn County area, Georgia, 2008:

U.S. Geological Survey Open-File Report 2009-1275, 54 p. [Also available at https://doi.org/10.3133/ofr20091275.]

Cherry, G.S., Peck M.F., Painter, J.A., and

Stayton, W.L., 2011, Groundwater conditions and studies in the Brunswick-Glynn County area, Georgia, 2009: U.S. Geological Scientific Investigations Report 2011-5087, 58 p., accessed on April 3, 2018, at https://pubs.usgs.gov/sir/2011/5087/.

Clarke, J.S., 2003, The surficial and Brunswick aquifer systems-Alternative ground-water resources for coastal Georgia, in Hatcher, K.J., ed., Proceedings of the 2003 Georgia Water Resources Conference, April 23-24, 2003: Athens, Ga., University of Georgia, Institute of Ecology, CD-ROM. [Also available at https://www2.usgs.gov/water/ southatlantic/ga/publications/other/gwrc2003/pdf/ClarkeGWRC2003.pdf.]

Clarke, J.S., Cherry, G.S., and Gonthier, G.J., 2011, Hydrogeology and water quality of the Floridan aquifer system and effects of Lower Floridan aquifer pumping on the Upper Floridan aquifer at Fort Stewart, Georgia: U.S. Geological Survey Scientific Investigations Report 2011-5065, 59 p. [Also available at https://doi.org/10.3133/sir20115065.]

Clarke, J.S., Hacke, C.M., and Peck, M.F., 1990, Geology and groundwater resources of the coastal area of Georgia: Georgia Geologic Survey Bulletin 113, 106 p. [Also available at https://www2.usgs.gov/water/southatlantic/ga/ publications/ggs/bull-113/.]

Clarke, J.S., and Krause, R.E., 2000, Design, revision, and application of ground-water flow models for simulation of selected water-management scenarios in the coastal area of Georgia and adjacent parts of South Carolina and Florida: U.S. Geological Survey Water-Resources Investigations Report 00-4084, 93 p. [Also available at https://doi.org/10.3133/wri004084.]

Clarke, J.S., Leeth, D.C., Taylor-Harris, D., Painter, J.A., and Labowski, J.L., 2004, Summary of hydraulic properties of the Floridan aquifer system in coastal Georgia and adjacent parts of South Carolina and Florida: U.S. Geological Survey Scientific Investigations Report 2004-5264, 50 p. [Also available at https://doi.org/10.3133/sir20045264.]

Clarke, J.S., Williams, L.J., and Cherry, G.S., 2010, Hydrogeology and water quality of the Floridan aquifer system and effect of Lower Floridan aquifer pumping on the Upper Floridan aquifer at Hunter Army Airfield, Chatham County, Georgia: U.S. Geological Survey Scientific Investigations Report 2010-5080, $56 \mathrm{p}$. [Also available at https://doi.org/10.3133/sir20105080.] de Marsily, G., 1986, Quantitative hydrogeologyGroundwater hydrology for engineers: Orlando, Fla., Academic Press, Inc., 440 p.

Falls, W.F., Baum, J.S., Harrelson, L.G., Brown, L.H., and Jerden, J.L., Jr., 1997, Geology and hydrogeology of Cretaceous and Tertiary strata, and confinement in the vicinity of the U.S. Department of Energy Savannah River Site, South Carolina: U.S. Geological Survey WaterResources Investigations Report 97-4245, 125 p. [Also available at https://doi.org/10.3133/wri974245.]

Falls, W.F., Harrelson, L.G., Conlon, K.J., and Petkewich, M.D., 2005, Hydrogeology, water quality, and water-supply potential of the Lower Floridan aquifer, coastal Georgia 1999-2002: U.S. Geological Survey Scientific Investigations Report 2005-5124, 98 p. [Also available at https://doi.org/10.3133/sir20055124.]

Georgia Environmental Protection Division, 1997, Secondary maximum contaminant levels for drinking waterEnvironmental Rule 391-3-5-.19, amended October 1997: Official Code of Georgia Annotated Statutes, Statute 12-5170 (Georgia Safe Drinking Water Act of 1977) [variously paged].

Harbaugh, A.W., 1990, A computer program for calculating subregional water budgets using results from the U.S. Geological Survey modular three-dimensional finitedifference ground-water flow model: U.S. Geological Survey Open-File Report 90-392, 46 p. [Also available at https://doi.org/10.3133/ofr90392.]

Harbaugh, A.W., Banta, E.R., Hill, M.C., and McDonald, M.G., 2000, MODFLOW-2000, The U.S. Geological Survey modular ground-water model-User guide to modularization concepts and the ground-water flow process: U.S. Geological Survey Open-File Report 2000-92, 121 p. [Also available at https://doi.org/10.3133/ofr200092.]

Jones, L.E., Prowell, D.C., and Maslia, M.L., 2002, Hydrogeology and water quality (1978) of the Floridan aquifer system at U.S. Geological Survey Test Well 26, on Colonels Island, near Brunswick, Georgia: U.S. Geological Survey Water-Resources Investigations Report 02-4020, 44 p. [Also available at https://doi.org/10.3133/wri024020.]

Kellam, M.F., and Gorday, L.L., 1990, Hydrogeology of the Gulf Trough-Apalachicola Embayment area, Georgia: Georgia Geologic Survey Bulletin 94, 73 p.

Kottek, M., Grieser, J., Beck, C., Rudolf, B., and Rubel, F., 2006, World map of the Köppen-Geiger climate classification updated: Meteorologische Zeitschrift, v. 15, no. 3, p. 259-263, accessed September 26, 2013, at https://doi.org/10.1127/0941-2948/2006/0130. 
Krause, R.E., and Randolph, R.B., 1989, Hydrology of the Floridan aquifer system in southeast Georgia and adjacent parts of Florida and South Carolina: U.S. Geological Survey Professional Paper 1403-D, 65 p., 18 pl. [Also available at https://doi.org/10.3133/pp1403D.]

Lawrence, S.J., 2015, Water use in Georgia by county for 2010 and water-use trends, 1985-2010: U.S. Geological Survey Open-File Report 2015-1230, 206 p. [Also available at https://doi.org/10.3133/ofr20151230.]

Leeth, D.C., Peck, M.F., and Painter, J.A., 2007, Groundwater conditions and studies in Georgia, 2004-2005: U.S. Geological Survey Scientific Investigations Report 2007-5017, 299 p. [Also available at https://doi.org/10.3133/sir20075017.]

Maslia, M.L., and Prowell, D.C., 1990, Effects of faults on fluid flow and chloride contamination in a carbonate aquifer system: Journal of Hydrology, v. 115, nos. 1-4, p. 1-49. [Also available at https://doi.org/10.1016/0022-1694(90)90196-5.]

Miller, J.A., 1986, Hydrogeologic framework of the Floridan aquifer system in Florida and in parts of Georgia, Alabama, and South Carolina: U.S. Geological Survey Professional Paper 1403-B, 91 p., 33 pl. [Also available at https://doi.org/10.3133/pp1403B.]

National Oceanic and Atmospheric Administration, 2014, Jacksonville 1981-2010 climate normals: National Weather Service Weather Forecast Office website, accessed April 23, 2014, at http://www.srh.noaa.gov/news/display_cmsstory. php? $w f o=$ jax\&storyid $=71081 \&$ source $=0$.

Paull, C.K., and Dillon, W.P., 1980, Structure, stratigraphy, and geologic history of Florida-Hatteras Shelf and inner Blake Plateau: American Association of Petroleum Geologists Bulletin, v. 64, p. 339-358.

Payne, D.F., Abu Rumman, M., and Clarke, J.S., 2005, Simulation of ground-water flow in coastal Georgia and adjacent parts of South Carolina and FloridaPredevelopment, 1980, and 2000: U.S. Geological Survey Scientific Investigations Report 2005-5089, 91 p. [Also available at https://doi.org/10.3133/sir20055089.]

Peck, M.F., McFadden, K.W., and Leeth, D.C., 2005, Effects of decreased ground-water withdrawal on ground-water levels and chloride concentration in Camden County, Georgia, and ground-water levels in Nassau County, Florida, from September 2001 to May 2003: U.S. Geological Survey Scientific Investigations Report 2004-5295, 36 p. [Also available at https://doi.org/10.3133/sir20045295.]
Pollock, D.W., 1994, User's guide for MODPATH/ MODPATH-PLOT, version 3; a particle tracking post-processing package for MODFLOW, the U.S. Geological Survey finite-difference groundwater flow model: U.S. Geological Survey Open-File Report 94-464 [variously paged]. [Also available at https://doi.org/10.3133/ofr94464.]

Randolph, R.B., Pernik, M., and Garza, R., 1991, Watersupply potential of the Floridan aquifer system in the coastal area of Georgia - A digital model approach: Georgia Geologic Survey Bulletin 116, 30 p.

University of Georgia Weather Network, 2018, Historical data: University of Georgia College of Agricultural \& Environmental Sciences website, accessed on April 3, 2018, at http://www.georgiaweather.net/index.php.

U.S. Census Bureau, 2017, State \& county quickfacts - Glynn County, Georgia: U.S Census Bureau website, accessed April 3, 2018, at https://www.census.gov/quickfacts/fact/ table/glynncountygeorgia/PST045216.

U.S. Environmental Protection Agency, 2000 (revised), Maximum contaminant levels (Part 143, National Secondary Drinking Water Regulations): U.S. Code of Federal Regulations, Title 40, parts 100-149.

Wait, R.L., 1965, Geology and occurrence of fresh and brackish water in Glynn County, Georgia: U.S. Geological Survey Water-Supply Paper 1613-E, 94 p. [Also available at https://doi.org/10.3133/wsp1613E.]

Wait, R.L., and Davis, M.E., 1986, Configuration and hydrology of the pre-Cretaceous rocks underlying the southeastern Coastal Plain aquifer system: U.S. Geological Survey Water-Resources Investigations Report 86-4010, 1 sheet, scale 1:2,000,000. [Also available at https://doi.org/10.3133/wri864010.]

Wait, R.L., and Gregg, D.O., 1973, Hydrology and chloride contamination of the principal artesian aquifer in Glynn County: Georgia Department of Natural Resources Hydrologic Report, 93 p.

Weems, R.E., and Edwards, L.E., 2001, Geology of Oligocene, Miocene, and younger deposits in the coastal area of Georgia: Georgia Geologic Survey Bulletin 131, 124 p. [Also available at https://www2.usgs.gov/water/ southatlantic/ga/publications/ggs/bull-131/.]

Williams, L.J., and Kuniansky, E.L., 2015, Revised hydrogeologic framework of the Floridan aquifer system in Florida and parts of Georgia, Alabama, and South Carolina (ver. 1.1, March 2016): U.S. Geological Survey Professional Paper 1807, 140 p., 23 pls. [Also available at https://doi.org/10.3133/pp1807.] 


\section{Appendix 1. Simulated and Observed Groundwater Levels, 2004 and 2015, for Wells Used in the Simulation of Groundwater Flow in the Brunswick/Glynn County Area of Georgia}

Table 1-1. Simulated and observed groundwater levels, 2004 and 2015.

[Simulated and observed groundwater levels are above or below (-) NAVD 88; observed values for 2004 are during June; observed values for 2015 are during October; see fig. 1-1 for well locations; - , no data]

\begin{tabular}{|c|c|c|c|c|c|c|c|c|c|}
\hline \multirow{3}{*}{$\begin{array}{c}\text { Well } \\
\text { identifier }\end{array}$} & \multirow{3}{*}{$\begin{array}{l}\text { Model } \\
\text { layer }\end{array}$} & \multicolumn{6}{|c|}{ Simulated and observed groundwater levels and difference, in feet } & \multirow{2}{*}{\multicolumn{2}{|c|}{$\begin{array}{c}\text { Water-level change, } \\
\text { in feet, } \\
\text { 2004-2015 }\end{array}$}} \\
\hline & & \multicolumn{3}{|c|}{2004 calibration } & \multicolumn{3}{|c|}{2015 calibration } & & \\
\hline & & Simulated & Observed & Difference & Simulated & Observed & Difference & Simulated & Observed \\
\hline $33 \mathrm{~J} 065$ & 3 & 10.30 & 11.91 & -1.61 & 10.40 & 12.23 & -1.83 & 0.10 & 0.32 \\
\hline $33 \mathrm{G} 028$ & 3 & 8.35 & 21.31 & -12.96 & 7.61 & - & - & -0.74 & - \\
\hline $34 \mathrm{H} 144$ & 3 & 5.40 & 3.60 & 1.80 & 5.89 & 4.08 & 1.81 & 0.49 & 0.48 \\
\hline $34 \mathrm{H} 437$ & 3 & 6.02 & 8.92 & -2.90 & 6.28 & 7.08 & -0.80 & 0.26 & -1.84 \\
\hline 34J077 & 3 & -2.39 & -12.46 & 10.07 & -1.51 & -5.31 & 3.80 & 0.88 & 7.15 \\
\hline 34J081 & 3 & 3.04 & -2.50 & 5.54 & 3.63 & 2.02 & 1.61 & 0.59 & 4.52 \\
\hline $33 \mathrm{~J} 062$ & 5 & 10.30 & 22.09 & -11.79 & 10.50 & 22.98 & -12.48 & 0.20 & 0.89 \\
\hline 34J080 & 5 & 3.06 & 8.55 & -5.49 & 3.64 & 10.68 & -7.04 & 0.58 & 2.13 \\
\hline $33 \mathrm{G} 002$ & 7 & 22.40 & 23.48 & -1.08 & 23.70 & - & - & 1.30 & - \\
\hline 33G008 & 7 & 22.20 & 23.16 & -0.96 & 23.60 & - & - & 1.40 & - \\
\hline $33 \mathrm{G} 024$ & 7 & 24.20 & 29.87 & -5.67 & 25.40 & - & - & 1.20 & - \\
\hline $33 \mathrm{H} 120$ & 7 & 5.48 & 3.08 & 2.40 & 10.30 & 7.98 & 2.32 & 4.82 & 4.90 \\
\hline $33 \mathrm{H} 130$ & 7 & 4.12 & 2.18 & 1.94 & 9.13 & 6.83 & 2.30 & 5.01 & 4.65 \\
\hline 33H133 & 7 & 5.97 & 3.77 & 2.2 & 10.50 & 8.20 & 2.30 & 4.53 & 4.43 \\
\hline $33 \mathrm{H} 177$ & 7 & 23.90 & 28.20 & -4.30 & 25.10 & - & - & 1.20 & - \\
\hline $33 \mathrm{H} 180$ & 7 & 9.20 & 10.10 & -0.90 & 13.00 & 10.10 & 2.90 & 3.80 & 0.00 \\
\hline $33 \mathrm{H} 193$ & 7 & 20.50 & 22.38 & -1.88 & 22.10 & 24.95 & -2.85 & 1.60 & 2.57 \\
\hline $33 \mathrm{H} 207$ & 7 & 9.21 & 8.09 & 1.12 & 12.00 & 13.30 & -1.30 & 2.79 & 5.21 \\
\hline $33 \mathrm{H} 211$ & 7 & -3.16 & -4.16 & 1.00 & 2.58 & - & - & 5.74 & - \\
\hline $33 \mathrm{H} 213$ & 7 & -0.19 & -1.72 & 1.53 & 5.23 & - & - & 5.42 & - \\
\hline $34 \mathrm{G} 002$ & 7 & 17.90 & 22.40 & -4.50 & 20.00 & - & - & 2.10 & - \\
\hline $34 \mathrm{G} 003$ & 7 & 21.60 & 25.90 & -4.30 & 23.00 & - & - & 1.40 & - \\
\hline 34G009 & 7 & 21.30 & 38.70 & -17.40 & 22.50 & 39.77 & -17.27 & 1.20 & 1.07 \\
\hline $34 \mathrm{G} 016$ & 7 & 19.40 & 28.30 & -8.90 & 20.80 & 28.80 & -8.00 & 1.40 & 0.50 \\
\hline 34G017 & 7 & 19.70 & 26.10 & -6.40 & 20.30 & 26.30 & -6.00 & 0.60 & 0.20 \\
\hline $34 \mathrm{G} 020$ & 7 & 20.60 & 30.10 & -9.50 & 21.90 & 31.10 & -9.20 & 1.30 & 1.00 \\
\hline $34 \mathrm{H} 062$ & 7 & 8.54 & - & - & 13.10 & 11.40 & 1.70 & 4.56 & - \\
\hline $34 \mathrm{H} 095$ & 7 & 17.50 & 17.90 & -0.40 & 19.60 & 20.50 & -0.90 & 2.10 & 2.60 \\
\hline $34 \mathrm{H} 112$ & 7 & 12.50 & 12.90 & -0.40 & 15.80 & 15.90 & -0.10 & 3.30 & 3.00 \\
\hline $34 \mathrm{H} 117$ & 7 & 11.80 & 10.50 & 1.30 & 15.20 & - & - & 3.40 & - \\
\hline $34 \mathrm{H} 125$ & 7 & 10.60 & 12.40 & -1.80 & 14.60 & 11.80 & 2.80 & 4.00 & -0.60 \\
\hline $34 \mathrm{H} 128$ & 7 & 9.70 & 8.13 & 1.57 & 13.90 & - & - & 4.20 & - \\
\hline $34 \mathrm{H} 344$ & 7 & 7.68 & 6.22 & 1.46 & 13.20 & - & - & 5.52 & - \\
\hline $34 \mathrm{H} 355$ & 7 & 9.34 & 8.46 & 0.88 & 13.40 & 12.50 & 0.90 & 4.06 & 4.04 \\
\hline
\end{tabular}


Table 1-1. Simulated and observed groundwater levels, 2004 and 2015. - Continued

[Simulated and observed groundwater levels are above or below (-) NAVD 88; observed values for 2004 are during June; observed values for 2015 are during October; see fig. 1-1 for well locations; - - no data]

\begin{tabular}{|c|c|c|c|c|c|c|c|c|c|}
\hline \multirow{3}{*}{$\begin{array}{c}\text { Well } \\
\text { identifier }\end{array}$} & \multirow{3}{*}{$\begin{array}{l}\text { Model } \\
\text { layer }\end{array}$} & \multicolumn{6}{|c|}{ Simulated and observed groundwater levels and difference, in feet } & \multirow{2}{*}{\multicolumn{2}{|c|}{$\begin{array}{c}\text { Water-level change, } \\
\text { in feet, } \\
\text { 2004-2015 }\end{array}$}} \\
\hline & & \multicolumn{3}{|c|}{2004 calibration } & \multicolumn{3}{|c|}{2015 calibration } & & \\
\hline & & Simulated & Observed & Difference & Simulated & Observed & Difference & Simulated & Observed \\
\hline $34 \mathrm{H} 371$ & 7 & 14.30 & 15.50 & -1.20 & 17.20 & 16.20 & 1.00 & 2.90 & 0.70 \\
\hline $34 \mathrm{H} 373$ & 7 & 8.37 & 3.98 & 4.39 & 13.10 & 8.81 & 4.29 & 4.73 & 4.83 \\
\hline $34 \mathrm{H} 374$ & 7 & 7.43 & 7.20 & 0.23 & 11.90 & 10.00 & 1.90 & 4.47 & 2.80 \\
\hline $34 \mathrm{H} 393$ & 7 & 13.80 & 14.60 & -0.80 & 16.80 & 16.70 & 0.10 & 3.00 & 2.10 \\
\hline $34 \mathrm{H} 400$ & 7 & 8.56 & 4.34 & 4.22 & 12.90 & 8.07 & 4.83 & 4.34 & 3.73 \\
\hline $34 \mathrm{H} 401$ & 7 & 7.95 & 2.53 & 5.42 & 12.40 & 6.92 & 5.48 & 4.45 & 4.39 \\
\hline $34 \mathrm{H} 424$ & 7 & 7.86 & - & - & 12.60 & 12.40 & 0.20 & 4.74 & - \\
\hline $34 \mathrm{H} 434$ & 7 & 10.30 & 6.13 & 4.17 & 14.30 & 12.60 & 1.70 & 4 & 6.47 \\
\hline $34 \mathrm{H} 469$ & 7 & 7.48 & 6.61 & 0.87 & 11.90 & 11.50 & 0.40 & 4.42 & 4.89 \\
\hline $34 \mathrm{H} 514$ & 7 & 8.50 & - & - & 13.60 & 12.60 & 1.00 & 5.10 & - \\
\hline $34 \mathrm{H} 552$ & 7 & 8.99 & - & - & 13.30 & 10.40 & 2.90 & 4.31 & - \\
\hline $33 \mathrm{H} 127$ & 9 & 5.98 & 7.85 & -1.87 & 10.60 & 12.80 & -2.20 & 4.62 & 4.95 \\
\hline $33 \mathrm{H} 154$ & 9 & 4.42 & -17.90 & 22.32 & 9.38 & 8.20 & 1.18 & 4.96 & 26.10 \\
\hline 34H334 & 9 & 7.71 & 12.40 & -4.69 & 13.30 & 16.50 & -3.20 & 5.59 & 4.10 \\
\hline $34 \mathrm{H} 402$ & 9 & 7.97 & 8.20 & -0.23 & 12.40 & 10.90 & 1.50 & 4.43 & - \\
\hline $34 \mathrm{H} 403$ & 9 & 14.00 & 16.30 & -2.30 & 17.00 & 17.50 & -0.50 & 3.00 & 1.20 \\
\hline $33 \mathrm{H} 188$ & 11 & 18.70 & 20.10 & -1.40 & 20.60 & - & - & 1.90 & - \\
\hline $33 \mathrm{H} 206$ & 11 & 12.50 & 14.00 & -1.50 & 15.40 & 16.20 & -0.80 & 2.90 & 2.20 \\
\hline 33J044 & 11 & 15.90 & 19.10 & -3.20 & 17.90 & - & - & 2.00 & - \\
\hline 34H391 & 11 & 15.30 & 11.90 & 3.40 & 17.90 & 17.10 & 0.80 & 2.60 & 5.20 \\
\hline $34 \mathrm{H} 436$ & 11 & 13.50 & 15.80 & -2.30 & 16.60 & 19.30 & -2.70 & 3.10 & 3.50 \\
\hline $34 \mathrm{H} 495$ & 11 & 14.50 & 24.00 & -9.50 & 17.30 & 29.50 & -12.20 & 2.80 & 5.50 \\
\hline $34 \mathrm{H} 500$ & 11 & 14.50 & 21.40 & -6.90 & 17.30 & - & - & 2.80 & - \\
\hline
\end{tabular}


A

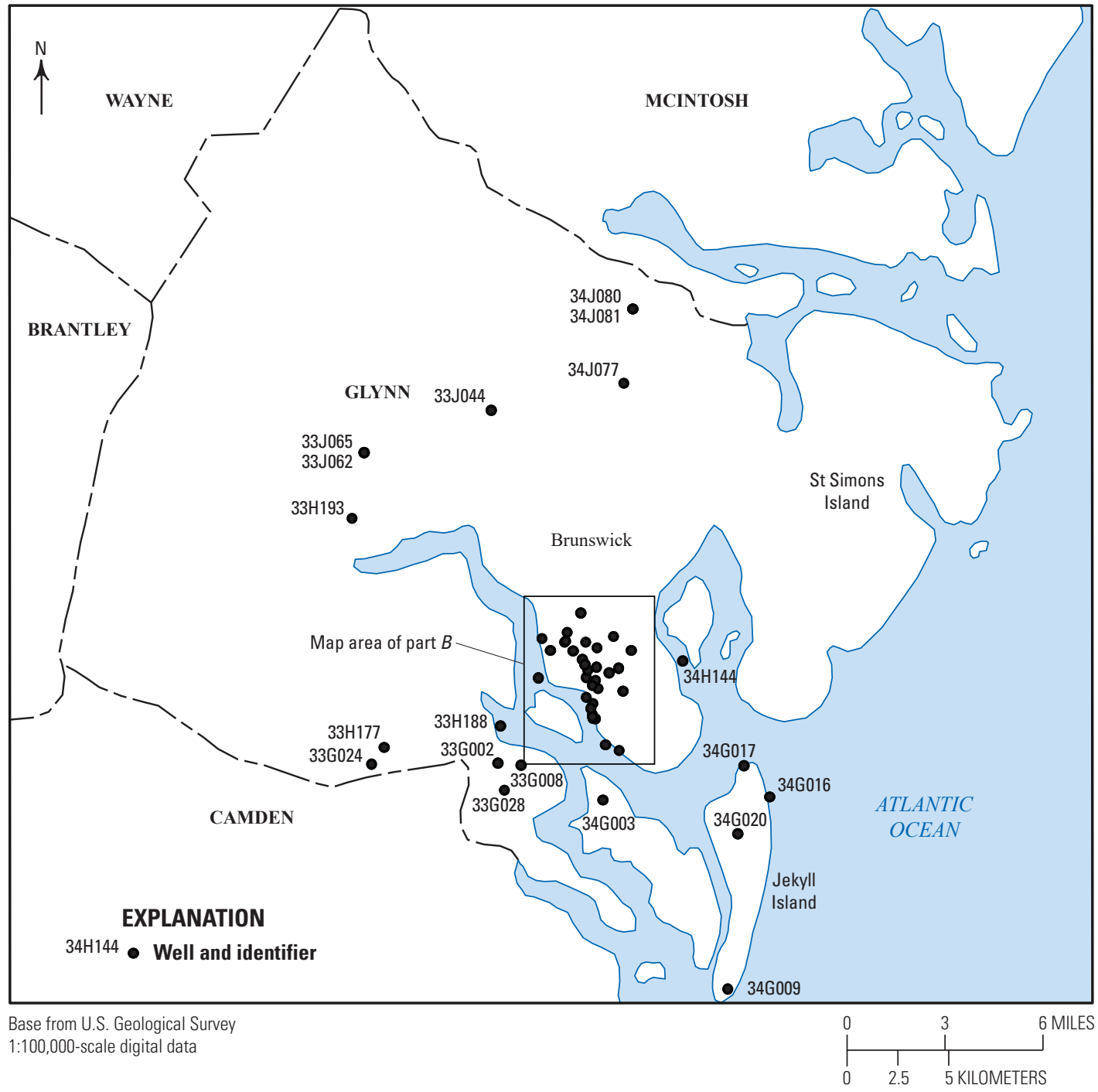

Figure 1-1. Maps showing location of wells used for 2004 and 2015 simulations in (A) Glynn County and (B) Brunswick, Georgia. 
B

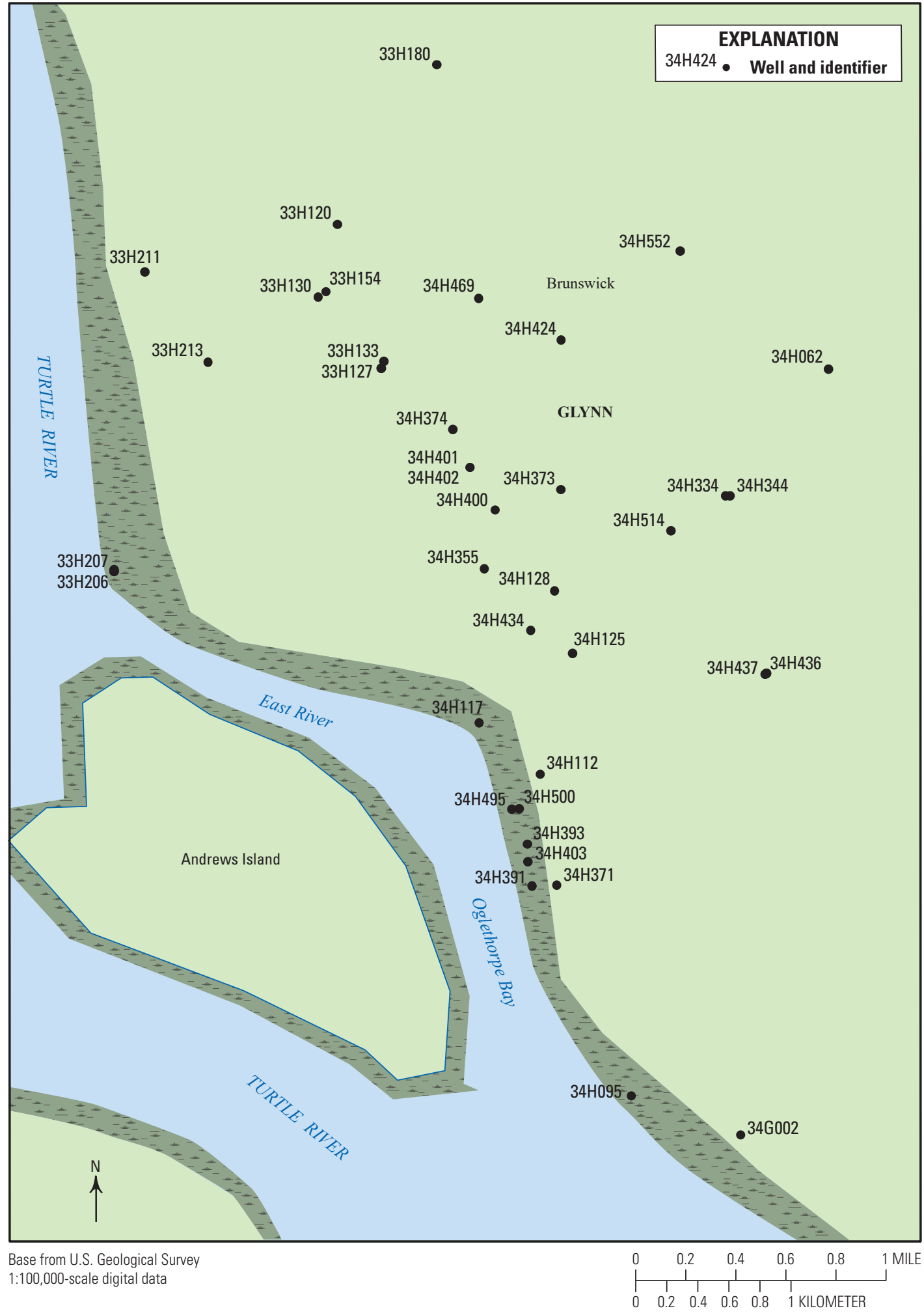

Figure 1-1. -Continued 


\section{Appendix 2. Particle Backtracking Summary for 2015 Base Case and Scenario C Simulations}

Table 2-1. Particle backtracking summary for 2015 Base Case and Scenario C simulations.

[Local z-coordinate where 1.00 represents top of cell and 0 represents bottom; see figure 1 for station locations]

\begin{tabular}{|c|c|c|c|c|c|c|c|c|}
\hline \multirow{2}{*}{$\begin{array}{c}\text { Particle } \\
\text { No. }\end{array}$} & \multicolumn{3}{|c|}{ Model } & \multicolumn{3}{|c|}{ Global coordinate, in feet } & \multirow{2}{*}{$\begin{array}{c}\text { Local } \\
\text { z-coordinate, } \\
\text { in cell }\end{array}$} & \multirow{2}{*}{$\begin{array}{c}\text { Travel } \\
\text { time, } \\
\text { in days }\end{array}$} \\
\hline & Column & Row & Layer & $x$-direction & y-direction & z-direction & & \\
\hline \multicolumn{9}{|c|}{2015 base case, 20 and 50 year } \\
\hline \multicolumn{9}{|c|}{ Well 34H560 } \\
\hline 1 & 247 & 232 & 7 & 860,237 & 425,103 & -649.86 & 0.25 & 0.00 \\
\hline 1 & 249 & 219 & 9 & 861,353 & 431,706 & -720.60 & 0.79 & $7,305.00$ \\
\hline 1 & 250 & 209 & 9 & 861,952 & 436,915 & -730.93 & 0.75 & $18,262.50$ \\
\hline 2 & 247 & 232 & 7 & 860,237 & 425,103 & -578.40 & 0.75 & 0.00 \\
\hline 2 & 248 & 218 & 7 & 861,041 & 432,042 & -603.13 & 0.59 & $7,305.00$ \\
\hline 2 & 249 & 208 & 7 & 861,308 & 437,194 & -609.16 & 0.57 & $18,262.50$ \\
\hline 3 & 247 & 232 & 7 & 860,237 & 425,353 & -649.86 & 0.25 & 0.00 \\
\hline 3 & 250 & 220 & 9 & 861,724 & 431,136 & -691.44 & 0.97 & $7,305.00$ \\
\hline 3 & 252 & 210 & 9 & 862,775 & 436,463 & -702.27 & 0.93 & $18,262.50$ \\
\hline 4 & 247 & 232 & 7 & 860,237 & 425,353 & -578.40 & 0.75 & 0.00 \\
\hline 4 & 250 & 218 & 7 & 861,947 & 432,082 & -591.51 & 0.65 & $7,305.00$ \\
\hline 4 & 252 & 208 & 7 & 862,874 & 436,995 & -599.74 & 0.64 & $18,262.50$ \\
\hline 5 & 247 & 232 & 7 & 860,488 & 425,103 & -649.86 & 0.25 & 0.00 \\
\hline 5 & 255 & 222 & 9 & 864,227 & 430,339 & -700.94 & 0.92 & $7,305.00$ \\
\hline 5 & 261 & 212 & 9 & 867,248 & 434,997 & -715.28 & 0.87 & $18,262.50$ \\
\hline 6 & 247 & 232 & 7 & 860,488 & 425,103 & -578.40 & 0.75 & 0.00 \\
\hline 6 & 255 & 221 & 7 & 864,364 & 430,681 & -588.41 & 0.64 & $7,305.00$ \\
\hline 6 & 261 & 212 & 7 & 867,314 & 435,200 & -599.96 & 0.62 & $18,262.50$ \\
\hline 7 & 247 & 232 & 7 & 860,488 & 425,353 & -649.86 & 0.25 & 0.00 \\
\hline 7 & 252 & 222 & 8 & 862,885 & 430,255 & -685.45 & 0.49 & $7,305.00$ \\
\hline 7 & 256 & 213 & 9 & 864,775 & 434,809 & -697.06 & 0.96 & $18,262.50$ \\
\hline 8 & 247 & 232 & 7 & 860,488 & 425,353 & -578.40 & 0.75 & 0.00 \\
\hline 8 & 253 & 220 & 7 & 863,370 & 431,477 & -585.96 & 0.66 & $7,305.00$ \\
\hline 8 & 257 & 210 & 7 & 865,425 & 436,148 & -595.30 & 0.65 & $18,262.50$ \\
\hline \multicolumn{9}{|c|}{ Well 34H449 } \\
\hline 9 & 257 & 232 & 7 & 865,257 & 425,103 & -650.01 & 0.25 & 0.00 \\
\hline 9 & 263 & 224 & 9 & 868,165 & 429,461 & -738.82 & 0.70 & $7,305.00$ \\
\hline 9 & 273 & 218 & 9 & 873,583 & 432,221 & -755.04 & 0.66 & $18,262.50$ \\
\hline 10 & 257 & 232 & 7 & 865,257 & 425,103 & -571.03 & 0.75 & 0.00 \\
\hline 10 & 262 & 222 & 7 & 867,868 & 430,020 & -599.70 & 0.57 & $7,305.00$ \\
\hline 10 & 272 & 217 & 7 & 872,865 & 432,942 & -615.05 & 0.56 & $18,262.50$ \\
\hline 11 & 257 & 232 & 7 & 865,257 & 425,353 & -650.01 & 0.25 & 0.00 \\
\hline 11 & 263 & 224 & 9 & 868,186 & 429,405 & -698.08 & 0.97 & $7,305.00$ \\
\hline 11 & 273 & 218 & 9 & 873,646 & 432,154 & -715.20 & 0.93 & $18,262.50$ \\
\hline
\end{tabular}


Table 2-1. Particle backtracking summary for 2015 Base Case and Scenario C simulations.-Continued

[Local z-coordinate where 1.00 represents top of cell and 0 represents bottom; see figure 1 for station locations]

\begin{tabular}{|c|c|c|c|c|c|c|c|c|}
\hline \multirow{2}{*}{$\begin{array}{c}\text { Particle } \\
\text { No. }\end{array}$} & \multicolumn{3}{|c|}{ Model } & \multicolumn{3}{|c|}{ Global coordinate, in feet } & \multirow{2}{*}{$\begin{array}{c}\text { Local } \\
\text { z-coordinate, } \\
\text { in cell }\end{array}$} & \multirow{2}{*}{$\begin{array}{l}\text { Travel } \\
\text { time, } \\
\text { in days }\end{array}$} \\
\hline & Column & Row & Layer & x-direction & y-direction & z-direction & & \\
\hline \multicolumn{9}{|c|}{2015 base case, 20 and 50 year-Continued } \\
\hline \multicolumn{9}{|c|}{ Well 34H449-Continued } \\
\hline 12 & 257 & 232 & 7 & 865,257 & 425,353 & -571.03 & 0.75 & 0.00 \\
\hline 12 & 264 & 222 & 7 & 869,056 & 430,104 & -588.47 & 0.65 & $7,305.00$ \\
\hline 12 & 275 & 218 & 7 & 874,432 & 432,357 & -606.29 & 0.64 & $18,262.50$ \\
\hline 13 & 257 & 232 & 7 & 865,508 & 425,103 & -650.01 & 0.25 & 0.00 \\
\hline 13 & 267 & 225 & 9 & 870,501 & 428,552 & -708.08 & 0.94 & $7,305.00$ \\
\hline 13 & 280 & 223 & 9 & 877,080 & 429,827 & -734.29 & 0.88 & $18,262.50$ \\
\hline 14 & 257 & 232 & 7 & 865,508 & 425,103 & -571.03 & 0.75 & 0.00 \\
\hline 14 & 268 & 225 & 7 & 871,001 & 428,834 & -593.15 & 0.64 & $7,305.00$ \\
\hline 14 & 281 & 223 & 7 & 877,509 & 429,881 & -617.48 & 0.62 & $18,262.50$ \\
\hline 15 & 257 & 232 & 7 & 865,508 & 425,353 & -650.01 & 0.25 & 0.00 \\
\hline 15 & 266 & 224 & 8 & 869,967 & 429,356 & -693.19 & 0.91 & $7,305.00$ \\
\hline 15 & 273 & 221 & 9 & 873,402 & 430,699 & -709.64 & 0.97 & $18,262.50$ \\
\hline 16 & 257 & 232 & 7 & 865,508 & 425,353 & -571.03 & 0.75 & 0.00 \\
\hline 16 & 267 & 223 & 7 & 870,252 & 429,514 & -589.06 & 0.66 & $7,305.00$ \\
\hline 16 & 279 & 220 & 7 & 876,232 & 431,074 & -611.25 & 0.65 & $18,262.50$ \\
\hline \multicolumn{9}{|c|}{ Well 34H445 } \\
\hline 17 & 266 & 248 & 7 & 869,776 & 417,102 & -684.77 & 0.25 & 0.00 \\
\hline 17 & 270 & 257 & 7 & 871,826 & 412,662 & -736.03 & 0.02 & $7,305.00$ \\
\hline 17 & 274 & 267 & 7 & 874,065 & 407,529 & -721.04 & 0.13 & $18,262.50$ \\
\hline 18 & 266 & 248 & 7 & 869,776 & 417,102 & -606.10 & 0.75 & 0.00 \\
\hline 18 & 270 & 257 & 7 & 871,826 & 412,662 & -636.01 & 0.67 & $7,305.00$ \\
\hline 18 & 274 & 267 & 7 & 874,065 & 407,529 & -634.86 & 0.70 & $18,262.50$ \\
\hline 19 & 266 & 248 & 7 & 869,776 & 417,352 & -684.77 & 0.25 & 0.00 \\
\hline 19 & 268 & 253 & 9 & 870,781 & 414,721 & -835.21 & 0.49 & $7,305.00$ \\
\hline 19 & 274 & 267 & 7 & 874,097 & 407,645 & -727.84 & 0.08 & $18,262.50$ \\
\hline 20 & 266 & 248 & 7 & 869,776 & 417,352 & -606.10 & 0.75 & 0.00 \\
\hline 20 & 267 & 255 & 7 & 870,206 & 413,715 & -657.38 & 0.52 & $7,305.00$ \\
\hline 20 & 274 & 267 & 7 & 874,097 & 407,645 & -637.12 & 0.69 & $18,262.50$ \\
\hline 21 & 266 & 248 & 7 & 870,027 & 417,102 & -684.77 & 0.25 & 0.00 \\
\hline 21 & 272 & 256 & 7 & 872,890 & 413,329 & -728.35 & 0.06 & $7,305.00$ \\
\hline 21 & 275 & 267 & 7 & 874,560 & 407,895 & -717.93 & 0.14 & $18,262.50$ \\
\hline 22 & 266 & 248 & 7 & 870,027 & 417,102 & -606.10 & 0.75 & 0.00 \\
\hline 22 & 272 & 256 & 7 & 872,890 & 413,329 & -632.26 & 0.69 & $7,305.00$ \\
\hline 22 & 275 & 267 & 7 & 874,560 & 407,895 & -633.34 & 0.71 & $18,262.50$ \\
\hline 23 & 266 & 248 & 7 & 870,027 & 417,352 & -684.77 & 0.25 & 0.00 \\
\hline 23 & 270 & 250 & 8 & 872,153 & 416,132 & -733.23 & 0.86 & $7,305.00$ \\
\hline 23 & 276 & 266 & 7 & 874,734 & 408,158 & -721.90 & 0.11 & $18,262.50$ \\
\hline 24 & 266 & 248 & 7 & 870,027 & 417,352 & -606.10 & 0.75 & 0.00 \\
\hline 24 & 273 & 254 & 7 & 873,644 & 414,464 & -633.04 & 0.67 & $7,305.00$ \\
\hline 24 & 276 & 266 & 7 & 874,734 & 408,158 & -633.91 & 0.70 & $18,262.50$ \\
\hline
\end{tabular}


Table 2-1. Particle backtracking summary for 2015 Base Case and Scenario C simulations. - Continued

[Local z-coordinate where 1.00 represents top of cell and 0 represents bottom; see figure 1 for station locations]

\begin{tabular}{|c|c|c|c|c|c|c|c|c|}
\hline \multirow{2}{*}{$\begin{array}{c}\text { Particle } \\
\text { No. }\end{array}$} & \multicolumn{3}{|c|}{ Model } & \multicolumn{3}{|c|}{ Global coordinate, in feet } & \multirow{2}{*}{$\begin{array}{c}\text { Local } \\
\text { z-coordinate, } \\
\text { in cell }\end{array}$} & \multirow{2}{*}{$\begin{array}{l}\text { Travel } \\
\text { time, } \\
\text { in days }\end{array}$} \\
\hline & Column & Row & Layer & x-direction & y-direction & z-direction & & \\
\hline \multicolumn{9}{|c|}{ Scenario C, 20 and 50 year } \\
\hline \multicolumn{9}{|c|}{ Well 34H560 } \\
\hline 1 & 247 & 232 & 7 & 860,237 & 425,103 & -649.86 & 0.25 & 0.00 \\
\hline 1 & 243 & 236 & 9 & 858,348 & 423,236 & -728.54 & 0.77 & $7,305.00$ \\
\hline 1 & 240 & 241 & 9 & 856,662 & 420,910 & -744.89 & 0.69 & $18,262.50$ \\
\hline 2 & 247 & 232 & 7 & 860,237 & 425,103 & -578.40 & 0.75 & 0.00 \\
\hline 2 & 242 & 237 & 7 & 858,065 & 422,883 & -611.42 & 0.58 & $7,305.00$ \\
\hline 2 & 239 & 242 & 7 & 856,212 & 420,346 & -622.20 & 0.55 & $18,262.50$ \\
\hline 3 & 247 & 232 & 7 & 860,237 & 425,353 & -649.86 & 0.25 & 0.00 \\
\hline 3 & 240 & 233 & 9 & 856,674 & 424,685 & -722.52 & 0.79 & $7,305.00$ \\
\hline 3 & 236 & 238 & 9 & 854,920 & 422,443 & -739.25 & 0.71 & $18,262.50$ \\
\hline 4 & 247 & 232 & 7 & 860,237 & 425,353 & -578.40 & 0.75 & 0.00 \\
\hline 4 & 239 & 233 & 7 & 856,273 & 424,646 & -611.61 & 0.59 & $7,305.00$ \\
\hline 4 & 235 & 238 & 7 & 854,333 & 422,164 & -623.93 & 0.55 & $18,262.50$ \\
\hline 5 & 247 & 232 & 7 & 860,488 & 425,103 & -649.86 & 0.25 & 0.00 \\
\hline 5 & 247 & 236 & 9 & 860,252 & 423,005 & -757.21 & 0.58 & $7,305.00$ \\
\hline 5 & 244 & 241 & 9 & 858,798 & 420,527 & -774.40 & 0.51 & $18,262.50$ \\
\hline 6 & 247 & 232 & 7 & 860,488 & 425,103 & -578.40 & 0.75 & 0.00 \\
\hline 6 & 247 & 238 & 7 & 860,340 & 422,426 & -615.00 & 0.53 & $7,305.00$ \\
\hline 6 & 244 & 243 & 7 & 858,757 & 419,763 & -625.72 & 0.49 & $18,262.50$ \\
\hline 7 & 247 & 232 & 7 & 860,488 & 425,353 & -649.86 & 0.25 & 0.00 \\
\hline 7 & 243 & 231 & 9 & 858,174 & 425,830 & -774.47 & 0.44 & $7,305.00$ \\
\hline 7 & 236 & 235 & 9 & 855,022 & 423,673 & -796.96 & 0.33 & $18,262.50$ \\
\hline 8 & 247 & 232 & 7 & 860,488 & 425,353 & -578.40 & 0.75 & 0.00 \\
\hline 8 & 243 & 228 & 7 & 858,554 & 427,061 & -627.52 & 0.42 & $7,305.00$ \\
\hline 8 & 234 & 233 & 7 & 853,681 & 424,931 & -649.22 & 0.32 & $18,262.50$ \\
\hline \multicolumn{9}{|c|}{ Well 34H449 } \\
\hline 9 & 257 & 232 & 7 & 865,257 & 425,103 & -650.01 & 0.25 & 0.00 \\
\hline 9 & 254 & 235 & 9 & 863,939 & 423,821 & -731.31 & 0.76 & $7,305.00$ \\
\hline 9 & 253 & 238 & 9 & 863,153 & 422,001 & -750.67 & 0.66 & $18,262.50$ \\
\hline 10 & 257 & 232 & 7 & 865,257 & 425,103 & -571.03 & 0.75 & 0.00 \\
\hline 10 & 254 & 236 & 7 & 863,704 & 423,418 & -599.84 & 0.59 & $7,305.00$ \\
\hline 10 & 252 & 240 & 7 & 862,758 & 421,246 & -610.28 & 0.55 & $18,262.50$ \\
\hline 11 & 257 & 232 & 7 & 865,257 & 425,353 & -650.01 & 0.25 & 0.00 \\
\hline 11 & 252 & 231 & 9 & 862,965 & 425,620 & -740.90 & 0.66 & $7,305.00$ \\
\hline 11 & 250 & 235 & 9 & 861,638 & 423,662 & -795.42 & 0.34 & $18,262.50$ \\
\hline 12 & 257 & 232 & 7 & 865,257 & 425,353 & -571.03 & 0.75 & 0.00 \\
\hline 12 & 252 & 231 & 7 & 862,720 & 425,936 & -603.92 & 0.54 & $7,305.00$ \\
\hline 12 & 250 & 232 & 9 & 862,028 & 425,038 & -691.01 & 0.99 & $18,262.50$ \\
\hline
\end{tabular}


Table 2-1. Particle backtracking summary for 2015 Base Case and Scenario C simulations.-Continued

[Local z-coordinate where 1.00 represents top of cell and 0 represents bottom; see figure 1 for station locations]

\begin{tabular}{|c|c|c|c|c|c|c|c|c|}
\hline \multirow{2}{*}{$\begin{array}{c}\text { Particle } \\
\text { No. }\end{array}$} & \multicolumn{3}{|c|}{ Model } & \multicolumn{3}{|c|}{ Global coordinate, in feet } & \multirow{2}{*}{$\begin{array}{l}\text { Local } \\
\text { z-coordinate, } \\
\text { in cell }\end{array}$} & \multirow{2}{*}{$\begin{array}{l}\text { Travel } \\
\text { time, } \\
\text { in days }\end{array}$} \\
\hline & Column & Row & Layer & $x$-direction & y-direction & z-direction & & \\
\hline \multicolumn{9}{|c|}{ Scenario C, 20 and 50 year-Continued } \\
\hline \multicolumn{9}{|c|}{ Well 34H449-Continued } \\
\hline 13 & 257 & 232 & 7 & 865,508 & 425,103 & -650.01 & 0.25 & 0.00 \\
\hline 13 & 259 & 234 & 9 & 866,630 & 424,225 & -769.10 & 0.54 & $7,305.00$ \\
\hline 13 & 259 & 237 & 9 & 866,559 & 422,579 & -796.07 & 0.40 & $18,262.50$ \\
\hline 14 & 257 & 232 & 7 & 865,508 & 425,103 & -571.03 & 0.75 & 0.00 \\
\hline 14 & 260 & 235 & 7 & 866,971 & 423,792 & -607.48 & 0.55 & $7,305.00$ \\
\hline 14 & 260 & 239 & 7 & 866,776 & 421,847 & -622.16 & 0.49 & $18,262.50$ \\
\hline 15 & 257 & 232 & 7 & 865,508 & 425,353 & -650.01 & 0.25 & 0.00 \\
\hline 15 & 257 & 230 & 9 & 865,625 & 426,396 & -768.73 & 0.49 & $7,305.00$ \\
\hline 15 & 254 & 229 & 9 & 864,039 & 426,782 & -817.22 & 0.16 & $18,262.50$ \\
\hline 16 & 257 & 232 & 7 & 865,508 & 425,353 & -571.03 & 0.75 & 0.00 \\
\hline 16 & 258 & 228 & 7 & 865,984 & 427,282 & -607.06 & 0.51 & $7,305.00$ \\
\hline 16 & 256 & 226 & 7 & 864,917 & 428,016 & -633.94 & 0.33 & $18,262.50$ \\
\hline \multicolumn{9}{|c|}{ Well 34H445 } \\
\hline 17 & 266 & 248 & 7 & 869,776 & 417,102 & -684.77 & 0.25 & 0.00 \\
\hline 17 & 264 & 252 & 9 & 868,679 & 415,233 & -766.54 & 0.83 & $7,305.00$ \\
\hline 17 & 262 & 256 & 9 & 867,781 & 413,393 & -775.21 & 0.82 & $18,262.50$ \\
\hline 18 & 266 & 248 & 7 & 869,776 & 417,102 & -606.10 & 0.75 & 0.00 \\
\hline 18 & 263 & 253 & 7 & 868,382 & 414,703 & -636.17 & 0.61 & $7,305.00$ \\
\hline 18 & 261 & 258 & 7 & 867,465 & 412,449 & -643.60 & 0.62 & $18,262.50$ \\
\hline 19 & 266 & 248 & 7 & 869,776 & 417,352 & -684.77 & 0.25 & 0.00 \\
\hline 19 & 263 & 249 & 9 & 868,313 & 416,948 & -792.86 & 0.63 & $7,305.00$ \\
\hline 19 & 260 & 252 & 9 & 867,048 & 415,155 & -817.15 & 0.52 & $18,262.50$ \\
\hline 20 & 266 & 248 & 7 & 869,776 & 417,352 & -606.10 & 0.75 & 0.00 \\
\hline 20 & 261 & 249 & 7 & 867,614 & 416,906 & -636.12 & 0.54 & $7,305.00$ \\
\hline 20 & 259 & 253 & 7 & 866,141 & 414,808 & -650.68 & 0.50 & $18,262.50$ \\
\hline 21 & 266 & 248 & 7 & 870,027 & 417,102 & -684.77 & 0.25 & 0.00 \\
\hline 21 & 267 & 252 & 9 & 870,388 & 415,184 & -772.28 & 0.82 & $7,305.00$ \\
\hline 21 & 267 & 255 & 9 & 870,278 & 413,587 & -783.88 & 0.78 & $18,262.50$ \\
\hline 22 & 266 & 248 & 7 & 870,027 & 417,102 & -606.10 & 0.75 & 0.00 \\
\hline 22 & 267 & 253 & 7 & 870,560 & 414,511 & -640.03 & 0.61 & $7,305.00$ \\
\hline 22 & 267 & 258 & 7 & 870,354 & 412,309 & -648.82 & 0.60 & $18,262.50$ \\
\hline 23 & 266 & 248 & 7 & 870,027 & 417,352 & -684.77 & 0.25 & 0.00 \\
\hline 23 & 268 & 248 & 9 & 870,963 & 417,125 & -823.71 & 0.48 & $7,305.00$ \\
\hline 23 & 269 & 251 & 9 & 871,464 & 415,569 & -865.48 & 0.30 & $18,262.50$ \\
\hline 24 & 266 & 248 & 7 & 870,027 & 417,352 & -606.10 & 0.75 & 0.00 \\
\hline 24 & 270 & 248 & 7 & 871,730 & 417,377 & -651.30 & 0.50 & $7,305.00$ \\
\hline 24 & 272 & 251 & 7 & 872,694 & 415,601 & -665.40 & 0.45 & $18,262.50$ \\
\hline
\end{tabular}


For more information concerning the research in this report, contact South Atlantic Water Science Center

U.S. Geological Survey

720 Gracern Road, Suite 129

Columbia, SC 29210

Or visit the South Atlantic Water Science Center website at https://www.usgs.gov/centers/sa-water/

Publishing support provided by the U.S. Geological Survey Science Publishing Network, Reston and Sacramento 


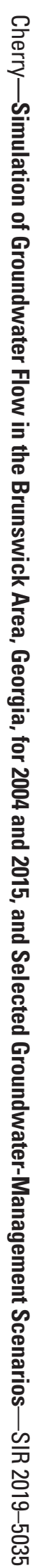

